\title{
VALOR ALIMENTAR DO CAPIM TANZÂNIA IRRIGADO
}

\author{
Marco Antonio Alvares Balsalobre
}

Tese apresentada à Escola Superior de Agricultura "Luiz de Queiroz", Universidade de São Paulo, para obtenção do título de Doutor em Agronomia, Área de Concentração: Ciência Animal e Pastagens.

PIRACICABA

Estado de São Paulo - Brasil

Janeiro - 2002 


\section{VALOR ALIMENTAR DO CAPIM TANZÂNIA IRRIGADO}

\section{Marco Antonio Alvares Balsalobre}

Engenheiro Agrônomo

Orientador: Prof. Dr. MOACYR CORSI

Tese apresentada à Escola Superior de Agricultura "Luiz de Queiroz", Universidade de São Paulo, para obtenção do título de Doutor em Agronomia, Área de Concentração: Ciência Animal e Pastagens.

PIRACICABA

Estado de São Paulo - Brasil

Janeiro - 2002 
Dados Internacionais de Catalogação na Publicação (CIP) DIVSÃO DE BIBLIOTECA E DOCUMENTAÇÃO - ESALQ/USP

Balsalobre, Marco Antonio Alva res

Valor alimentar do capim Tanzânia imiga do / Marco Antonio Alvares Balsalobre. - - Piracicaba, 2002.

$113 \mathrm{p}$.

Tese (doutorado) - Escola Superior de Agricultura Luiz de Queiroz, 2002. Bibliografia.

1. Bromatologia 2. Capim colonião 3. Imigação 4. Va lor nutritivo I. Título

CDD 633.2

“Permitida a cópia total ou parcial deste documento, desde que citada a fonte - O autor” 
Aos professores

Vidal Pedroso de Faria

e Moacyr Corsi

Dedico 


\section{AGRADECIMENTOS}

- Eng ${ }^{\mathrm{a}}$. Agr ${ }^{\mathrm{a}}$. Patrícia Menezes Santos, pelo difícil trabalho de ajuda, animação e paciência principalmente nos momentos mais difíceis passados durante a condução dos trabalhos.

- Professor Dr. Moacyr Corsi pelo incentivo constante

- Eng. Agr. Marco Antonio Penati pelo companheirismo e sugestões para a melhor condução desse trabalho.

- Eng. Agr. Daniel da Silva Pagotto pelo auxílio na condução do experimento e organização dos estagiários.

- Eng. Agr. Ivan Vieira pela ajuda nas análises bromatológicas e pela amizade.

- Estagiários do projeto CAPIM que auxiliaram na condução dos trabalhos.

- Professora $\operatorname{Dr}^{\mathrm{a}}$ Clarice Garcia Borges Demétrio pelo auxilio e execução das análises estatísticas.

- Aluno de mestrado em Estatística Experimental e Agronômica Ramiro Ruiz Cárdenas pela execução das análises estatísticas.

- Dr. Virgílio Franco do Nascimento Filho, pesquisador do CENA/USP, pelas determinações de cromo.

- Carlos César Alves, técnico do laboratório de Bromatologia da ESALQ/USP. 


\section{SUMÁRIO}

\begin{tabular}{|c|c|}
\hline \multicolumn{2}{|l|}{ 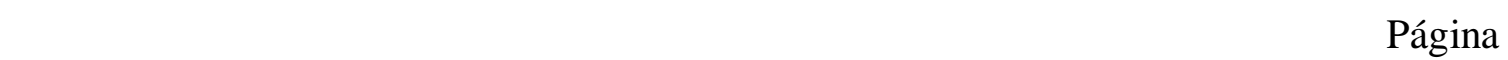 } \\
\hline 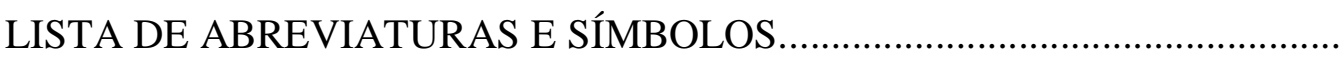 & vii \\
\hline RESUMO. & $\mathrm{x}$ \\
\hline SUMMARY. & \\
\hline 1 INTRODUÇÃO.. & \\
\hline 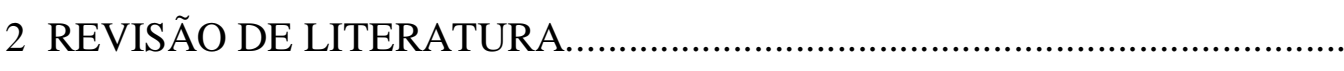 & \\
\hline 2.1 Qualidade bromatológica............. & \\
\hline 2.2 Carboidrato........... & \\
\hline 2.3 Proteína..... & \\
\hline 2.4 Qualidade e estresse hídrico... & \\
\hline 2.5 Degradações das frações carboidratos e protéicas..... & \\
\hline 6 Resíduo pós-pastejo. & \\
\hline
\end{tabular}

3 AVALIAÇÃO DA QUALIDADE NUTRICIONAL DO CAPIM TANZÂNIA PASTEJADO EM ÁREA IRRIGADA SOB TRÊS NÍVEIS DE RESÍDUO PÓS- PASTEJO....................................................................... 26

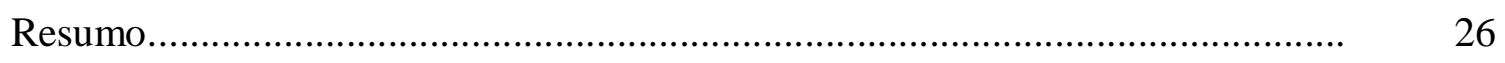

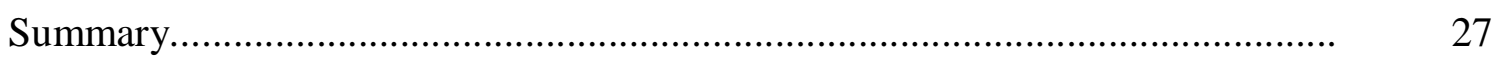

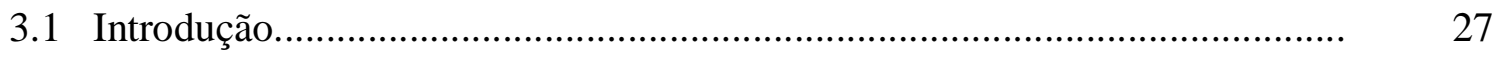


3.2 Material e Métodos...................................................................................... 31

3.3 Resultados e Discussão.............................................................................. 35

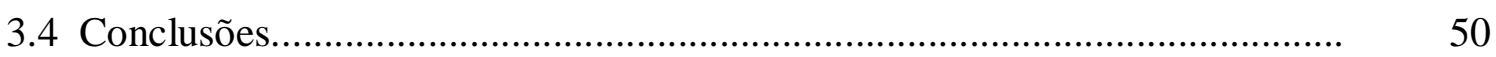

4 CINÉTICA DA DEGRADAÇÃO RUMINAL DE AMOSTRAS DE PASTEJO SIMULADO DE CAPIM TANZÂNIA, PASTEJADO SOB TRÊS NÍVEIS DE RESÍDUO PÓS-PASTEJO, COLHIDAS NAS ESTAÇÕES DE VERÃO, OUTONO E PRIMAVERA................................................................. 51

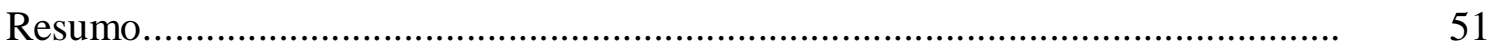

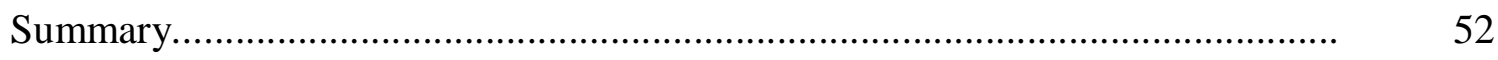

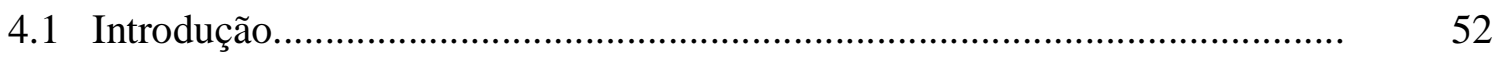

4.2 Material e Métodos................................................................................... 56

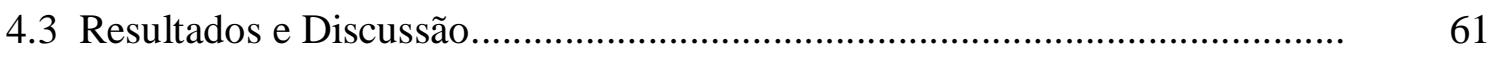

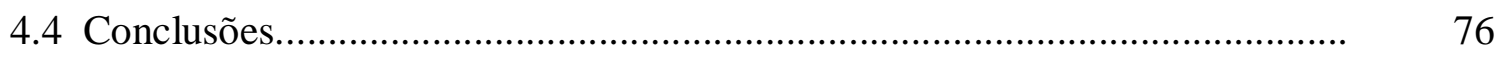

5 CONSUMO DE FORRAGEM POR ANIMAIS NELORE EM CRESCIMENTO EM PASTAGENS DE CAPIM TANZÂNIA IRRIGADO SOB TRÊS RESÍDUOS PÓS-PASTEJO..............................................................

Resumo ...........................................................................................

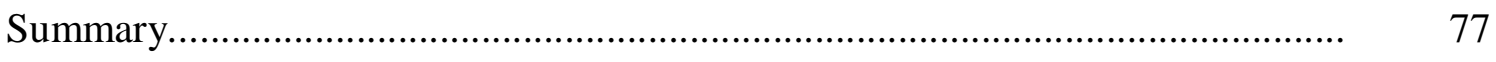

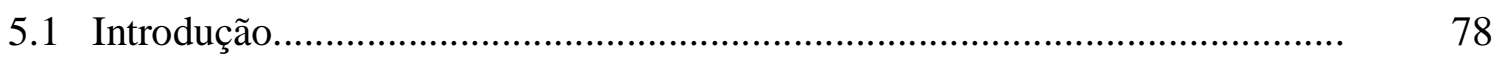

5.2 Material e Métodos........................................................................................ 81

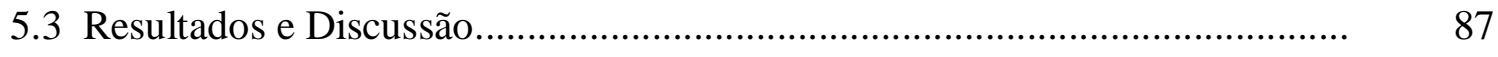

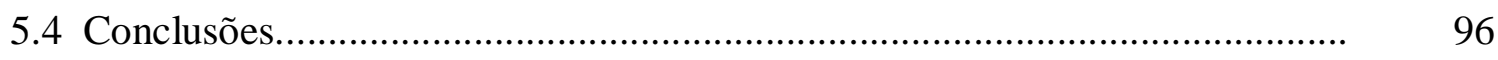

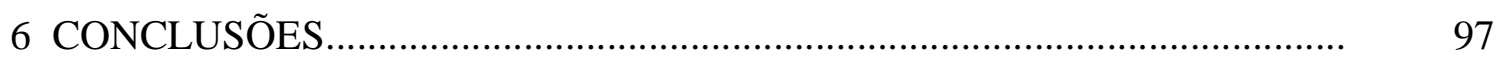

REFERÊNCIAS BIBLIOGRÁFICAS............................................................ 100 


\section{LISTA DE ABREVIATURAS E SÍMBOLOS}

c - Taxa de degradação

CE - Carboidrato estrutural

CNCPS - Cornell net carbohydrate protein system

$\mathrm{CNE}$ - Carboidrato não estrutural

CT - Carboidratos totais

CTC - Capacidade de troca de cátions

DE - Degradação efetiva

DP - Degradação potencial

DIVMS - Digestibilidade in vitro da matéria seca

FDA - Fibra em detergente ácido

FDN - Fibra em detergente neutro

FDND - Fibra em detergente neutro digestível

FDNi - Fibra em detergente neutro indigestível

Fração A carboidratos - Açucares solúveis

Fração B1 carboidratos - Amido

Fração B2 carboidratos - Fração potencialmente degradável da parede celular

Fração C carboidratos - Fração indegradável

Fração A proteína - nitrogênio não protéico

Fração B1 proteína - proteína verdadeira de rápida degradação

Fração B2 proteína - proteína solúvel de degradação média 
Fração B3 proteína - proteína aderida à parede celular de lenta degradação

Fração A - Porção solúvel no rúmen

Fração B - Porção potencialmente degradável no rúmen

Fração C - Porção indegradável no rúmen

Lag time - Tempo para início da degradação da fração B

nFDA - Nitrogênio aderido à FDA

nFDN - Nitrogênio aderido à FDN

MM - Matéria mineral

MO - Matéria orgânica

MOAD - Matéria orgânica aparente degradável

MOD - Matéria orgânica degradável

NDT - Nutrientes digestíveis totais

$\mathrm{NnP}$ - Nitrogênio não protéico

Nsol - Nitrogênio solúvel

PDR - Proteína degradável no rúmen

PB - Proteína bruta

RPD - Resíduo potencialmente degradável 


\title{
VALOR ALIMENTAR DO CAPIM TANZÂNIA IRRIGADO
}

\author{
Autor: MARCO ANTONIO ALVARES BALSALOBRE \\ Orientador: Prof. Dr. Moacyr Corsi
}

\section{RESUMO}

Amostras simulando o pastejo de capim Tanzânia (Panicum maximum Jacq.) irrigado sob três resíduo pós-pastejo $(\mathrm{T} 1=$ baixo; $\mathrm{T} 2=$ médio; $\mathrm{T} 3=$ alto $)$ foram coletadas durante um ano e analisadas para a determinação da composição protéica e dos carboidratos, e das frações protéicas e carboidratos (CNCPS). O teor de NDT também foi estimado. Nos períodos de verão, outono e primavera, foi avaliado a degradação ruminal da MS, FDN, FDA, PB e nFDN das amostras de pastejo simulado. Nestes períodos, também foi estimado o consumo de forragem usando-se o óxido de cromo como marcador. Não houve diferença de qualidade nutricional entre os tratamentos. Os maiores teores de FDN (68,3 a 64,5\%) e FDA (34,89 a 33,18\%) ocorreram no período de primavera/verão. A lignina apresentou maiores proporções no inverno $(4,68$ a 4,10), provocando variação na fração $\mathrm{C}$ dos carboidratos (14,14 a 23,21 \%CT). O NDT variou entre 55,26 e 59,31\%. O teor de PB teve tendência de aumento ao longo do ano, variando de 11,29 a $14,61 \%$. Os teores de $\mathrm{NnP}$ variaram entre 18,23 e $28,77 \% \mathrm{~PB}$, sendo menores durante a primavera/verão. O Nsol variou de 24,97 a 35,97 \%PB. A fração nFDN foi, em média, de 49,11 \%PB. Para o nFDA, a variação foi de 6,48 e 11,94 \%PB. A avaliação da degradação ruminal indica que as maiores taxas de degradações e 
menores frações indisponíveis ocorreram no período de verão. O T1 foi o tratamento que apresentou maior redução de digestibilidade entre o verão $(81,41 \%)$ e a primavera (74,96\%). A fração prontamente solúvel da proteína pode ser maior que $40 \%$ da PDR, que variou entre 76,36 \% PB (verão) e 62,05 \% PB (primavera). A fração indigestível da FDN (C) é maior que a estimada pelo CNCPS a partir dos teores de lignina/FDN multiplicados por 2,4. Os resultados deste trabalho indicam que o fator de multiplicação deve estar entre 2,91 e 3,35. A fração $\mathrm{C}$ do $\mathrm{nFDN}(12,11$ a 17,08\%) é maior que a calculada em laboratório como sendo nFDA (6,48 a 10,7\%). Quanto maior o teor de PB e de nFDN, pior foi a digestibilidade da PB. A menor qualidade da planta no período entre julho e setembro pode estar relacionada à menor renovação de tecidos durante o período de inverno e ao acúmulo de perfilhos florescidos. O consumo de forragem foi menor para o T1 (65,8 g/kg PM) e para o período de primavera $(61,3 \mathrm{~g} / \mathrm{kg} \mathrm{PM})$. Em média, o consumo de FDN foi de 1,34\% do peso animal. A altura do resíduo póspastejo, a oferta de folhas e a MSD explicaram, em média, 50\% do consumo de forragem nas três estações do ano. No período do verão, houve aumento no consumo de forragem com o aumento da altura de pastejo e da oferta de folhas. Ainda no período de verão, o consumo máximo de forragem $(82,98 \mathrm{~g} / \mathrm{kg} \mathrm{PM})$ foi obtido com um resíduo de $2833 \mathrm{~kg} \mathrm{MSV/ha.} \mathrm{A} \mathrm{relação} \mathrm{PDR/MDOR} \mathrm{foi,} \mathrm{entre} \mathrm{15,02} \mathrm{e} \mathrm{19,18 \% ,} \mathrm{gerando} \mathrm{um}$ excesso de $\mathrm{N}$ ruminal entre 4 e $29 \%$. 


\title{
FORAGE QUALITY OF IRRIGATED TANZÂNIA GRASS
}

\author{
Author: MARCO ANTONIO ALVARES BALSALOBRE \\ Adviser: Prof. Dr. Moacyr Corsi
}

\section{SUMMARY}

The objective of this work was to: determine the chemical composition; study DM, NDF, CP and nNDF ruminal kinectics; estimate forage intake by Nellore growing steers of irrigated Tanzania grass (Panicum maximum Jacq.); and validate the Cornell system. Simulated-grazed samples were collected on three periods of the year (spring, summer and fall, totaling 10 grazing cycles) on irrigated paddocks, rotationally grazed to three post grazing green dry matter residues $(\mathrm{T} 1=$ low, $\mathrm{T} 2=$ medium and T3 $=$ high). Three rumen cannulated animals were used in a $3 \times 3$ Latin square design to determine the in situ degradability up to 96 hours of incubation. NDF, CP and nNDF were determined through NIRS in the residue remaining in the bags. Although there were no statistical differences imposed by the treatments during the year, the NDF and ADF showed higher values $(\mathrm{P}<.05)$ in the spring/summer, and lignin in the winter $(\mathrm{P}$ $<.05)$ grazing cycles. Along the year the carbohydrate $\mathrm{C}$ fraction, TDN and CP varied from 14.14 to $23.21 \%$, 55.26 to $59.31 \%$ and 11.29 to $14.61 \%$, respectively. The Nsol, NNP and nADF (as CP\%) varied from 18.23 to $28.77 \%, 24.97$ to $35.97 \%$ and $6.48 \%$ to $11.94 \%$, respectively. The average $\mathrm{nFDN}$ (as CP\%) was $49.11 \%$. From July to September forage quality was the lowest, probably due to the slowest tissue 
replenishment and flowering tillers' accumulation. The $\mathrm{N}$ largest proportion (average of $40 \%$ of the $\mathrm{CP}$ fraction) was recovered in the cell wall, specifically in the B3 fraction, which should be the most important fraction on ruminal fermentation kinetics studies. Forage quality was the highest in the summer. The low post grazing residue treatment showed the largest increase in digestibility in all fractions from spring $(74.96 \%)$ to summer $(81.41 \%)$. The soluble protein fraction showed values up to $40 \%$ of the RDP, which varied from 62 to $76 \%$ of the $\mathrm{CP}$. The NDF C fraction was underestimated by the CNCPS; our data suggests the \%lignin/\% NDF should be multiplied by a factor between 2.91 and 3.35. The CNCPS overestimated the nNDF C fraction (12.11 to $17.08 \%$ ) as compared to the wet lab analysis value, as regarded to be the nADF fraction (6.48 to $10.7 \%$ ). In general our results showed that the CP digestibility decreased as the $\mathrm{CP}$ and nNDF contents increased. The low post grazing residue and the spring time showed the lowest forage intake ( 65.8 and $61.3 \mathrm{~g} / \mathrm{kg}$ PM, respectively). On the average the NDF intake was $1.34 \%$ of live weight. The post grazing height, leaf allowance and digestible dry matter explained $50 \%$ of forage intake. The forage intake increased as both the post grazing and leaf allowance increased during the summer. The estimated maximum forage intake $(82.98 \mathrm{~g} / \mathrm{kg} \mathrm{PM})$ during the summer was obtained with a post-grazing residue of $2,833 \mathrm{~kg} / \mathrm{ha}$ of GDMR. The estimated range of RDP/RDOM ratio was from 15.02 to 19.18 , which indicates an excess of rumen nitrogen of 4 to $29 \%$. Overall the forage intake was overestimated in 3.8 to $55 \%$ by the CNCPS. 


\section{INTRODUÇÃO}

A determinação da composição bromatológica e da digestibilidade das frações que compõem a planta forrageira é de fundamental importância para a previsão do desempenho animal em sistemas de produção de bovinos.

Com o surgimento e evolução do programa nutricional da Universidade de Cornell, o CNCPS (Cornell Net Carbohydrate and Protein System) (Sniffen et al., 1992; Russel et al., 1992; Fox et al., 1992), uma nova forma de se prever o desempenho de bovinos foi adotada. Até então, os programas de predição de desempenho eram estáticos, não levando em consideração os vários componentes do alimento com suas diferentes taxas de degradação ruminal e suas interações. O programa de Cornell, como é conhecido, tenta ser um sistema dinâmico, adotando taxas de passagem e taxas de degradações diferenciadas para cada fração da proteína e dos carboidratos.

O programa de Cornell, sendo um programa de simulação, tem duas funções: a primeira, seu objetivo principal, é prever o desempenho animal; a outra é indicar novas pesquisas em assuntos que ainda não estão bem definidos.

As plantas forrageiras tropicais, como é o caso do capim Tanzânia (Panicum maximum Jacq.), precisam ser melhor avaliadas em relação às suas qualidades nutricionais, principalmente no tocante à composição bromatológica mais detalhada e as determinações das taxas de degradação de suas frações. Devido às variações na condição climática e no estágio de desenvolvimento do capim Tanzânia, o estudo da qualidade da planta ao longo das estações do ano também se faz necessário.

Na busca por maiores taxas de lucro, alguns sistemas de produção pecuário

passaram a adotar a fertilização de pastagens. Recentemente, a irrigação surgiu como 
mais uma alternativa para o aumento da produtividade e conseqüente; aumento de lucratividade desses sistemas.

A qualidade da forragem ao longo do ano em áreas irrigadas deve ser diferente quando comparada com pastagens não irrigadas. Nesse período, ocorre queda da qualidade nutricional das pastagens. A suplementação de água (irrigação) pode alterar a composição bromatológica e a qualidade nutritiva dessas plantas em dois momentos: durante períodos de veranicos e, principalmente, durante o inverno.

No Brasil Central, os meses secos do ano coincidem com os meses mais frios. Em áreas irrigadas, apesar do suprimento de água, a planta irá produzir menos devido à menor luminosidade e menor temperatura. Isso poderá provocar, no período de inverno, plantas mais tenras e de melhor qualidade.

O florescimento dessas plantas, por outro lado, pode ser responsivo a um hidroperíodo, podendo ocorrer alterações na fisiologia do florescimento devido à irrigação. Por esse motivo, pastagens irrigadas podem apresentar diferenças na qualidade ao longo do ano, quando comparadas com plantas de sequeiro.

Em áreas intensificadas, o manejo de pastagens baseado na pressão de pastejo pode ser inadequado, pois, pressões de pastejo tidas como altas $(<6 \%)$, podem promover altos resíduos de matéria seca verde pós-pastejo, o que significa baixa eficiência de pastejo. Assim, o resíduo de matéria seca verde pós-pastejo, ou apenas a altura do pasto na saída dos animais, pode ser um instrumento no auxílio do bom manejo da planta forrageira, melhor que a pressão de pastejo (Balsalobre, 1996).

Plantas manejadas com resíduos mais altos podem perder qualidade ao longo do ano, pois existe maior renovação de tecidos nas pastagens mais baixas. Por outro lado, naquelas pastagens existe maior seletividade pelos animais. Isso pode fazer com que a forragem consumida seja de tão boa qualidade como nas pastagens manejadas com menor massa de resíduo.

Pastagens manejadas com resíduos mais baixos podem promover menor desempenho dos animais, devido à dificuldade de apreensão da forragem em níveis próximos ao solo. Esse efeito é maior para plantas temperadas, pois como são mais densas, quando manejadas para o mesmo resíduo (em massa), apresentarão alturas muito 
menores que plantas tropicais. Alturas próximas de $2 \mathrm{~cm}$ são comuns em pastagens temperadas. Essa altura do resíduo impede fisicamente que o animal aprofunde o bocado no dossel da pastagem, isso provoca menores tamanhos de bocado e, consequentemente, menor desempenho dos animais.

O capim Tanzânia, introduzido pela Embrapa no ano de 1990, tem sido muito trabalhado na área de fisiologia e manejo, no entanto, a associação da produção, manejo e qualidade alimentar da forragem precisa ser melhor definida.

A avaliação da cinética ruminal da forragem pela metodologia da degradação in situ (Orskov, 1979) apresenta como principais características a praticidade e o baixo custo. Entretanto, a análise das várias frações da matéria seca depende de métodos não convencionais, pois a quantidade de material residual de cada tempo de incubação é insuficiente para se fazer as determinações laboratoriais de todas as frações que se tem interesse hoje em dia.

$\mathrm{O}$ uso da metodologia do infravermelho proximal (Nirs) viabiliza estudos detalhado das degradações das frações da parede celular (FDN, FDA e lignina), assim como das frações nitrogenadas ( $\mathrm{nFDN}, \mathrm{nFDA}, \mathrm{NnP}$, Nsol), pois, com a análise destrutiva (convencional) de alguns tempos para cada fração pode se estimar com certa segurança os valores dessas determinações para todos os tempos e com isso se fazer o cálculo das degradações e taxas de degradações.

Maximizar o consumo de matéria seca é o objetivo de qualquer sistema de produção. O consumo de matéria seca de animais em pastejo é ponto chave para a definição do balanceamento de dietas visando o maior desempenho animal, uma vez que a definição do consumo por animais em pastejo permite: formular rações, prever o desempenho, estimar a demanda de alimentos ou exigências (Mertens, 1994).

O objetivo do presente trabalho foi de determinar para o capim Tanzânia irrigado manejado sob três resíduos pós-pastejo (Alto, Médio e Baixo): a composição bromatológica ao longo de um ano; a cinética de degradação ruminal das diferentes frações, carboidratos e protéicas, de amostras simulando o pastejo; o consumo de matéria seca de forragem em três períodos do ano (verão, outono e primavera). 


\section{REVISÃO DE LITERATURA}

\subsection{Qualidade bromatológica}

As plantas tropicais, como é o caso do capim Tanzânia, absorvem o $\mathrm{CO}_{2}$ do meio via o ciclo $\mathrm{C} 4$. Essas plantas são caracterizadas por apresentarem altas taxas de crescimento. Assim, com o avanço da idade fisiológica, perdem qualidade mais rapidamente, quando comparadas às plantas que predominam em países de clima temperado que possuem o sistema absorção do $\mathrm{CO}_{2}$ denominado C3 (Van Soest, 1982).

Além de apresentarem qualidade nutricional inferior, caracterizada por maiores proporções de parede celular, também apresentam menores teores de proteína, pois, por serem mais eficientes na retirada de $\mathrm{CO}_{2}$ do meio, possuem menores proporções da enzima Rubisco que as C3, e portanto, menores concentrações de nitrogênio em seus tecidos fotossinteticamente ativos.

\subsection{Carboidrato}

À medida que a idade fisiológica da planta avança, aumentam as porcentagens de hemicelulose, celulose e lignina e a lignificação da parede celular, reduzindo assim a proporção do conteúdo celular, o qual apresenta 98 a $100 \%$ de digestibilidade. O teor de proteína, lipídios e minerais tende a se reduzir, principalmente após o florescimento.

A lignina cria uma barreira física à ação dos organismos fermentadores, sendo que, os maiores teores são observados na época de florescimento. A lignina forma ligações covalentes complexas com carboidratos da parede celular, os quais se associam com frações de hemicelulose. A digestibilidade da parede celular é, no entanto, 
influenciada tanto pelo teor como também pelas características físicas dos polissacarídeos da parede, como o grau de cristalinidade e polimerização (Fritz et al., 1990).

O CNCPS adota uma relação linear entre o teor de lignina e a porção indegradável de carboidratos (fração C). Assim, à medida que a idade fisiológica da planta avança, ocorre aumento da fração C (Caballero et al., 2001). No entanto, Traxler et al. (1998), mostram que o aumento no teor de lignina e a queda da digestibilidade da FDN não seguem uma relação linear, uma vez que a lignina não tem efeito na digestibilidade da parte solúvel da parede celular.

A hemicelulose é a fração mais afetada pela lignificação. Apesar dessa fração apresentar maior potencial de digestibilidade que outros componentes da parede celular, essa não tem sua degradação maximizada, pois apresenta maior proporção não ligada à lignina na parede primária. Como a degradação da célula inicia-se pelo seu interior seguindo para a parede secundária, quando o microorganismo atinge a parede primária, que é a porção externa da célula, a partícula já está deixando o rúmen. Desse modo, plantas forrageiras de maior idade fisiológica apresentam maior redução na digestibilidade da hemicelulose que da celulose (Messman et al., 1991) (Tabela 1).

A Tabela 1 indica que à medida que a idade da planta avança, do início do florescimento para o florescimento pleno, as degradações das frações, tanto potencial como efetiva, se reduzem. Sendo a degradação efetiva a expressão do real aproveitamento do alimento pelo ruminante, sua variação fornece melhor indicação da qualidade do alimento. Desse modo, nota-se que, com o avanço da idade, a redução da degradação efetiva da FDN e da hemicelulose é maior que para FDA e celulose. Para a FDA e para a celulose ocorre significativa queda da degradação potencial, no entanto, a degradação efetiva não se altera, ou é até mesmo maior em plantas mais velhas.

$\mathrm{O}$ aumento no teor de lignina afeta diretamente a fração degradável da FDN (fração B2). À medida que ocorre avanço na idade fisiológica da planta ocorre redução dessa fração (Caballero et al., 2001). 
Tabela 1. Degradação efetiva e potencial da FDN, FDA, hemicelulose e celulose, em amostras de Bromegrass (Bromus inermis L.), em dois estádios de maturidade.

\begin{tabular}{lcc}
\hline Item & Início do florescimento & Pleno florescimento \\
\hline Degradação potencial da FDN & 74,60 & 62,20 \\
Degradação potencial da FDA & 71,70 & 58,40 \\
Degradação potencial da hemicelulose & 78,50 & 66,60 \\
Degradação potencial da celulose & 75,20 & 64,50 \\
Degradação efetiva da FDN & 53,40 & 41,20 \\
Degradação efetiva da FDA & 36,40 & 41,10 \\
Degradação efetiva da hemicelulose & 58,30 & 41,40 \\
Degradação efetiva da celulose & 40,90 & 44,10 \\
\hline
\end{tabular}

Adaptado de Messman et al. (1991).

Por outro lado, as gramíneas tropicais apresentam baixos teores de carboidratos solúveis e amido, frações A e B1, raramente superiores a $20 \%$ dos carboidratos totais (CT) (Vieira, et al., 2000b). Assim, a hemicelulose é a responsável pela maior taxa de fermentação ruminal e portanto, é a maior fornecedora de energia para o crescimento microbiano.

Desse modo, a relação lignina/FDN é um fator importante a ser analisado no que diz respeito à qualidade da planta forrageira. Forragens que apresentam baixos valores de lignina em relação a FDN, disponibilizam altas proporções de hemicelulose para a fermentação ruminal. Assim, poderia se inferir que essas plantas podem apresentar altas proporções de parede celular, porém de boa qualidade.

As plantas do gênero Cynodon são caracterizadas por terem altas proporções de FDN, eventualmente menores que 75\%, no entanto, apresentam teores de lignina relativamente baixos. Isso lhes confere boa qualidade, evidenciada por bons ganhos de peso de animais quando em pastejo dessa forragem (Pedreira et al., 2000). 
Por outro lado, plantas que apresentam baixas proporções de FDN, porém, alta relação lignina/FDN, tem sua parede celular de qualidade inferior. As plantas temperadas apresentam baixos teores de FDN, porém, muitas vezes de qualidade inferior em relação à FDN das plantas tropicais, pois pequenas quantidades de lignina na matéria seca representam altas proporções em relação à FDN dessas plantas.

Em uma planta temperada, Vicia sativa, Caballero et al. (2001) encontraram teores de lignina entre 4,69 e 6,97\% MS para amostras de plantas em três estágios fisiológicos, do início de florescimento para a fase 2 de formação de sementes $(380 \mathrm{~g} / \mathrm{Kg}$ MS de semente), respectivamente. Esses valores de lignina representam entre 13,62 e $16,30 \%$ de lignina em relação a FDN.

Em plantas de Panicum virgatum L. (Switchgrass), Twidwell et al. (1988), obtiveram teores de lignina entre 4,15 e 6,75\% MS para estágios de crescimento semelhantes aos do trabalho de Caballero et al. (2001). Nesse caso, os teores de lignina em relação à FDN foram entre 6,19 e 9,31, respectivamente para o dia de emissão da folha bandeira e o $28^{\circ}$ dia da emissão dessa folha.

Vieira et al. (2000b) em amostras de extrusa de animais sob pastagens naturais, encontraram variação no teor de lignina na FDN de 7,26 a 9,75, enquanto que, para a fração C a variação foi de 22,11 a 35,39\% dos carboidratos. Nesse caso, entre a estação seca e das águas, a lignina não mostrou diferença, no entanto, a fração $\mathrm{C}$ foi mais elevada no período seco do ano.

A degradação da FDN em plantas tropicais, tem alta correlação com a degradação da matéria seca. Como o teor de lignina aumenta em proporção maior que o teor de FDN com o avanço da idade da planta, a degradação da matéria seca tem correlação maior com a digestibilidade da FDN que com o teor dessa fração. Deschamps (1999), mostra uma correlação de 0,95 entre a degradação da matéria seca e a degradação da FDN em plantas de Brachiaria brizantha, enquanto que a correlação foi de - 0,88 entre a degradação da matéria seca e o teor de FDN (Tabela 2).

A maturidade da planta pode ser alterada ao longo do ano, mesmo em sistemas onde se adota pastejo rotacionado, porém, com períodos de descansos fixos. $\mathrm{O}$ capim Tanzânia pastejado a cada 28, 38 ou 48 dias, apresentou diferentes 
digestibilidades da matéria seca in vitro (DIVMS) para amostras coletadas ao longo do ano $\left(\right.$ Santos $\left.^{1}\right)$ (Figura 1).

Tabela 2. Correlações entre as degradações da FDN e da matéria seca e os teores de FDN e lignina com o avanço da idade de Brachiaria brizantha.

\begin{tabular}{lcccc}
\hline & Idade & FDN (\%) & Deg. FDN (\%) & Deg. MS (\%) \\
\hline FDN (\%) & 0,72 & - & - & - \\
Deg. FDN (\%) & $-0,83$ & $-0,71$ & - & - \\
Deg. MS (\%) & $-0,88$ & $-0,88$ & 0,95 & - \\
Lignina (\%) & 0,84 & 0,61 & $-0,59$ & $-0,72$ \\
\hline
\end{tabular}

Adaptado de Deschamps (1999).

As menores digestibilidades do capim Tanzânia foram verificadas entre os meses de março e julho, independentemente da freqüência de pastejo (28, 38 ou 48 dias). Mesmo para a menor frequiência de pastejo, 28 dias, que teve tendência de apresentar maiores digestibilidades, no período de inverno houve queda de qualidade nutricional $\left(\right.$ Santos $\left.^{1}\right)$.

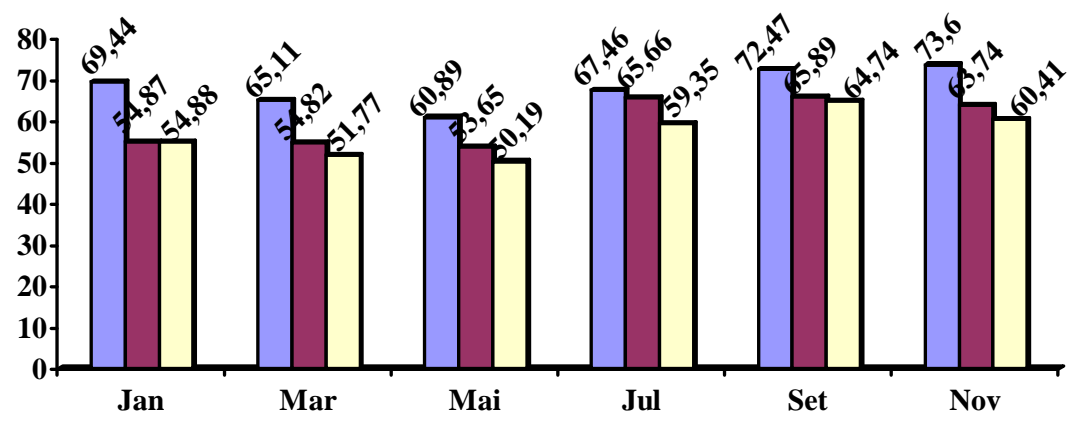

Figura 1- Digestibilidade dos capim Tanzânia de amostras coletadas ao longo do ano em três freqüências de pastejos (28, 38 e 48 dias). (Santos ${ }^{1}$ ).

\footnotetext{
${ }^{1}$ SANTOS, P.M. (ESALQ, Depto Produção Animal, Piracicaba). Comunicação pessoal, 2001.
} 
Essa variação da qualidade nutricional ao longo do ano, em grande parte, é devida ao efeito do florescimento. O florescimento é acompanhado pelo alongamento das hastes. Nesse período, a relação haste:folha aumenta rapidamente, pois além do crescimento das hastes ser maior, o aparecimento de folhas cessa após o lançamento das inflorescências. Em Panicum maximum cvs. Tanzânia e Mombaça, por exemplo, foi observado que as hastes chegavam a representar $70 \%$ da matéria seca disponível entre abril e maio (época do florescimento) (Santos, 1997). Para o capim elefante (Pennisetum purpureum Schum.), Balsalobre (1996) observou que em abril (início do florescimento) as hastes correspondiam a $66 \%$ da matéria seca disponível.

Twidwell et al. (1988), trabalhando com três cultivares de Switchgrass (Panicum virgatum L.) em três estágios de florescimento, reportaram que a qualidade da haste se reduz significativamente após o florescimento (Tabela 3). Esse efeito pode ser constatado pelos maiores teores de FDN e lignina e também pela redução na degradação da MS, redução na taxa de digestibilidade da FDN e na menor extensão de degradação da FDN das hastes em estágios fisiológicos mais avançados. Entretanto, para lâminas foliares, apesar de não ter havido aumento no teor de FDN e lignina com o aumento da proporção de inflorescência, a digestibilidade da MS e a extensão de degradação da FDN foram menores com o avanço da idade.

Parsons et al. (1988) ressaltam a importância de se controlar a produção de hastes no pasto. A presença de hastes pode reduzir a eficiência do sistema de duas formas: limitando a capacidade de colheita da forragem pelo animal ou reduzindo o seu valor alimentar.

Dentre os fatores do ambiente que interferem no florescimento, os mais estudados são o fotoperíodo e a temperatura, sendo que diversas interações entre os mesmos são descritas na literatura. Outro fator climático que pode interferir no florescimento é o estresse hídrico. Esse é menos estudado em plantas forrageiras, no entanto, de fundamental importância em áreas irrigadas. 
Tabela 3. Digestibilidade in vitro da matéria seca (DIVMS), taxa de digestibilidade in vitro da MS (c MS, \%/h), extensão de degradação da FDN em 96 horas (Ex. FDN), teor de FDN e teor de lignina de haste e lâmina de folhas de Switchgrass (Panicum virgatum L.) em três estágios de florescimento.

\begin{tabular}{llcccc}
\hline Variável & Componente & \multicolumn{3}{c}{$\%$ de inflorescência na MS } & Regressão \\
& & 2,2 & 8,9 & 17,1 & \\
\hline DIVMS (\%) & Lâmina foliar & 66,50 & 66,30 & 61,20 & $* * *$ \\
& Haste & 54,90 & 40,30 & 33,90 & $* * *$ \\
c MS (\%/h) & Lâmina foliar & 5,70 & 5,30 & 5,00 & NS \\
& Haste & 6,50 & 5,10 & 4,10 & $* * *$ \\
Ex. FDN (\% FDN) & Lâmina foliar & 77,50 & 73,50 & 72,00 & $* * *$ \\
& Haste & 56,60 & 39,40 & 33,80 & $* * *$ \\
FDN (\% MS) & Lâmina foliar & 61,90 & 61,80 & 62,50 & NS \\
& Haste & 78,20 & 80,70 & 81,70 & $* * *$ \\
Lignina (\% MS) & Lâmina foliar & 2,99 & 3,30 & 3,61 & NS \\
& Haste & 6,94 & 9,87 & 10,82 & $* * *$ \\
\hline
\end{tabular}

*** as regressões são significativas para $\mathrm{P}<0,05$.

Adaptado de Twidwell et al. (1988).

As plantas que florescem quando o fotoperíodo é menor que o valor crítico, são consideradas de "dia curto", e aquelas que florescem em resposta à comprimentos do dia acima do valor crítico, são classificadas de "dia longo". As plantas indiferentes florescem independentemente do fotoperíodo, enquanto as intermediárias só vão florescer quando submetidas a comprimentos de dia intermediários, ou seja, dias muito longos ou muito curtos inibem o processo (Taiz e Zeiger, 1991; Hopkins, 1995).

As plantas de dias curtos ou de dias longos podem ainda ser classificadas como qualitativas ou quantitativas. Nas plantas qualitativas, o florescimento só ocorre se as exigências quanto ao fotoperíodo forem atendidas, no entanto, as quantitativas 
aceleram o processo de florescimento a partir de determinado comprimento do dia (Taiz e Zeiger, 1991; Hopkins, 1995).

As forrageiras da espécie Panicum maximum, em geral, são classificadas como plantas de dia curto. No caso do Capim Colonião, o fotoperíodo crítico é de 12 a 14 horas (Felippe, 1978). O cultivar Gatton panic é uma planta de dia curto quantitativa respondendo a fotoperíodos entre 12 e 14 horas (Hopkinson e English, 1982).

\subsection{Proteína}

A qualidade da planta forrageira deve ser analisada não só em relação às alterações na parede celular, mas também em relação à porção protéica, tanto em teores como em sua composição.

A determinação da porção da proteína dos alimentos que se degrada no rúmen ou pós-rúmen trouxe grandes avanços no entendimento da nutrição animal (Nutricional Research Council -NRC, 1990). A introdução do CNCPS, sendo um modelo dinâmico, possibilitou a melhor compreensão das interações das frações dos alimentos (Sniffen et al., 1992; Russel et al., 1992; Fox et al., 1992).

Sniffen et al. (1992), dividem a proteína das plantas em cinco frações. A parte solúvel da proteína é dividida em fração A e B1. A fração A, é o nitrogênio não protéico $(\mathrm{NnP})$, de alta digestibilidade no rúmen. O restante da fração solúvel (B1) é uma parte da proteína verdadeira, que também tem rápida degradação ruminal. A fração $\mathrm{C}$ é a proteína indisponível, é a parte da proteína contida na FDA (nFDA). Está associada com lignina, formando complexos de tanino e produtos da reação de Maillard que são altamente resistentes a degradação microbiana e enzimática.

Existe uma fração do nitrogênio contido na FDN, designada de nFDN. A subtração do nFDA do nFDN é uma outra forma da proteína na planta. Essa estaria disponível, porém com uma taxa de degradação muito lenta, é a fração B3 (Sniffen et al., 1992). A última fração, a B2, apresenta taxa de degradação média, é a fração da proteína que não é solúvel, não faz parte da parede celular e também não é NnP. 
O capim elefante, pastejado a cada 45 dias de intervalo, apresentou 8,90\% de proteína na matéria orgânica (MO) para amostras simulando o pastejo. Nessas amostras, as frações de $\mathrm{NnP}$, Nsol, nFDN, nFDA foram respectivamente: 26,02; 39,11; 47,35 e 9,13\% da proteína total (Balsalobre, 1996). Também para amostras de capim elefante, Lagunes $^{2}$, da Universidade de Cornell, obteve, para crescimento de 42 dias, 13,48; 20,22; 23,59 e 3,37\%, respectivamente para as frações NnP, Nsol, nFDN e nFDA. Os valores obtidos por Balsalobre (1996) são elevados em relação aos de Lagunes², principalmente a fração indisponível (nFDA).

Os teores de nitrogênio ligados aos compostos da parede celular tendem a aumentar com a idade fisiológica da planta, principalmente, aquela fração ligada a FDA. Lima et al. (1999) encontraram uma redução linear na fração da proteína de lenta degradação (fração B3) com a maturidade de plantas de Tifton-85 (Cynodon dactylon), Bahia (Paspalum notatum) e Floralta (Hemarthria altissima). Com quatro semanas de idade essas plantas apresentavam $76,40 \%$ do $\mathrm{N}$ na forma de proteína de lenta degradação, enquanto que, com oito semanas, o valor dessa fração foi de 70,40\% do $\mathrm{N}$ total. No entanto, não houve para essas plantas aumento significativo de nFDN e nFDA com o avanço da idade. Os valores de nFND foram entre 37,40 e $41,70 \%$ do $\mathrm{N}$ total, enquanto que para o nFDA esses valores foram entre 4,68 e 7,27\% do $\mathrm{N}$ total.

Em plantas de Tifton-85 o NnP variou entre 15,90 e 21,80\%, para Hemarthria o NnP foi entre 11,40 e 20,10, enquanto que para Bahia essa fração nitrogenada esteve em patamares menores, entre 7,50 e 8,50\% (Lima et al., 1999).

Lima et al. (1999), concluíram que para plantas de Hermathria, Tifton-85 e Bahia, os teores de proteína de rápida degradação ruminal (soma das frações A e B1), foram muito baixos, respectivamente, 15 a 30,22 a 38 e 12 a $22 \%$ do $\mathrm{N}$ total. Em plantas de Vicia sativa, Caballero et al. (2001) encontraram redução da fração B1 de 30,81 para 23,87\% com o avanço da idade, do início da emissão da folha bandeira para o $14^{\circ}$ dia da emissão dessa folha, respectivamente.

\footnotetext{
${ }^{2}$ LAGUNES, F.J. (Cornell University). Comunicação pessoal, 1996.
} 
Barros et al. (2000), mostraram uma correlação linear entre a concentração de $\mathrm{N}$ na planta e a adubação nitrogenada quando plantas de Tanzânia foram adubadas entre 60 e $180 \mathrm{~kg} \mathrm{~N} / \mathrm{ha}\left(\mathrm{PB}(\% \mathrm{MS})=9,2789+0,012 \mathrm{~N}(\mathrm{~kg} / \mathrm{ha}) ; \mathrm{R}^{2}=0,8568\right)$.

$\mathrm{O}$ teor de $\mathrm{N}$ total aumentou de 0,99 para 1,47\% MS, quando uma área com mistura de forrageiras tropicais foi adubada com 0 e $80 \mathrm{~kg} / \mathrm{ha}$ de $\mathrm{N}$ (Clliers et al., 1997). Nesse caso, o teor de NnP também aumentou de 0,12 para 0,21\% MS, respectivamente, para fertilização de 0 e $80 \mathrm{~kg} / \mathrm{ha}$ de $\mathrm{N}$. No entanto, os aumentos do teor de $\mathrm{NnP}$ em relação ao $\mathrm{N}$ total foram menores, de 12,10 para 14,27\% PB. Desse modo, pode se dizer que houve aumento da síntese líquida de proteína a medida que se aumentou a adubação nitrogenada (Clliers et al., 1997).

No trabalho de Glenn et al. (1985), houve aumento no teor de proteína em uma planta temperada, a festuca (Festuca arundinaceae Schreb.), conforme a adubação nitrogenada aumentou de 0 para $300 \mathrm{~kg} / \mathrm{ha} . \mathrm{ano}^{-1}$. O aumento foi de $14,7 \%$ para 21,5\% de proteína total na MS, o que corresponde a um incremento de $47 \%$. O N protéico, porém, apresentou aumentos de 58\%, enquanto que, o $\mathrm{NnP}$ se elevou em $24 \%$.

As plantas apresentam uma concentração ótima de $\mathrm{N}$ para a fotossíntese. Nas plantas C4 essa concentração é maior que para as plantas C3. O teor de NnP pode estar associado à adubação nitrogenada, estando a planta com nível ótimo da [N], o aumento no fornecimento de $\mathrm{N}$ irá determinar um consumo de luxo e, consequentemente, aumento do $\mathrm{NnP}$.

Malafaia et al. (1997), encontraram para 4 plantas tropicais (Tifton-85, Capim elefante, Brachiaria brizantha e Brachiaria decumbens) valores para a fração C variando entre 11,66 e 27,73\% PB. A fração A variou de 11,58 a 32,28\% PB, enquanto que as frações B1, B2 e B3 tiveram variações entre 0,58 e 4,54; 32,97 e 43,62; 17,55 e $34,17 \%$ PB, respectivamente. Nesse trabalho, a Brachiaria brizantha apresentou a pior qualidade da proteína, a soma das frações B3 e C foi de 51,90\% da PB, enquanto que, a Brachiaria decumbens apresentou a menor proporção da proteína na forma das frações C e B3, a soma, nesse caso, foi de $29,21 \%$ da PB. A Brachiaria decumbens também apresentou o maior valor para a fração A, 32,28\% e a Brachiaria brizantha o menor, $11,58 \%$ da PB. 
O fracionamento da proteína pode ter influência da espécie forrageira, no entanto, parece ser mais dependente do manejo, idade fisiológica e adubação nitrogenada.

Vieira et al. (2000a), em pastagens nativas encontraram valores entre 5,20 e $13,19 \%$ da proteína para a fração $\mathrm{A}$, sendo os maiores valores encontrados no período das secas. A fração indisponível, fração C, apresentou valores entre 19,83 e 35,11, também sendo os maiores valores para a estação seca. As frações B1, B2 e B3 estiveram entre 3,94 e 14,53; 15,99 e 23,45; 21,31 e 55,04\% PB, respectivamente, para o período de águas e seca.

\subsection{Qualidade e estresse hídrico}

Como já discutido anteriormente, ao longo do ano a qualidade da planta se altera, mesmo tendo o pastejo rotacionado como base de manejo da pastagem. O melhor exemplo desse conceito em pastagens de capim Tanzânia é o trabalho de Santos (1997), onde pode se observar a queda de qualidade da planta a partir do mês de maio, para períodos de descanso de 28, 38 e 48 dias.

O motivo da queda de qualidade da planta após o outono é provavelmente o seu florescimento. No Brasil Central o período de inverno é caracterizado não só pelas menores temperaturas como também pela falta de precipitação pluviométrica. Como relatado na literatura (Vough et al., 1971; Halim et al., 1989), estresse hídrico promove melhoria na qualidade da forragem, aumentando a digestibilidade da MS e reduzindo a relação haste/folha. No entanto, em condições de Brasil Central, o efeito do florescimento parece ser maior que o efeito do estresse hídrico, pois a qualidade da planta é reduzida sensivelmente no período de inverno (Santos, 1997).

Por outro lado, Paciullo et al. (1999) encontraram que a espessura da parede das células do esclerênquima de plantas de braquiárias aumentou de espessura de forma linear com a redução do conteúdo de água no solo $($ Espessura $(\mu \mathrm{m})=2,356-0,0327 *$ $\%$ de água no solo). Isso pode indicar uma redução de qualidade da planta, associada a estresse hídrico prolongado. Wilson et al. (1995), indicam uma redução do ataque de 
microorganismos quando da maior espessura das células da parede celular, reduzindo assim a digestibilidade da planta.

Áreas irrigadas podem apresentar plantas com melhor qualidade durante o inverno que áreas não irrigadas, isso por dois motivos: a não incidência de estresse hídrico e a alteração no florescimento da planta.

\subsection{Degradações de frações carboidrato e protéica}

Com a divulgação dos conceitos usados no CNCPS através dos trabalhos de Sniffen et al. (1992), Fox et al. (1992) e Russel et al. (1992), desenvolveram-se trabalhos no sentido de se explorar a cinética ruminal tanto das frações nitrogenadas como de carboidratos. O objetivo desses trabalhos é o de fornecer informações na tentativa de encontrar a adequada sincronização entre a degradação ruminal da proteína e dos carboidratos.

Assim, nos últimos anos trabalhos foram realizados seguindo as metodologias do CNCPS. No Brasil algumas universidades e centros de pesquisa têm procurado detalhar melhor as degradações das diferentes frações da planta.

Malafaia et al. (1997) caracterizaram as frações nitrogenadas e avaliaram a cinética ruminal dessas frações em algumas gramíneas tropicais. Em plantas de Tifton85, Capim-elefante, Brachiaria brizantha e Brachiaria decumbens, encontraram para a fração B1 taxas de degradações de 191,28; 69,73; 132,19 e 78,29 \%/h, respectivamente. Para essas mesmas plantas as frações B2 e B3 foram de 1,29 e 0,15; 1,67 e 0,06; 1,13 e 0,25; 1,16 e 0,95 \%/h, respectivamente para Tifton-85, Capim-elefante, Brachiaria brizantha e Brachiaria decumbens. Essas taxas de degradações das frações protéicas foram determinadas através da utilização de proteases extraídas do líquido ruminal. Para Plantas de Tifton-85 e Capim-elefante, o NRC (1996) indica valores de 135, 11 e 0,09 \%/h como taxa de degradações para as frações B1, B2 e B3 respectivamente. Assim, pode se dizer que as taxas encontradas para B1 e B3 estão próximas dos valores citados pelo NRC (1996). No entanto, para as taxas de degradação das frações B2, os valores encontrados nesse trabalho estão muito abaixo do recomendado pelo NRC (1996). 
Vieira et al. (2000a) trabalharam com o fracionamento de amostras da extrusa de animais em pastagens naturais da Zona da Mata, MG. Essas amostras foram coletadas quatro vezes em duas épocas do ano, chuvas e seca. As determinações das taxas de degradações e da degradação potencial das frações protéicas B1, B2 e B3 foram obtidas in vitro com proteases originadas do Streptomyces griseus. As taxas de degradação das frações B2 e B3 variaram entre 164 a 322 e 3,2 a 8,0 \%/h, respectivamente. Os maiores valores encontrados foram para início da estação das chuvas, assim como, as degradações potenciais para as frações B2 e B3 que foram maiores também para o início da estação das chuvas. Para a fração B2 a degradação potencial foi próxima de $100 \%$, enquanto que para a fração B3 foi entre 59,50 e 79,60 \%.

As taxas de degradações encontradas por Vieira et al. (2000a) para as frações B2 e B3 da proteína, apontam para valores bem maiores que os indicados por Malafaia et al. (1997). Vieira et al. (2000a) justificam essas diferenças de duas formas: devido ao tratamento matemático aplicado aos diferentes intervalos de linearidade para degradação de cada fração (Vieira et al., 1997), e também por serem suas análises originadas de amostras de extrusa, o que pressupõe que seriam de melhor qualidade quando comparadas com amostras simulando o pastejo.

Ribeiro et al. (2001) avaliaram a taxa de degradação das diferentes frações da proteína e dos carboidratos de amostras de feno de Tifton- 85 colhido em diferentes idades de rebrota $(28,35,42$ e 56 dias). As frações protéicas, B2 e B3, apresentaram taxas de degradações que variaram de 7,24 a 9,36 e entre 0,77 e $1,20 \% / \mathrm{h}$, respectivamente, sendo que houve tendência de redução das taxas de degradação com o avanço da idade da planta. No caso da fração B2 dos carboidratos a variação da taxa de degradação foi de 4,00 a $4,66 \% / \mathrm{h}$, sendo os menores valores para plantas de maior idade fisiológica.

Vieira et al. (2000b) avaliaram as taxas de degradações das frações carboidratos de amostras de extrusa em pastagens nativas coletadas em duas épocas do ano, águas e seca. A fração B2 dessas amostras apresentou taxas de degradação de 9,00 $\% / \mathrm{h}$ no período das águas e de $6,20 \% / \mathrm{h}$ no período de seca. Enquanto, a degradação efetiva (DE) dessas amostras foi de 73,50 e 68,50 para águas e seca, respectivamente. 


\subsection{Resíduo pós-pastejo}

Muitos trabalhos relatam a relação do resíduo com o desempenho animal. Quanto maior o resíduo pós-pastejo maior o desempenho, seja esse resíduo medido em altura (Hodgson et al., 1994), ou em massa de forragem (Holmes et al., 1984; Almeida, 2000). No entanto, essa relação não é linear, pois segue uma assintótica, e após certo ponto os desempenhos individuais não aumentam. Isso significa que resíduos maiores promovem menores lotações com mesmo desempenho por animal, ou seja, menor ganho por área.

A quantidade de resíduo pós-pastejo interfere significativamente sobre o consumo animal conforme trabalhos realizados com gramíneas temperadas. Holmes et al. (1984) citaram consumos crescentes à medida que o resíduo passou de 800 para 1800 $\mathrm{kg}$ de MS/ha. Nesse caso, vacas em lactação aumentaram o consumo de 2,50 para 4,80\% do peso animal.

Essa relação assintótica entre consumo de forragem e resíduo pós-pastejo, permite inferir sobre a possibilidade de se planejar sistemas de pastejo mais eficientes, tanto na utilização da forragem disponível, como no desempenho animal, refletindo significativamente em aumento da produtividade animal.

A pressão de pastejo aceita como ideal para bons desempenhos animais é da ordem de $6-8 \%$. Sistemas de produção que exploram elevadas disponibilidade de forragem, quando baseados apenas na pressão de pastejo, provocam níveis maiores de resíduos pós-pastejo, o que poderá causar redução no aproveitamento da forragem (Balsalobre, 1996).

Poucos trabalhos em pastagens tropicais referem-se à pressão de pastejo e resíduos pós-pastejo. Hillensheim (1987) obteve o mesmo consumo de matéria seca (1,4\% do peso animal de novilhas holandesas) utilizando Capim-elefante sob pressões de pastejo de 4; 8 e 12\%, onde os resíduos pós-pastejo foram de 2680 a $4902 \mathrm{~kg}$ MS/ha, respectivamente para 4 e $12 \%$ de pressão de pastejo. 
Almeida (2000), trabalhando com Capim-elefante anão indicou que a disponibilidade de forragem deve estar compreendida entre 10,5 e 14,7 kg de MS de lâminas de folhas verdes para cada $100 \mathrm{~kg}$ de peso animal/dia para garantir perenidade da planta forrageira. Esses valores correspondiam aproximadamente a 2000 e $2500 \mathrm{~kg}$ de lâmina verde de resíduo pós-pastejo.

Segundo Stobbs (1973) o animal apresenta um tempo de pastejo limitado durante o dia, que dificilmente ultrapassa 9 horas, também dificilmente consegue dar mais de 4000 bocados por hora. Portanto, o tamanho de cada bocado é o que pode definir o consumo de forragem por um animal.

A quantidade de forragem apreendida em cada bocado é função do volume do bocado e da densidade da forragem que está sendo pastejada. $\mathrm{O}$ volume do bocado por sua vez é função da profundidade do bocado no dossel, multiplicado pela área que esse bocado consegue atingir (Burlison et al., 1991).

Estudos tem mostrado que a profundidade do bocado é mais importante que a área e que, em muitos casos, é o maior determinante no volume e consumo de cada bocado (Burlison et al., 1991).

A altura da planta está relacionada diretamente com o aumento do tamanho do bocado, tendo um comportamento linear com o aumento da altura da planta (Burlison et al., 1991). Hodgson et al. (1994), apresentaram o conceito de proporcionalidade constante de remoção de forragem, onde cada bocado tem uma altura constante e proporcional à altura da pastagem.

Por outro lado, Laca et al. (1993) encontraram uma curva assintótica, ou seja, quanto mais alta a planta mais profundo foi o bocado, porém com acréscimos decrescentes. No caso do azevém perene e festuca, a penetração da boca do animal no dossel da forragem é limitada pelo local de interface da lâmina foliar com o pseudocaule (Laca et al., 1993). A mesma limitação parece ocorrer para as gramíneas tropicais.

A área que o animal consegue abranger pelo bocado varia conforme a altura da planta forrageira, observando-se maior área do bocado para as plantas mais altas. Por outro lado, a densidade $\left(\mathrm{kg} \mathrm{MS} / \mathrm{cm}^{3}\right)$ da forragem esteve diretamente relacionada à área 
do bocado, sendo esse efeito mais pronunciado em forragens esparsas que em forragens densas (Mitchell et al., 1993).

Em forragens tropicais, o consumo por bocado foi mais sensível às variações na densidade da forragem do que a altura das plantas (Stobbs, 1973), refletindo características próprias das forrageiras tropicais.

Costa et al. (2001) não encontraram diferenças na taxa de bocados quando pastagens de Tanzânia foram pastejadas em três alturas: 52,85, 68,36, 74,71 cm (média de três dias de pastejo). No entanto, para o tratamento de menor altura de pastejo o tempo de pastejo foi maior, provavelmente uma forma dos animais compensarem o menor tamanho de bocado em pastagens mais baixas.

Carvalho et al. (2001), mostram que plantas altas podem reduzir o consumo de forragem em ovelhas devido a redução na velocidade de ingestão de cada bocado. Pastagens de Tanzânia manejadas em três resíduos: baixo $(15 \mathrm{~cm})$, médio $(24 \mathrm{~cm})$ e alto (60 cm), que representaram, respectivamente, massa de forragem de 2673, 2981 e 4255 $\mathrm{kg} \mathrm{MS} / \mathrm{ha}$, mostraram um aumento no tempo de cada bocado de $1,85 \mathrm{~s}$, para o resíduo baixo para 2,55 s, para o mais alto. Carvalho et al. (2001) ressaltam que mesmo o tamanho do bocado sendo maior para as maiores alturas de resíduo, a menor taxa de ingestão pode levar a menores consumos em maiores disponibilidades de forragem.

A influência da altura da pastagem, analisada nos três dias de pastejo de uma mesma área, mostra maior tempo de pastejo para o primeiro dia de ocupação $(10,08$ horas para 83,50 cm de altura), comparado ao terceiro dia de pastejo (8,57 horas para uma altura de 46,05 cm). Além disso, observa-se uma menor taxa de bocados para o terceiro dia de pastejo (1263 bocados/hora), comparado ao primeiro dia (1546 bocados/hora) (Costa et al., 2001).

Pastagens manejadas em menores alturas podem apresentar melhor qualidade nutricional, explicada pela maior renovação da população de perfilhos. O capim Tanzânia manejado em intensidades de pastejo (alta, média e baixa) apresentava cerca de 11,30 e $37 \%$ de perfilhos com mais de 99 dias de idade, respectivamente, para as intensidades alta, média e baixa. Nesses mesmos tratamentos, a intensidade de pastejo 
alta apresentava 59\% dos perfilhos com menos de 66 dias, a intermediária $50 \%$ e o tratamento de baixa intensidade de pastejo apenas 39\% (Santos et al. 2001).

Plantas de Tanzânia manejadas em resíduos mais baixos também podem apresentar melhor qualidade, devido à maior proporção de folhas. Intensidades de pastejo maiores promoveram maior proporção de folhas e maiores proporções de folhas novas que os tratamentos com intensidades intermediária e alta (Aguiar et al., 2001).

Plantas de Tanzânia manejadas em alturas de 25, 44, 52 e $75 \mathrm{~cm}$, apresentaram, nas menores alturas de pastejo, maiores teores de proteína, menores teores de FDN e FDA e maiores digestibilidade da matéria seca. Entretanto, ao longo das coletas, entre janeiro e maio, houve redução da digestibilidade da forragem e essa foi melhor explicada pela ordem da coleta do que pela altura da planta (Rego et al., 2001).

Clliers et al. (1997), verificaram melhor qualidade da forragem em menores alturas de resíduo, promovida pela maior lotação animal (0,52, 0,78 e 1,56 UA/ha). Essa maior lotação provocou menor ganho de peso individual $(0,99,0,68$ e 0,25 $\mathrm{kg} /$ cabeça/dia), no entanto, a lotação intermediária promoveu os maiores ganhos de carcaça por unidade de área $(70,90,81,40$ e $59,40 \mathrm{~kg} / \mathrm{ha})$.

\subsection{Efeito da qualidade da planta e a nutrição animal}

O potencial de utilização de uma forragem depende da interação entre planta, microorganismo e trato gastrointestinal do animal. O processo de digestão compreende a taxa de digestão (kg MS/hora), o "lag time" (horas), a fração potencialmente digestível (fração rapidamente digestível, lentamente digestível) e a indigestível. O tamanho da fração potencialmente digestível é mais importante que taxa de digestão e "lag time" (Mertens \& Ely, 1982).

A taxa de passagem pelo rúmen e o tempo de retenção estão relacionados com o nível de consumo, forma física da dieta e tempo de ruminação, enquanto que, a taxa de digestão da fibra pode ser reduzida pelo $\mathrm{pH}$ ruminal, pois esse provoca alterações na taxa de crescimento dos microorganismos e na atividade enzimática. 
A digestibilidade da fibra é um importante fator influenciando o consumo de MS. A fibra indigestível pode ocupar o trato digestivo tomando a capacidade do rúmen e, consequentemente, reduzindo o espaço ruminal e o consumo de MS (Thiago \& Gill, 1990).

O consumo de MS é determinado pela taxa de digestão e taxa de passagem do alimento pelo rúmen. Forragens tropicais apresentam baixos teores de amido e açúcares, que são rapidamente degradáveis no rúmen. A pectina, também de alta degradação ruminal (> 85\%) (Merchen et al., 1994), apresenta baixas proporções em forragens tropicais. As outras frações da parede celular, hemicelulose e celulose, têm suas degradações sujeitas aos efeitos da lignificação conforme a idade fisiológica da planta.

A sincronização entre proteína e energia degradável no rúmen é o objetivo dos balanceamentos de dietas. Como pode ser verificado na Tabela 4, a maior proporção da parede celular é degradada no rúmen, assim, em dietas exclusivas de forragens, não mais que 5 à $8 \%$ dos carboidratos rapidamente fermentecíveis escapam da degradação ruminal.

Tabela 4. Composição, consumo voluntário de carneiros, e digestibilidade da parede celular de Phalaris tuberosa, cortada em três estágios de maturidade.

\begin{tabular}{lccc}
\hline Item & Estágio 1 & Estágio 2 & Estágio 3 \\
\hline Concentração & \multicolumn{3}{c}{$\mathrm{g} / \mathrm{kg}$ de matéria orgânica } \\
FDN & 43,60 & 62,80 & 74,90 \\
Lignina & 3,00 & 4,10 & 7,40 \\
Carboidratos solúveis & 20,90 & 15,10 & 11,30 \\
Consumo g MO/kg PV ${ }^{0,75} \cdot$ dia $^{-1}$ & 61,40 & 53,70 & 46,30 \\
Digestão da FDN & & & \\
Trato total (\% do consumido) & 82,20 & 75,80 & 51,50 \\
Ruminal (\% do digerido) & 95,30 & 85,80 & 75,30 \\
\hline
\end{tabular}

Adaptado de Merchen et al. (1994). 
O NRC (1996), recomenda que a quantidade de proteína degradável no rúmen (PDR) deva ser por volta de $13 \%$ do total de matéria orgânica degradável (MOD). Esse valor é similar ao proposto pelo Agricultural and Food Research Council - AFRC (1992), enquanto que, o Agricultural Research Council - ARC (1980) propõe que deve haver uma valor médio de $30 \mathrm{~g}$ de $\mathrm{N}$ microbiano/kg de matéria orgânica aparentemente digerível (MOAD). Considerando, em média $65 \%$ da MOD sendo aparente, e transformado o $\mathrm{N}$ microbiano em proteína microbiana, tem se $12,2 \mathrm{~g}$ de $\mathrm{PB}$ microbiana/100 g de MOD. Portanto, os três sistemas, NRC, AFRC e ARC, apontam para valores semelhantes entre PDR e MOD.

Em forragens de baixa qualidade, apesar da baixa disponibilidade de energia, a falta de proteína degradável no rúmen é fator limitante para se atingir maiores consumos de MS, maior digestibilidade da forragem e conseqüente maior desempenho animal (Heldt et al., 1999).

A maximização da fermentação ruminal é o caminho para se ter maior produção microbiana, pois a síntese de proteína microbiana, que é a principal fonte protéica dos ruminantes, é o produto da eficiência do crescimento microbiana (g de $\mathrm{PM} / \mathrm{kg}$ de MOD) pela MOD. Desse modo, se aumentando o consumo de MS através do aumento da taxa de passagem, haverá maior quantidade de substrato para fermentação ruminal e dessa forma, maior produção microbiana (Clark et al., 1992).

Porém, não só fontes de carboidratos de fermentação ruminal são importantes para a produção microbiana. Há necessidade também de fontes protéicas, pois a $\mathrm{NH}_{3}$ é requerida principalmente por bactérias que degradam carboidratos estruturais (CE), enquanto que, bactérias que fermentam carboidratos não estruturais (CNE), necessitam de aminoácidos e peptídeos (Russel et al., 1992).

Da mesma forma que deficiência de proteína degradável no rúmen é prejudicial ao animal, pois reduz consumo e digestibilidade, altos níveis de proteína na forragem também podem reduzir desempenhos. $\mathrm{O}$ valor de $210 \mathrm{~g}$ de proteína bruta por kg de MOD, foi colocado por Poppi \& McLennan (1995) como sendo o nível máximo para que não se tenha perdas de amônia no rúmen. 
Para forragens temperadas que apresentam $80 \%$ de MOD o nível máximo de PB seria de 15,1\% MS. Dificilmente excesso de PB ocorre em forragens tropicais, pois essas apresentam, nos períodos de melhor qualidade, entre 60 e 70\% de MOD. Desse modo, valores até $13,20 \%$ de PB na MS não apresentariam problemas de perda ruminal de amônia.

O excesso de proteína é transformado em amônia no rúmen, absorvido pela parede ruminal e transformado em uréia para ser excretado via urina. Nesse processo ocorre gasto de energia, esse gasto energético é chamado de custo uréia (Owens et al., 1988). O NRC (1996), calcula o custo uréia através da seguinte fórmula: custo uréia $(\mathrm{Mcal} / \mathrm{d})=[0,012 * \mathrm{~N}(\mathrm{~g} / \mathrm{d}) / 0,45]$, desse modo pode se prever que para cada $100 \mathrm{~g}$ em excesso o custo é de 2,66 Mcal/dia. Essa perda energética pode, portanto, reduzir o desempenho animal, ao contrário do esperado efeito benéfico de se ter uma forragem de alto teor de proteína.

Em pastagens tropicais as frações protéicas de rápida degradação, A e B1, representam grande proporção da proteína. A não ser em algumas exceções (Lima et al., 1999), a soma dessas frações é superior a $20 \%$ do total da proteína. Somando-se a esse total a fração protéica de degradação média, a B2, encontra-se teores acima de $50 \%$ da PB (Malafaia et al., 1997; Vieira et al., 2000a; Lanna et al., 1996). A rápida taxa de degradação dessas frações no rúmen pode promover o aumento da concentração de amônia no meio, fazendo com que haja aumento de perda de nitrogênio.

$\mathrm{O}$ aumento de perda de nitrogênio, em pastagens tropicais, logo após os picos de consumo, pode ser justificado também devido à falta de carboidratos de rápida degradação ruminal, frações A e B1 dos carboidratos (Vieira, et al., 2000b).

Nesses casos, a adição de carboidratos de rápida degradação ruminal, como é o caso do melaço, pode reduzir as perdas de nitrogênio e promover aumento de desempenho animal, proporcionado pela maior síntese de proteína microbiana (Poppi \& McLennan, 1995).

Por outra lado, a fração protéica de lenta degradação, a B3, representa a maior proporção da proteína a atingir o intestino delgado. No entanto, juntamente com a fração C, representa a maior parte das proteínas ingeridas que são excretadas nas fezes. Assim, 
o fornecimento de uma proteína de degradação intermediária, supriria uma eventual deficiência momentânea de proteína ruminal, fazendo com que se tenha maior sincronização da proteína com a MOD disponível no rúmen, o que pode promover maior síntese microbiana.

O fornecimento de concentrados energéticos para animais sob pastejo, provoca os efeitos de substituição de forragem e o de adição em relação ao consumo total da dieta. Esses dois efeitos interagem em um meio termo, onde o concentrado causa redução no consumo de forragem, mas aumento no consumo total de MS.

Poppi \& McLennan (1995) comentam que, na ausência de substituição, quando $1,2 \mathrm{~kg}$ de grão é fornecido poderá ocorrer aumento de $150 \mathrm{~g}$ de proteína microbiana. Nesse caso, o consumo de energia adicional seria suficiente para aumentar o ganho de peso em $250 \mathrm{~g} /$ dia. Dessa forma, fica difícil prever se o aumento de desempenho, quando ocorre, é devido ao fornecimento de energia ou ao aumento de produção da proteína microbiana.

Devido a essa taxa de substituição, a suplementação energética pode ser menos vantajosa que a protéica, uma vez que essa última provoca aumento de consumo de MS. Paterson et al. (1994) citam que a suplementação com farelo de algodão provocou aumento de ganho de peso de $15 \%$ para novilhos em pastagens de trigo, enquanto que a suplementação energética, de apenas $4 \%$.

Em pastagens temperadas, caracterizadas por altos teores de proteína e alta digestibilidade da $\mathrm{MO}$, parece estar claro que o limitante para o desempenho animal é a deficiência de energia. Porém, suplementações com grãos para vacas em lactação não mostram resultados econômicos devido aos pequenos aumentos da produção de leite.

Kolver et al. (1998), avaliando o programa Cornell para dietas de vacas em lactação sob pastejo, demonstram que suplementações com milho acima de $20 \%$ da MS da dieta não causam aumento de produção de leite, e que dietas com nível de grão maior do que esse, apresentam limitação de produção devido à deficiência em aminoácidos. Suplementações com aminoácidos em dietas com níveis abaixo de $20 \%$ de grão, responderam mais à produção que a própria adição de grão. Desse modo, pode-se 
deduzir que ocorrem grandes perdas de proteína no rúmen e que a proteína microbiana não é suficiente para suprir os aminoácidos, mesmo tendo um excelente perfil desses.

Poppi et al. (1988) demonstraram deficiência de 6 aminoácidos (metionina, lisina, histidina, arginina, treonina e cisteína), quando avaliaram o ganho de peso de ovelhas pastejando forragem com $20 \%$ à $30 \%$ de proteína, comparando com a adição de farinha de peixe ou infusão no abomaso de metionina e lisina. 


\section{AVALIAÇÃO DA QUALIDADE NUTRICIONAL DO CAPIM TANZÂNIA PASTEJADO EM ÁREA IRRIGADA SOB TRÊS NÍVEIS DE RESÍDUO PÓS- PASTEJO.}

\section{Resumo}

Amostras simulando o pastejo de capim Tanzânia (Panicum maximum Jacq.) irrigado sob três resíduo pós-pastejo $(\mathrm{T} 1=$ baixo; $\mathrm{T} 2=$ médio; $\mathrm{T} 3=$ alto $)$ foram coletadas ao longo de um ano e analisadas para a determinação da composição protéica e dos carboidratos, e das frações protéicas e carboidratos (CNCPS). O teor de NDT também foi calculado. Não foi encontrada diferença entre os tratamentos ao longo do ano. Os maiores teores de FDN (68,3 a 64,5\%) e FDA (34,89 a 33,18\%) ocorreram no período de primavera/verão. A lignina apresentou maiores proporções no inverno $(4,68$ a 4,10), o que provocou variação na fração $\mathrm{C}$ dos carboidratos (14,14 a 23,21 \%CT). O NDT variou entre 55,26 e 59,31\%. O teor de PB teve tendência de aumento ao longo do ano, variando de 11,29 a 14,61\%. Os teores de $\mathrm{NnP}$ variaram entre 18,23 e 28,77\% PB, sendo menor para os pastejos de primavera/verão. O Nsol variou de 24,97 a 35,97 \% PB. A fração nFDN foi em média de 49,11 \%PB. Para o nFDA, a variação foi de 6,48 e 11,94 $\%$ PB. A menor qualidade da planta foi entre julho a setembro, podendo estar relacionado a menor renovação de tecidos durante o período de inverno e ao acúmulo de perfilhos florescidos. A maior proporção do $\mathrm{N}$ se encontra na parede celular (fração B3) e foi em média de $40 \% \mathrm{~PB}$, indicando que essa fração deve ter prioridade de estudo no tocante a cinética de degradação ruminal.

\section{Summary}


The objective of this work was to determine the chemical composition of irrigated Tanzania grass (Panicum maximum Jacq.) and to validate the Cornell system. Simulated-grazed samples were collected on three periods of the year (spring, summer and fall, totaling 10 grazing cycles) on irrigated paddocks, rotationally grazed to three post grazing green dry matter residues $(\mathrm{T} 1=$ low, $\mathrm{T} 2=$ medium and $\mathrm{T} 3=$ high $)$. Although there were no statistical differences imposed by the treatments during the year, the NDF and ADF showed higher values ( $\mathrm{P}<.05)$ in the spring/summer, and lignin in the winter $(\mathrm{P}<.05)$ grazing cycles. Along the year the carbohydrate $\mathrm{C}$ fraction, TDN and $\mathrm{CP}$ varied from 14.14 to $23.21 \%, 55.26$ to $59.31 \%$ and 11.29 to $14.61 \%$, respectively. The Nsol, NNP and nADF (as CP\%) varied from 18.23 to $28.77 \%, 24.97$ to $35.97 \%$ and $6.48 \%$ to $11.94 \%$, respectively. The average $\mathrm{nFDN}$ (as CP\%) was $49.11 \%$. From July to September forage quality was the lowest, probably due to the slowest tissue replenishment and flowering tillers' accumulation. The $\mathrm{N}$ largest proportion (average of $40 \%$ of the CP fraction) was recovered in the cell wall, specifically in the B3 fraction, which should be the most important fraction on ruminal fermentation kinetics studies.

\subsection{Introdução}

A qualidade alimentar de uma forragem envolve o seu potencial de consumo e sua qualidade nutricional. Avaliar a qualidade nutricional de uma forragem significa detalhar a composição de sua parede celular, uma vez que este é o principal componente das plantas tropicais. Além da parede celular, a proteína é outra porção importante a ser detalhada, pois interfere diretamente na fermentação ruminal e na produção da proteína microbiana.

A estacionalidade da produção forrageira no Brasil Central é um fenômeno conhecido e estudado, e pode ser resumido como uma menor produção de forragem entre os meses de maio a outubro. Isso ocorre devido à menor precipitação pluvial nessa época, que também coincide com menores temperaturas e menor luminosidade. No entanto, também existe a estacionalidade de produção causada pelas características fisiológicas das plantas. A maior parte das plantas tropicais apresenta uma fase reprodutiva, provocada em resposta à redução no fotoperíodo. No caso do capim 
Tanzânia, a ocorrência de seu florescimento se dá após abril, quando o fotoperíodo passa a ser menor que 12 horas.

Ocorrendo o florescimento a planta reduz sua produção e perde qualidade, pois ocorre o aumento da relação haste/folha (Santos et al., 1999). Entretanto, o florescimento das plantas pode também estar associado a outras características climáticas, como o hidroperíodo. Sendo assim, plantas irrigadas teriam comportamento diferenciado de florescimento que plantas de sequeiro e isso provocaria uma outra tendência na variação da qualidade dessas plantas.

Estresse hídrico promove melhoria na qualidade da forragem, pois aumenta a digestibilidade da MS e reduz a relação haste/folha (Vough et al., 1971; Halim et al., 1989). No entanto, em condições de Brasil Central o efeito do florescimento parece ser maior que o efeito do estresse hídrico, pois a qualidade da planta é reduzida sensivelmente no período de inverno (Santos, 1997).

Por outro lado, períodos prolongados de estresse hídrico podem promover o aumento da espessura de células do esclerênquima (Paciullo, et al., 1999), reduzindo o ataque de microorganismos (Wilson \& Mertens, 1995).

A busca por maiores produtividades em pecuária esbarra no melhor aproveitamento das altas produções que podem ser alcançadas com as gramíneas tropicais. Pastagens manejadas em menores alturas apresentam menores perdas (Hillenshein, 1987) e, portanto, são melhor aproveitadas pelos animais, o que provoca maior eficiência de pastejo, quando comparadas às pastagens manejadas com maiores resíduos pós-pastejo. No entanto, pastagens manejadas com menores resíduos póspastejo podem proporcionar menor desempenho animal, pois, nesse caso, os animais apresentam maior dificuldade de apreensão da planta, o que reduz o consumo de forragem (Burlison, et al., 1991).

Por outro lado, as plantas manejadas com menores resíduos podem apresentar melhor qualidade nutricional, pois apresentam maior renovação de tecidos e, com isso, podem proporcionar ao animal em pastejo dietas de melhor qualidade (Santos, 2001).

Plantas de Tanzânia manejadas em resíduos mais baixos também podem apresentar melhor qualidade, devido à maior proporção de folhas. Intensidades de pastejo maiores promoveram maior proporção de folhas e maior proporção de folhas novas que os tratamentos com intensidades intermediária e baixa (Aguiar et al., 2001). 
Apesar de plantas manejadas em maiores alturas poderem apresentar pior qualidade, esse efeito pode ser minimizada pelos animais, pois, nesse caso, esses têm alta capacidade de selecionar as melhores partes da forragem.

Pastagens de Tanzânia manejadas em alturas de 25, 44, 52 e $75 \mathrm{~cm}$, apresentaram, nas menores alturas de pastejo, maior teor de proteína, menores teores de FDN e FDA e maior digestibilidade da matéria seca. Entretanto, ao longo das coletas, entre janeiro e maio, houve redução da digestibilidade da forragem e essa foi melhor explicada pela ordem da coleta do que pela altura da planta (Rego et al., 2001).

O surgimento do programa de Cornell (Sniffen et al., 1992; Fox et al., 1992, Russel, et al., 1992) demonstrou a necessidade de uma melhor caracterização dos alimentos. Esse programa nutricional parte de um modelo dinâmico que leva em consideração a interação dos diferentes componentes dos alimentos, e tem por objetivo adequar a digestão ruminal dos carboidratos e das proteínas, visando maximizar a produção microbiana, a redução das perdas do nitrogênio pelo animal e estimar o escape ruminal de nutrientes.

Sniffen et al. (1992) dividem a proteína das plantas em cinco frações. A parte solúvel da proteína é dividida em fração A e B1. A fração A, é o nitrogênio não protéico $(\mathrm{NnP})$, essa é de alta digestibilidade no rúmen. O restante da fração solúvel (B1) é uma parte da proteína verdadeira, que também tem rápida degradação ruminal. A fração $\mathrm{C}$ corresponde à proteína indisponível e é a parte da proteína contida na FDA (nFDA). Está associada com lignina, formando complexos de tanino e produtos da reação de Maillard que são altamente resistentes a degradação microbiana e enzimática.

Existe uma fração do nitrogênio contido na FDN, designada de nFDN. A subtração do nFDA do nFDN é uma outra forma da proteína na planta. Essa estaria disponível, porém com uma taxa de degradação muito lenta, é a fração B3 (Sniffen et al., 1992). A última fração, a B2, apresenta taxa de degradação média, é a fração da proteína que não é solúvel, não faz parte da parede celular e também não é NnP.

Os teores de nitrogênio ligados aos compostos da parede celular tendem a aumentar com a idade fisiológica da planta, principalmente, aquela fração ligada a FDA. Lima et al. (1999) encontraram uma redução linear na fração da proteína de lenta degradação (fração B3) com a maturidade de plantas de Tifton-85 (Cynodon dactylon), 
Bahia (Paspalum notatum) e Floralta (Hemarthria altissima). Essa redução foi em detrimento do aumento da fração C.

As plantas apresentam uma concentração ótima de $\mathrm{N}$ para a fotossíntese. Nas plantas C4 essa concentração é maior que para as plantas $\mathrm{C} 3$. O teor de $\mathrm{NnP}$ pode estar associado à adubação nitrogenada. Estando a planta com nível ótimo da $[\mathrm{N}]$, o aumento no fornecimento de $\mathrm{N}$, irá determinar um consumo de luxo e, consequentemente, aumento do NnP (Cilliers et al., 1997).

Malafaia et al. (1997), encontraram para 4 plantas tropicais (Tifton-85, Capim-elefante, Brachiaria brizantha e Brachiaria decumbens) valores para a fração C variando entre 11,66 e 27,73\% PB. A fração A variou de 11,58 a 32,28\% PB, enquanto que as frações B1, B2 e B3 tiveram variações entre 0,58 e 4,54; 32,97 e 43,62; 17,55 e $34,17 \%$ PB, respectivamente. Nesse trabalho a Brachiaria brizantha apresentou a pior qualidade da proteína (a soma das frações B3 e C, foi de 51,90\% da PB), enquanto que, a Brachiaria decumbens apresentou a menor proporção da proteína na forma das frações C e B3 (a soma de 29,21\% da PB). A Brachiaria decumbens também apresentou o maior valor para a fração A, 32,28\% e a Brachiaria brizantha o menor, 11,58\% da PB.

O fracionamento da proteína pode ter influência da espécie forrageira, no entanto, parece ser mais dependente do manejo, idade fisiológica e adubação nitrogenada.

Os carboidratos também são fracionados. A porção C é a parte indisponível, a fração A são os carboidratos solúveis, a fração B1, o amido, e a fração B2, a parte potencialmente degradável da parede celular.

As gramíneas tropicais apresentam baixos teores de carboidratos solúveis e amido, frações A e B1, raramente superiores a 20\% dos carboidratos totais (CT) (Vieira, et al., 2000b). A fração indisponível, C, é dependente do teor de lignina, portanto, plantas de idade fisiológica mais avançadas apresentam maiores teores dessa fração. $\mathrm{O}$ aumento da fração $\mathrm{C}$, promove redução da fração potencialmente degradável (B2) (Caballero, et al., 2001).

Desse modo, torna-se importante detalhar a qualidade nutricional de plantas de capim Tanzânia manejadas sob três resíduos pós-pastejo em uma área irrigada ao longo de um ano. 


\subsection{Material e Métodos}

O experimento foi conduzido na Fazenda Areão da Escola Superior de Agricultura "Luiz de Queiroz" da Universidade de São Paulo, em Piracicaba, São Paulo ( $22^{0} 42^{\prime} 30^{\prime \prime}$ lat. S; $47^{\circ} 38^{\prime} 00^{\prime \prime}$ long. W; $546 \mathrm{~m}$ altitude). A forragem utilizada foi o capim Tanzânia (Panicum maximum Jacq.) estabelecido em área irrigada através de pivô central. A pastagem foi manejada através de pastejo rotacionado com 33 dias de descanso e três dias de ocupação. Os tratamentos, com quatro repetições, foram constituídos de três níveis de resíduo pós-pastejo, a saber: T1 - Baixo, T2 - Médio e T3 - Alto. Os valores de resíduo pós-pastejo ao longo do ano constam da Tabela 1. Para cada tratamento havia 12 parcelas de $1330 \mathrm{~m}^{2}$ distribuídos em quatro blocos, sendo cada parcela subdividida em três piquetes para facilitar o manejo.

Tabela 1. Resíduo pós-pastejo em quatro épocas do ano para os três níveis de resíduo (T1- Baixo, T2- Médio e T3- Alto).

\begin{tabular}{lllll}
\hline Tratamento & Época 1 & Época 2 & Época 3 & Época 4 \\
\hline & & \multicolumn{2}{c}{ kg MSV/ha } \\
T1 & $1277^{\mathrm{Aab}}$ & $1763^{\mathrm{Aab}}$ & $816^{\mathrm{Ab}}$ & $1210^{\mathrm{Aba}}$ \\
$\mathrm{T} 2$ & $2459^{\mathrm{Ba}}$ & $3346^{\mathrm{Bb}}$ & $2548^{\mathrm{Bab}}$ & $3306^{\mathrm{Bb}}$ \\
$\mathrm{T} 3$ & $3106^{\mathrm{Ca}}$ & $5335^{\mathrm{Cb}}$ & $3113^{\mathrm{Ca}}$ & $5471^{\mathrm{Cb}}$ \\
\hline
\end{tabular}

Época 1 - 29/10/1999 a 14/02/2000

Época 2 - 15/02/2000 a 02/06/2000

Época 3 - 03/06/2000 a 13/08/2000

Época 4 - 18/09/2000 a 29/11/2000

Médias seguidas da mesma letra minúscula na linha ou maiúscula na coluna não diferem significativamente $(\mathrm{P}>0,05)$.

O solo foi corrigido para garantir os seguintes níveis de fertilidade: saturação por bases, $80 \%$; fósforo, $30 \mathrm{mg} / \mathrm{dm}^{3}$; potássio, $5 \%$ da CTC. Imediatamente após cada 
pastejo os piquetes foram adubados com $80 \mathrm{~kg} / \mathrm{ha}$ de $\mathrm{N}$ e $80 \mathrm{~kg} / \mathrm{ha}$ de $\mathrm{K}_{2} \mathrm{O}$ em todos os ciclos de pastejo ao longo de 1 ano.

A pastagem foi formada em abril de 1999. O primeiro pastejo foi em agosto de 1999, após esse, mais dois pastejos se sucederam, os quais foram denominados de pastejo de estabelecimento dos tratamentos. O primeiro pastejo que fez parte efetiva do levantamento de dados, se deu no final do mês de outubro de 1999, o décimo primeiro pastejo teve seu término no final de novembro de 2000 (Tabela 2), esse pastejo foi o último do levantamento de dados. O pastejo de número 9 não foi realizado, pois nesse período, devido à ocorrência de uma geada e consequentemente da baixa produtividade da forragem, não foi possível a manutenção dos animais na área. No entanto, nesse pastejo, prosseguiu-se as medidas e amostragens da forragem, como coleta de amostras simulando o pastejo e avaliação da oferta forrageira.

Tabela 2. Seqüência dos ciclos de pastejos e suas datas de início e término.

\begin{tabular}{ccc}
\hline Ciclos de pastejos & Início do pastejo & Término do pastejo \\
\hline 1 & $29 / 10 / 99$ & $04 / 12 / 99$ \\
2 & $04 / 12 / 99$ & $09 / 01 / 00$ \\
3 & $09 / 01 / 00$ & $14 / 02 / 00$ \\
4 & $14 / 02 / 00$ & $21 / 03 / 00$ \\
5 & $21 / 03 / 00$ & $26 / 04 / 00$ \\
6 & $26 / 04 / 00$ & $02 / 06 / 00$ \\
7 & $02 / 06 / 00$ & $08 / 07 / 00$ \\
8 & $08 / 07 / 00$ & $13 / 08 / 00$ \\
9 & $13 / 08 / 00$ & $18 / 09 / 00$ \\
11 & $18 / 09 / 00$ & $24 / 10 / 00$ \\
\hline
\end{tabular}

As amostras foram coletadas simulando o pastejo dos animais. Foram coletadas de cada tratamento em cada bloco ao longo de 10 ciclos de pastejo (Pastejo 1 
ao Pastejo 10). Como os blocos eram pastejados em sequência, a freqüência de amostragem foi de 9 dias.

As condições climáticas durante o período experimental constam da Tabela 3.

Tabela 3. Condições climáticas da área experimental ao longo do período de coleta de dados.

\begin{tabular}{lcccc}
\hline Ano mês & $\begin{array}{c}\text { Radiação Global } \\
\text { Cal/cm }{ }^{2} \cdot d\end{array}$ & $\begin{array}{c}\text { Insolação } \\
\text { h/dia }\end{array}$ & $\begin{array}{c}\text { Temperatura } \\
\text { máxima }\left({ }^{\circ} \mathrm{C}\right)\end{array}$ & $\begin{array}{c}\text { Temperatura } \\
\text { mínima }\left({ }^{\circ} \mathrm{C}\right)\end{array}$ \\
\hline Out 1999 & 454 & 6,98 & 28,48 & 15,36 \\
Nov 1999 & 478 & 7,04 & 29,47 & 15,70 \\
Dez 1999 & 508 & 7,23 & 30,56 & 18,99 \\
Jan 2000 & 464 & 6,37 & 30,22 & 19,09 \\
Fev 2000 & 450 & 5,49 & 29,92 & 19,24 \\
Mar 2000 & 411 & 5,42 & 29,68 & 18,53 \\
Abr 2000 & 451 & 9,08 & 29,36 & 14,48 \\
Mai 2000 & 347 & 7,36 & 26,64 & 11,19 \\
Jun 2000 & 304 & 6,68 & 27,16 & 11,36 \\
Jul 2000 & 320 & 6,47 & 24,71 & 8,83 \\
Ago 2000 & 324 & 5,74 & 26,53 & 12,50 \\
Set 2000 & 396 & 6,17 & 27,20 & 15,10 \\
Out 2000 & 480 & 7,20 & 32,07 & 17,99 \\
Nov 2000 & 465 & 6,79 & 29,82 & 17,72 \\
\hline
\end{tabular}

Análise bromatológica

O material colhido através do pastejo simulado foi analisado para as frações protéicas e para composição da parede celular. As análises seguiram as metodologias de Goering \& Van Soest (1970) e Van Soest et al. (1991), para as determinações dos componentes da parede celular. Para as frações nitrogenadas seguiu-se as metodologias 
de Krishnamoorthy et al. (1982) e Licitra et al. (1996). Nesses materiais foram determinados: FDN, FDA, Lignina, PB, nFDN, nFDA, Nsol, NnP, MM.

As frações FDN e FDA foram determinadas através do equipamento Ankon (Ankon 200 Fiber Analyser da Ankon Technology Corporation). Nessas determinações foi adicionado o sulfito de sódio, com o objetivo de solubilizar a proteína aderida à parede celular (Mertens, 1998).

A lignina foi determinada com a adição de ácido sulfúrico $72 \%$ no resíduo insolúvel da determinação da FDA (Van Soest, 1982).

Para a determinação da proteína total utilizou-se o equipamento da Leco FP 528 (Leco Corporation, St. Joseph, MI, EUA). As determinações das frações nitrogenadas, nFDN, nFDA, Nsol e NnP, foram realizadas em Macro Kjedal. A FDN e FDA, quando direcionadas para a determinação do teor de nitrogênio nelas contido foram determinadas em equipamento convencional de fibra, seguindo a metodologia de Goering \& Van Soest (1970), sendo que para essas determinações não foi usado o sulfito de sódio.

Foram calculadas as frações dos carboidratos e da proteína seguindo a metodologia adotada para o programa de Cornell (CNCPS) (Sniffen et al., 1992), onde:

Frações carboidratos:

A - carboidratos solúveis

B1 - amido e pectina

B2 - carboidratos estruturais disponíveis

C - carboidratos indisponíveis

As equações usadas para determinar cada fração seguem:

$\mathrm{CT}(\% \mathrm{MS})=100-\mathrm{PB}-\mathrm{EE}-\operatorname{cinza}$

$\mathrm{C}(\% \mathrm{CT})=100 *[\mathrm{FDN} * 0,01 \mathrm{LIG}(\% \mathrm{FDN}) * 2,4] / \mathrm{CT}(\% \mathrm{MS})$

B2 $(\% \mathrm{CT})=100 *\{[\mathrm{FDN}-\operatorname{nFDN}(\% \mathrm{~PB}) * 0,01 * \mathrm{~PB}-$ $\mathrm{FDN} * 0,01 * \mathrm{LIG}(\% \mathrm{FDN}) * 2,4] / \mathrm{CT}\}$

$\mathrm{B} 1(\% \mathrm{CT})=\mathrm{AMIDO}(\% \mathrm{CNE}) *(100-\mathrm{B} 2-\mathrm{C}) / 100$

$\mathrm{CNE}=100-\mathrm{B} 2-\mathrm{C}$ 
$\mathrm{A}(\% \mathrm{CT})=\mathrm{AÇÚCAR}(\% \mathrm{CNE}) *(100-\mathrm{B} 2-\mathrm{C}) / 100$

Fração proteína:

$\mathrm{A}=$ nitrogênio não protéico

B1 = proteína rapidamente degradável; Proteína Solúvel - A

B3 = lenta degradação; nFDN - nFDA

B2 = degradação intermediária; 100 - A - B1 - B3 - C

$\mathrm{C}=\mathrm{nFDA}$

O NDT foi estimado pela equação de Weiss (1993), sendo determinado para MS e para MO.

\section{Análise estatística}

A análise estatística foi realizada segundo um modelo de blocos completos com medidas repetidas no tempo. As análises foram feitas usando o programa Genstat 5.0 (Genstat. 1999).

\subsection{Resultados e Discussão}

Para todos os parâmetros analisados, tanto da parte nitrogenada quanto da parte dos carboidratos, não foi encontrada diferença entre os tratamentos nos ciclos de pastejos avaliados.

Os maiores teores de FDN foram observados nos primeiros períodos (Figura 1), que correspondem ao período de primavera e verão, enquanto que os menores foram para os meses de agosto e setembro (ciclos de pastejos 8 e 9).

Os valores de FDN, que variaram entre 62,79 e 68,33\% MS (Figura 1), estão de acordo com os dados de literatura para o capim Tanzânia (Rego et al., 2001). No trabalho de Rego et al. (2001), os valores de FDN variaram entre 61,47 e 73,96\% MS, esses valores representavam diferentes extratos da planta em 4 alturas de pastejo. No 
entanto, ao se verificar os valores que seriam correspondentes às amostras de pastejo simulado (estratos superiores), os teores de FDN variaram entre 63,58 e 69,04\% MS.

Rego et al. (2001), no entanto, verificaram que o pastejo do capim Tanzânia em maiores alturas proporcionou alimentos de pior qualidade, evidenciado, entre outros parâmetros, pelo maior teor de FDN.

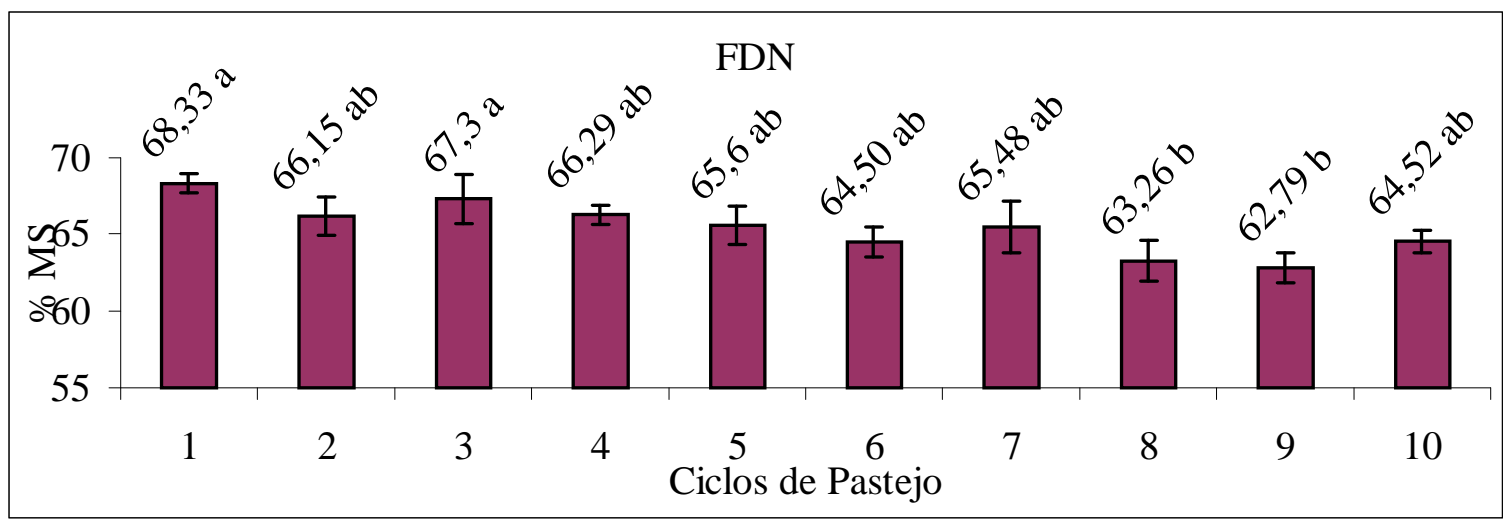

Figura 1- Teor de FDN em \% da matéria seca de amostras de pastejo simulado de capim Tanzânia (Panicum maximum Jacq.), médias de três níveis de resíduo póspastejo (Baixo, Médio e Alto) ao longo de 10 ciclos de pastejos. Médias seguidas da mesma letra não diferem significativamente pelo teste de Tukey $(\mathrm{P}>0,05)$. Barras indicam o erro padrão da média.

Maiores teores de FDN foram também observados por Carnevalli et al. (1999), quando pastagens de Tifton-85 foram manejadas a maiores alturas. Na primavera para 15 e $20 \mathrm{~cm}$ os teores de FDN foram mais altos que para $5 \mathrm{~cm}$. Enquanto que no verão o teor de FDN foi maior a $20 \mathrm{~cm}$ comparado às alturas de 10 e $15 \mathrm{~cm}$ e para $5 \mathrm{~cm}$ a FDN foi menor que para as outras alturas de pastejo.

Valores semelhantes podem ser encontrados em Silva (1993) para amostras de Capim-elefante pastejado sob três pressões de pastejo, onde os menores teores de FDN foram verificados nas pastagens submetidas à alta pressão de pastejo.

O motivo de não ter havido maiores teores de FDN no tratamento de menor intensidade de pastejo (T3), pode estar associado à alta taxa de renovação de tecido dessas pastagens, proporcionado, provavelmente, pela irrigação e pela elevada dosagem 
de nitrogênio aplicada a cada pastejo $(80 \mathrm{~kg} / \mathrm{ha})$ em pastagem recém estabelecida. Plantas manejadas em maiores alturas tendem a apresentar menor densidade de perfilhos, no entanto, o que se observou nos seis primeiros ciclos de pastejo, foi semelhança na densidade de perfilhos entre os tratamentos ( Santos $\left.^{3}\right)$.

Por outro lado, a relação folha/haste foi menor para o T3 comparado ao T1, no entanto, o efeito de ciclos de pastejo foi muito maior que de tratamentos. Em média a porcentagem de folhas da planta toda foi de 56,16, 50,62 e 50,51\%, respectivamente para T1, T2 e T3. Indicando que a capacidade dos animais selecionarem folhas nos tratamentos de maior oferta de forragem (T3) é maior. A maior seletividade dos animais pela forragem pode ter suplantado uma eventual pior qualidade da planta nos tratamentos 2 e 3 .

A amostra de pastejo simulado deve ser o mais semelhante possível da dieta dos animais. Em pastagens manejadas com elevadas taxas de lotação, os erros na amostragem do pastejo simulado ficam minimizados, pois, apesar de existir seletividade, os animais fazem o pastejo por estratos horizontais, o que facilita a amostragem. Por outro lado, o hábito de pastejo dos animais deve ser observado, pois a metodologia de se fazer a amostragem em extratos, mas alterando a arquitetura da planta, pode levar a erros na avaliação da qualidade da planta (Molan et al., 1999).

A proporção de FDN em uma forragem é importante não só para a avaliação de sua qualidade nutricional, mas também pelo fato da FDN estar relacionada com consumo máximo de matéria seca (Mertens, 1994). Desse modo, plantas com teores maiores de FDN, teriam menor potencial de consumo.

Os teores de FDA (Figura 2) seguiram as mesmas tendências que a FDN, apresentaram maiores concentrações nos períodos de outono (ciclos de pastejos 3 e 4), no entanto, não foram diferentes significativamente das amostras de verão e primavera. Menores teores da FDA foram observados entre julho a setembro (ciclos de pastejos $8 \mathrm{e}$

${ }^{3}$ SANTOS, P.M. Controle do desenvolvimento das hastes no capim Tanzânia: um desafio. Piracicaba. Tese (Doutorado). Escola Superior de Agricultura "Luiz de Queiroz", Universidade de São Paulo (em elaboração). 
9) (Figura 2). Os teores de FDA variaram entre 32,55 e 34,89\% da MS. Esses teores de FDA são compatíveis com análises da parede celular de outras gramíneas e também do Tanzânia (Balsalobre, 1996; Rego et al., 2001). Teores de FDA acima desses, podendo atingir valores superiores a 40\% MS, são encontrados somente em plantas com idade fisiológica bem avançada.

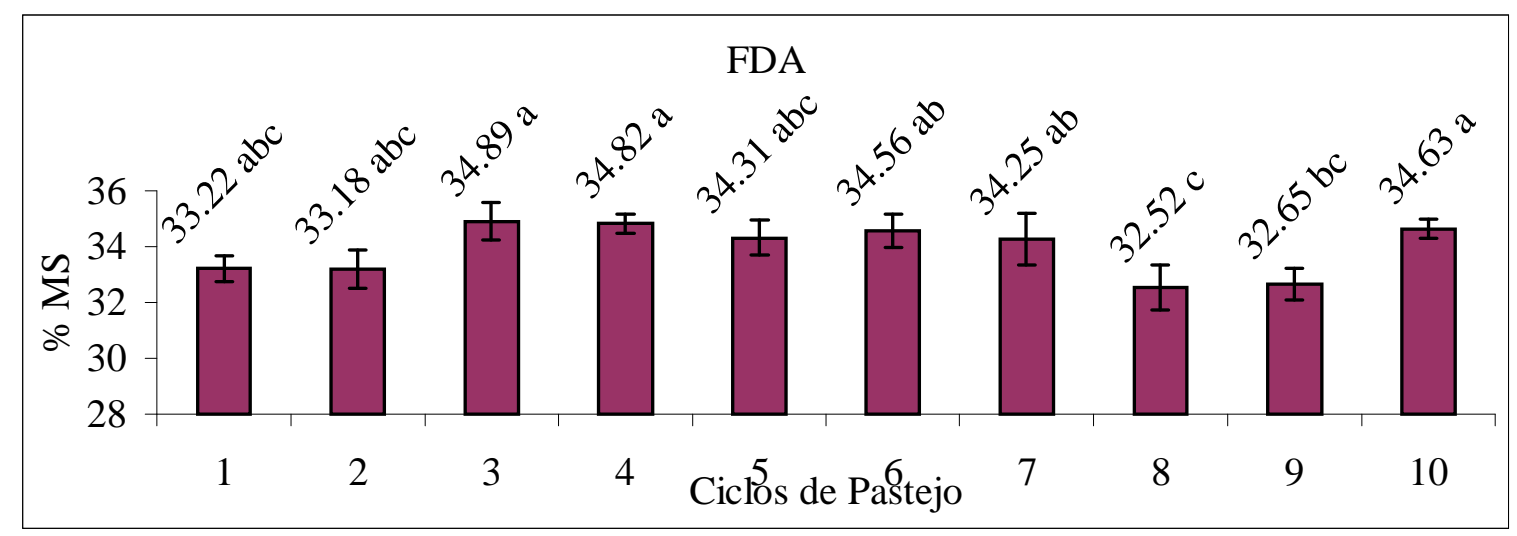

Figura 2- Teor de FDA em \% da matéria seca de amostras de pastejo simulado de capim Tanzânia (Panicum maximum Jacq.), médias de três níveis de resíduo póspastejo (Baixo, Médio e Alto) ao longo de 10 ciclos de pastejos. Médias seguidas da mesma letra não diferem significativamente pelo teste de Tukey $(\mathrm{P}>0,05)$. Barras indicam o erro padrão da média.

Os teores de lignina, no entanto, têm tendências diferenciadas em relação a FDA e a FDN. Nos ciclos de pastejos iniciais (1 e 2) os teores são menores em relação aos ciclos 6, 7, 8 e 9 (Figura 3). Os teores de lignina tiveram variação entre 3,10 e 4,68\% MS. Esse comportamento diferenciado dos componentes da parede celular pode promover maior variação em sua qualidade, pois as plantas que apresentaram os menores teores de FDN apresentaram os maiores teores de lignina. Isso pode ser evidenciado quando se observa o comportamento da fração C (Figura 4), essa fração corresponde a parte indisponível do total de carboidratos da planta (CT) (Sniffen et al., 1992). 
A fração C foi menor para o ciclo de pastejo $1(14,14 \%$ CT) apesar de não ter diferença significativa dos teores encontrados para os ciclos de pastejo 2,4 e 5 . Os maiores valores para a fração $C$ foram encontrados para os ciclos 7 e $8(22,80$ e 23,21\% $\mathrm{CT}$, respectivamente), que também não foram diferentes significativamente em relação aos teores encontrados nos ciclos 6, 9 e 10. De modo geral, as amostras representativas dos meses de inverno apresentaram maiores teores de carboidratos indisponíveis que as amostras de verão.

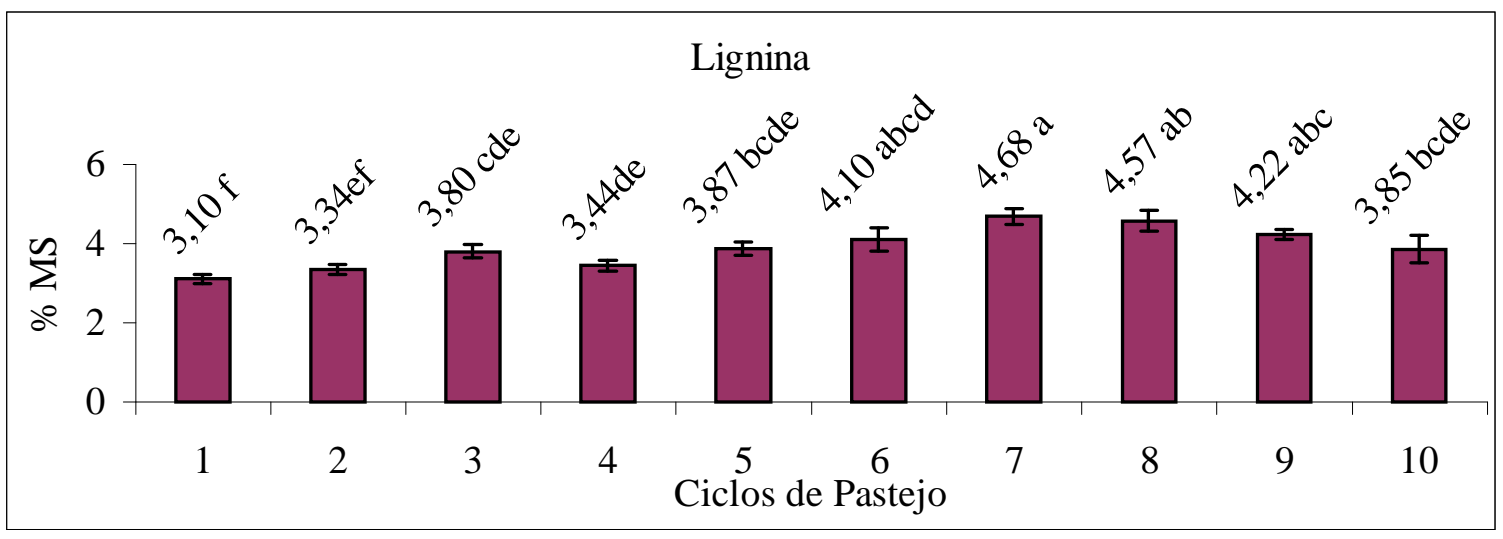

Figura 3- Teor de lignina em $\%$ da matéria seca de amostras de pastejo simulado de capim Tanzânia (Panicum maximum Jacq.), médias de níveis de resíduo pós-pastejo (Baixo, Médio e Alto) ao longo de 10 ciclos de pastejos. Médias seguidas da mesma letra não diferem significativamente pelo teste de Tukey $(\mathrm{P}>0,05)$. Barras indicam o erro padrão da média.

A pior qualidade da fração carboidrato após o mês de maio (ciclo 6), pode ser explicada pelo florescimento das plantas. Ao longo do ano vários períodos de florescimento foram observados, visualmente o maior foi no mês de abril (pastejo 5) (Santos ${ }^{1}$ ), no entanto, no mês de junho (pastejo 7) boa parte dos perfilhos floresceu novamente. Assim, pode ter havido acúmulo de perfilhos florescidos em momentos diferentes, pois é provável que nessa época do ano (outono/inverno), a renovação de tecido tenha se reduzido e os perfilhos sobrevivido por mais tempo, o que provocou maior lignificação e maior teor da fração $\mathrm{C}$ nesses meses (julho/agosto). 


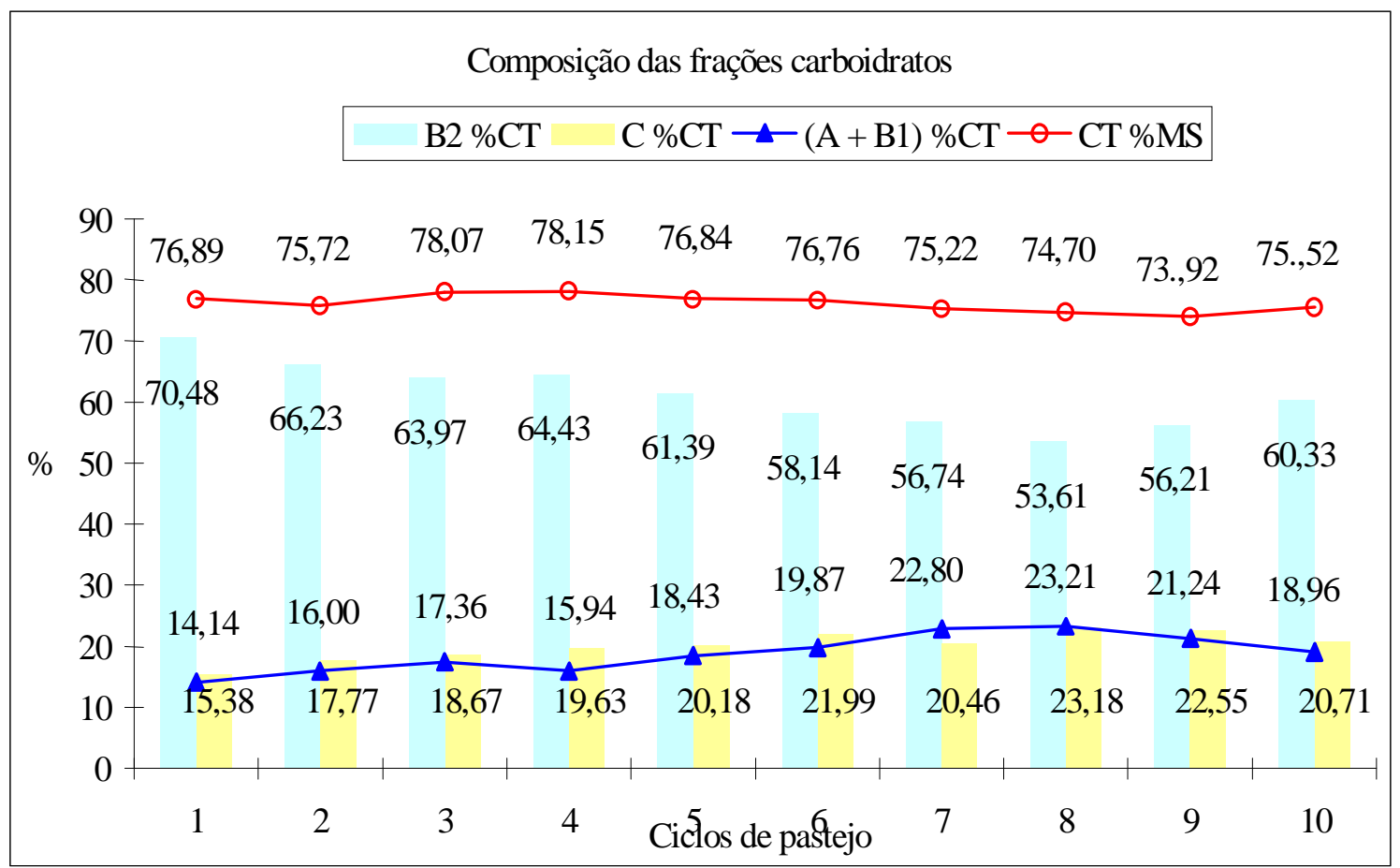

Figura 4- Composição dos carboidratos em \% dos carboidratos totais (CT) e dos carboidratos totais em \% MS de amostras de pastejo simulado de capim Tanzânia (Panicum maximum Jacq.) para três níveis de resíduo pós-pastejo (Baixo, Médio e Alto) por 1 ano ao longo de 10 ciclos de pastejos.

$\mathrm{O}$ aumento no teor da fração $\mathrm{C}$ dos carboidratos foi em detrimento de uma redução da fração B2 (Figura 4). Para essa, fração os maiores teores foram observados nos ciclos de pastejo iniciais. O maior valor foi de 70,48\% CT (ciclo 1) e o menor de $53,61 \%$ CT (ciclo 8).

Através da Figura 5 é possível verificar que a fração da parede celular que mais sofreu variações foi a hemicelulose, seus valores variaram de 29,89 a 35,11\% MS, que correspondem a variação de 46,33 a 51,38\% da FDN. A celulose, por sua vez, teve uma menor variação, entre 27,95 e 31,09\% MS, correspondendo a 44,08 e 47,73\% da FDN. O coeficiente de variação dessas determinações foi de 5,22 e 3,93\%, respectivamente para hemicelulose e celulose. A hemicelulose, além de ser o 
componente da parede celular que sofre maior variação em seu teor, também é a fração que mais perde digestibilidade com o lignificação (Messman et al., 1991).

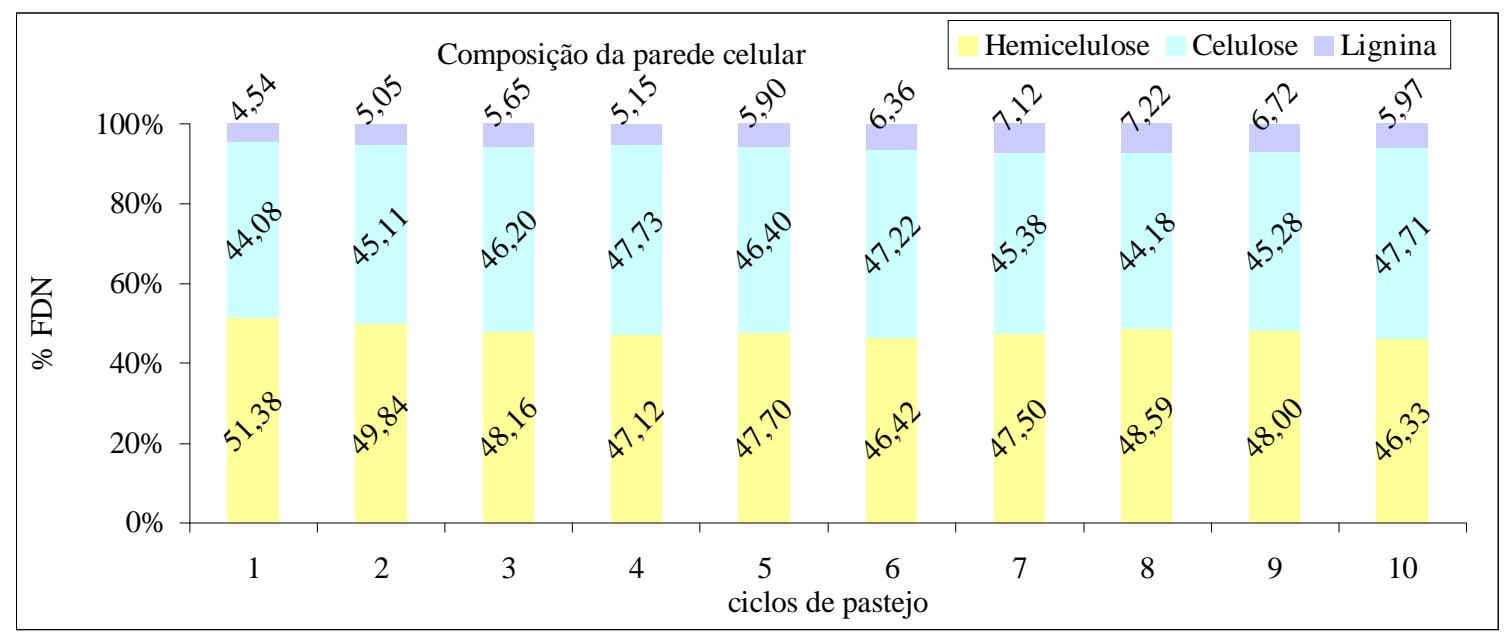

Figura 5- Composição da parede celular em \% da FDN de amostras de pastejo simulado de capim Tanzânia (Panicum maximum Jacq.), médias de três níveis de resíduo pós-pastejo (Baixo, Médio e Alto) por 1 ano ao longo de 10 ciclos de pastejo.

Em plantas tropicais os CT representam a grande proporção das plantas. Neste caso, esses teores variaram entre 74 e $78 \%$ MS (Figura 4), isso significa que a variação na qualidade dessa fração interfere diretamente na disponibilidade de energia para o ruminante. Os cálculos do NDT (Figuras 6 e 7) mostram a tendência de maiores valores nos ciclos em que a fração $\mathrm{C}$ dos carboidratos foi menor. Entretanto, esses ciclos foram os de maiores teores de FDN.

O NDT calculado como porcentagem da matéria seca (Figura 6) teve variação entre 55,26 e 59,31\%. O menor valor foi para o ciclo de pastejo 7. Esse ciclo de pastejo coincide com o maior acúmulo de perfilhos florescidos (observação visual). Enquanto que, os maiores teores de NDT (\% MS) foram para os pastejos correspondentes aos períodos de primavera e verão.

O cálculo do NDT em relação a MO (Figura 7) mostra tendências semelhantes ao NDT com base na MS, no entanto, o cálculo do NDT isolando o efeito da MM, mostra maior evidência nas diferenças dos valores. A menor porcentagem de NDT na 
MO foi para o ciclo 7 e os maiores valores para os ciclos correspondentes aos pastejos de primavera e verão. Os valores variaram entre 62,63 e 65,31\%. As diferenças entre o menor e o maior valor do NDT na base MS foi maior (4,05 pontos percentuais) que para o NDT na MO (2,87 pontos percentuais), no entanto, os coeficientes de variações da fração MO são menores, o que possibilita uma melhor avaliação da qualidade da planta.

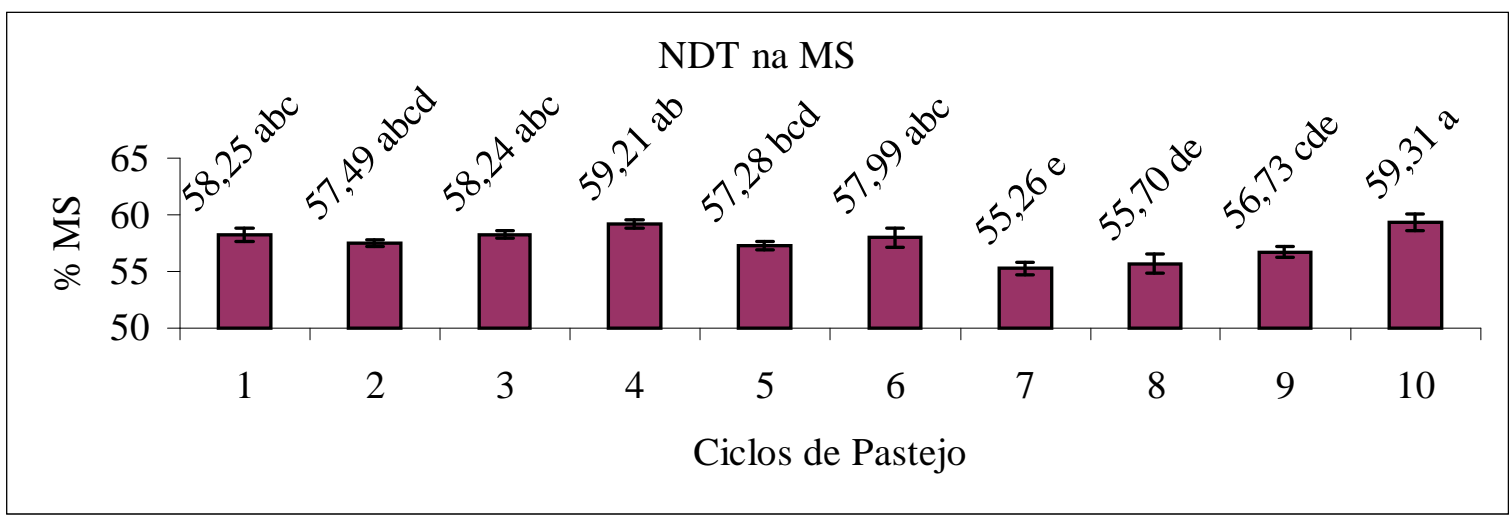

Figura 6- Teor de NDT em \% da matéria seca de amostras de pastejo simulado de capim Tanzânia (Panicum maximum Jacq.) médias de três níveis de resíduo póspastejo (Baixo, Médio e Alto) ao longo de 10 ciclos de pastejos. Médias seguidas da mesma letra não diferem significativamente pelo teste de Tukey $(\mathrm{P}>0,05)$. Barras indicam o erro padrão da média.

A proporção dos carboidratos de rápida degradação ruminal, representada pelas frações A e B1, que correspondem aos carboidratos solúveis e ao amido, compreenderam valores entre 15,38 e 23,18\% CT, com média de 20,05\% (Figura 4). Os teores da soma das frações A e B1 são maiores que os encontrados por Vieira et al. (2000b), que em amostra de pastagens nativas, obtiveram teores de A + B1 entre 11,07 e $15,17 \% \mathrm{CT}$, respectivamente para um período de coleta de seca e de águas. As análises de Vieira et al. (2000b) para as frações de carboidratos de rápida degradação podem ter sido subestimadas, pois foram coletas da extrusa e, nesse caso, esses compostos podem se solubilizar na boca dos animais. 


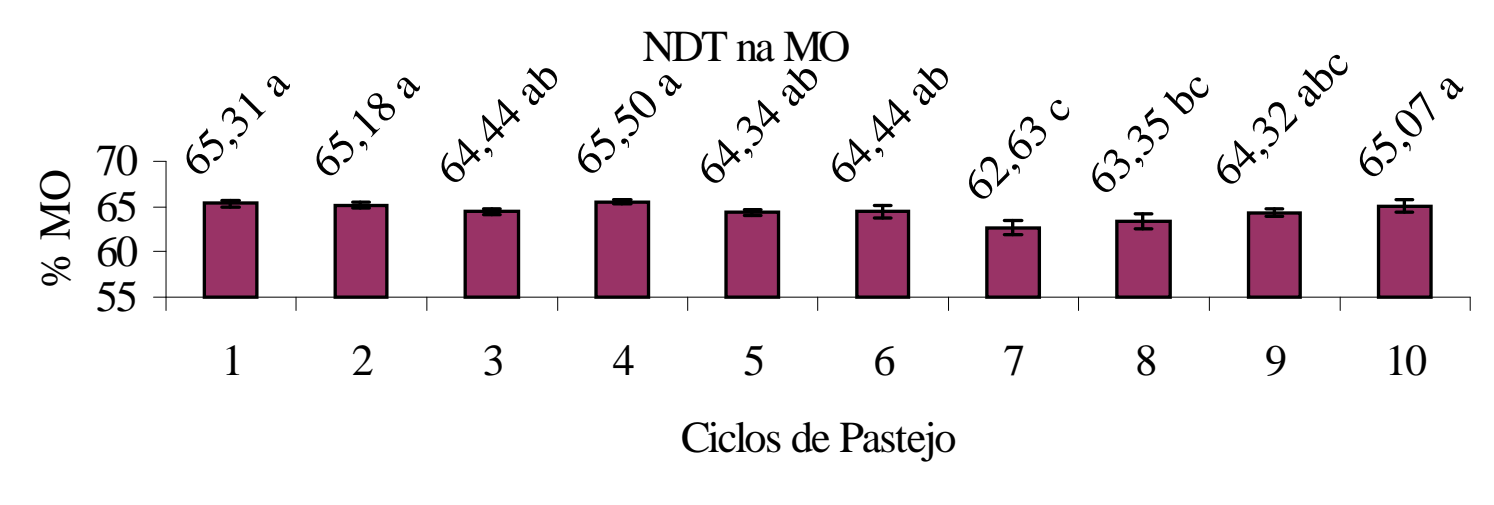

Figura 7- Teor de NDT em \% da matéria orgânica de amostras de pastejo simulado de capim Tanzânia (Panicum maximum Jacq.) médias de três níveis de resíduo pós-pastejo (Baixo, Médio e Alto) ao longo de 10 ciclos de pastejos. Médias seguidas da mesma letra não diferem significativamente pelo teste de Tukey $(\mathrm{P}>0,05)$. Barras indicam o erro padrão da média.

O teor de PB teve tendência de aumento ao longo dos ciclos de pastejos (Figura 8). O menores valores, em torno de 11,50\% MS, foram obtidos nos primeiros 5 ciclos de pastejos, enquanto que, o maior valor foi para o último pastejo, 14,61\% MS. O aumento do valor da proteína ao longo dos ciclos de pastejo, provavelmente, foi devido ao manejo da adubação nitrogenada. Em virtude de se tentar isolar o fator irrigação na produção da forragem, a quantidade de nitrogênio aplicada em cada ciclo de pastejo (80 $\mathrm{kg} \mathrm{N} / \mathrm{ha}$ ) foi a mesma.

Nos ciclos de pastejo de inverno a produção forrageira foi em torno de $50 \%$ da produção de verão (Penati $\left.{ }^{4}\right)$. Portanto, pode-se concluir que, com mais nitrogênio no sistema, houve consumo de luxo desse nutriente e o teor protéico aumentou.

\footnotetext{
${ }^{4}$ PENATI, M. A. Estudo do desempenho animal e produção do capim Tanzânia (Panicum
} maximum Jacq.) em um sistema rotacionado de pastejo sob irrigação em três níveis de resíduo pós-pastejo. Tese (Doutorado). Escola Superior de Agricultura "Luiz de Queiroz", Universidade de São Paulo, 2002. (em elaboração). 


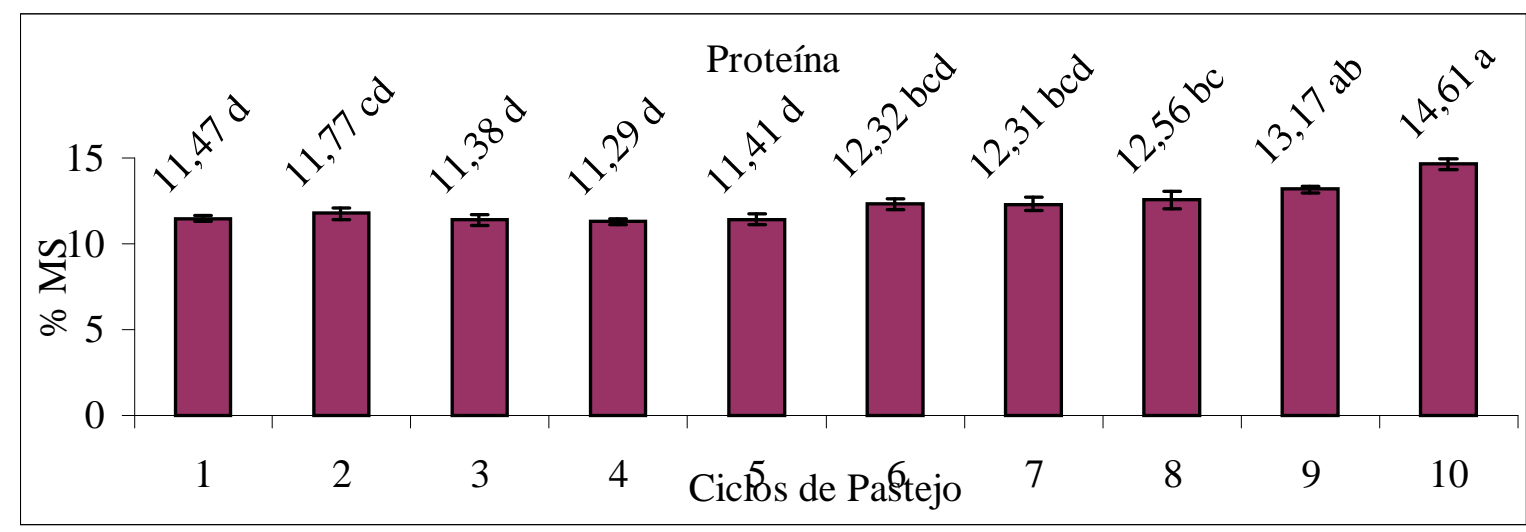

Figura 8- Teor de proteína em \% da matéria seca de amostras de pastejo simulado de capim Tanzânia (Panicum maximum Jacq.), médias de três níveis de resíduo pós-pastejo (Baixo, Médio e Alto) ao longo de 10 ciclos de pastejos. Médias seguidas da mesma letra não diferem significativamente pelo teste de Tukey $(\mathrm{P}>0,05)$. Barras indicam o erro padrão da média.

O provável consumo de luxo pela forragem durante os últimos ciclos de pastejo são evidenciados também pelo aumento nos teores de NnP e Nsol (Figuras 9 e 10). O NnP, corresponde à fração A para o programa de Cornell, enquanto que a subtração do NnP do Nsol, nos indica o valor da fração B1, que teve variação entre 3,92 e 8,03\% da PB (Figura 13). A fração B1 tem pouca importância em plantas forrageiras, pois, sempre representa valores menores que $10 \%$ do total da proteína.

Os teores de $\mathrm{NnP}$ variaram entre 18,23 e $28,77 \%$ da $\mathrm{PB}$, sendo o menor valor para o primeiro ciclo de pastejo e os maiores para os últimos ciclos. O teor de Nsol variou de 24,97 a $35,97 \% \mathrm{~PB}$, portanto o $\mathrm{NnP}$ representa em torno de 75 a $80 \%$ do Nsol.

Sendo a Rubisco uma enzima solúvel, a fração B1 dá uma boa indicação do seu teor. Desse modo, os valores dessa enzima estariam sempre abaixo de $10 \%$ da PB, valor esse semelhante ao de Capim-elefante (Balsalobre, 1996), e outras gramíneas tropicais (Lima et al., 1999 e Malafaia et al., 1997). 


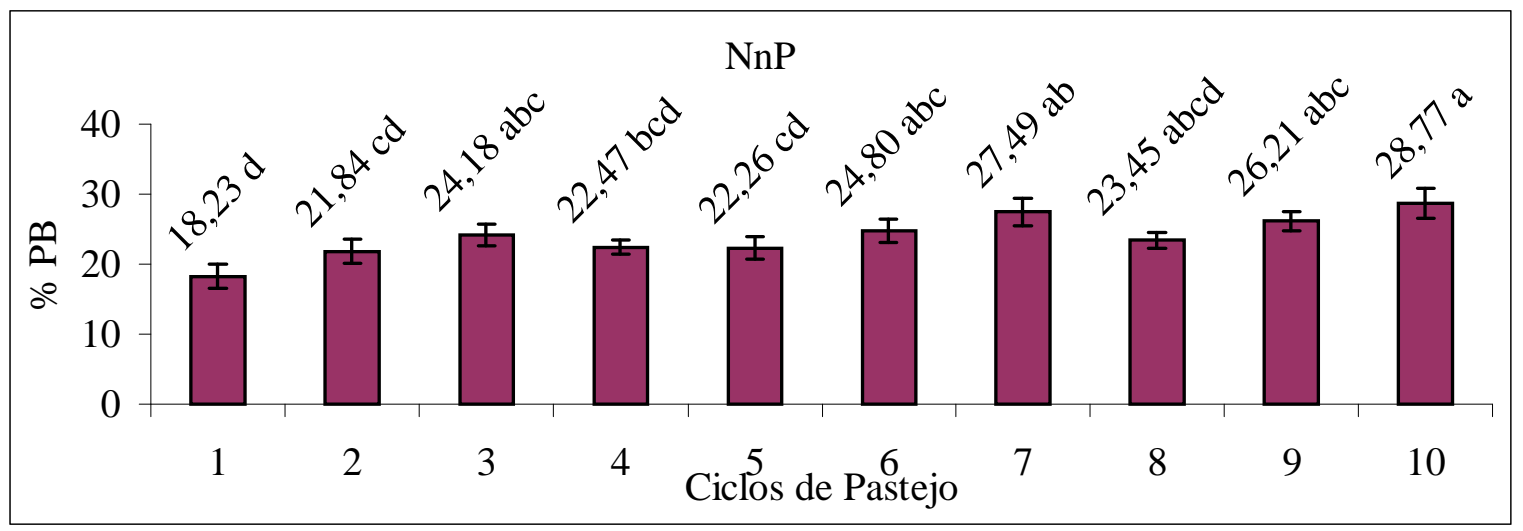

Figura 9- Teor de NnP em \% do nitrogênio total de amostras de pastejo simulado de capim Tanzânia (Panicum maximum Jacq.), médias de três níveis de resíduo pós-pastejo (Baixo, Médio e Alto) ao longo de 10 ciclos de pastejos. Médias seguidas da mesma letra não diferem significativamente pelo teste de Tukey $(\mathrm{P}>0,05)$. Barras indicam o erro padrão da média.

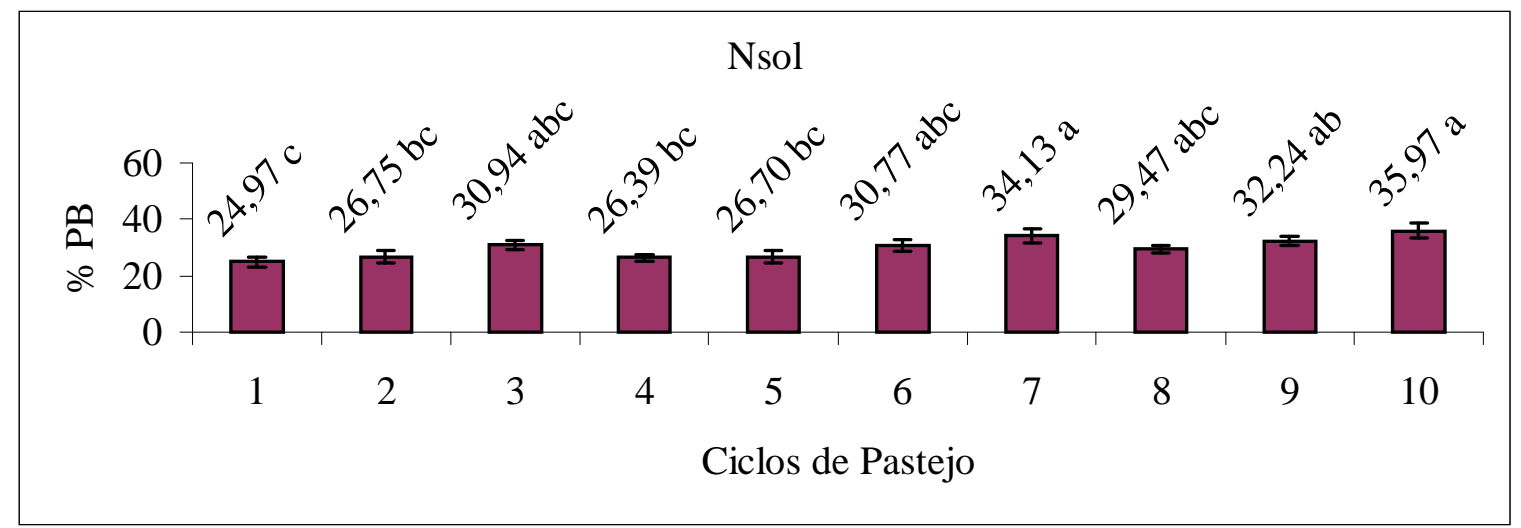

Figura 10- Teor de Nsol em \% do nitrogênio total de amostras de pastejo simulado de capim Tanzânia (Panicum maximum Jacq.), médias de três níveis de resíduo pós-pastejo (Baixo, Médio e Alto) ao longo de 10 ciclos de pastejos. Médias seguidas da mesma letra não diferem significativamente pelo teste de Tukey $(\mathrm{P}>0,05)$. Barras indicam o erro padrão da média.

A fração B2, de degradação lenta, apresentou variação de teores entre 14,96 e 25,16\% PB (Figura 12). Os maiores valores foram encontrados nos ciclos iniciais e o 
menor no último ciclo de pastejo, mostrando que o acúmulo de $\mathrm{N}$ ocorrido na planta nos últimos ciclos não foi na forma de proteína verdadeira de lenta degradação.

A parte da proteína ligada à parede celular, nFDN e nFDA, que representa também, as frações B3 e C para Cornell, podem ser vistas nas Figuras 11 e 12. A fração nFDN foi a variável mais estável ao longo do ano, pois não apresentou nenhuma diferença entre os ciclos de pastejo, representando em média, 49,11\% PB.

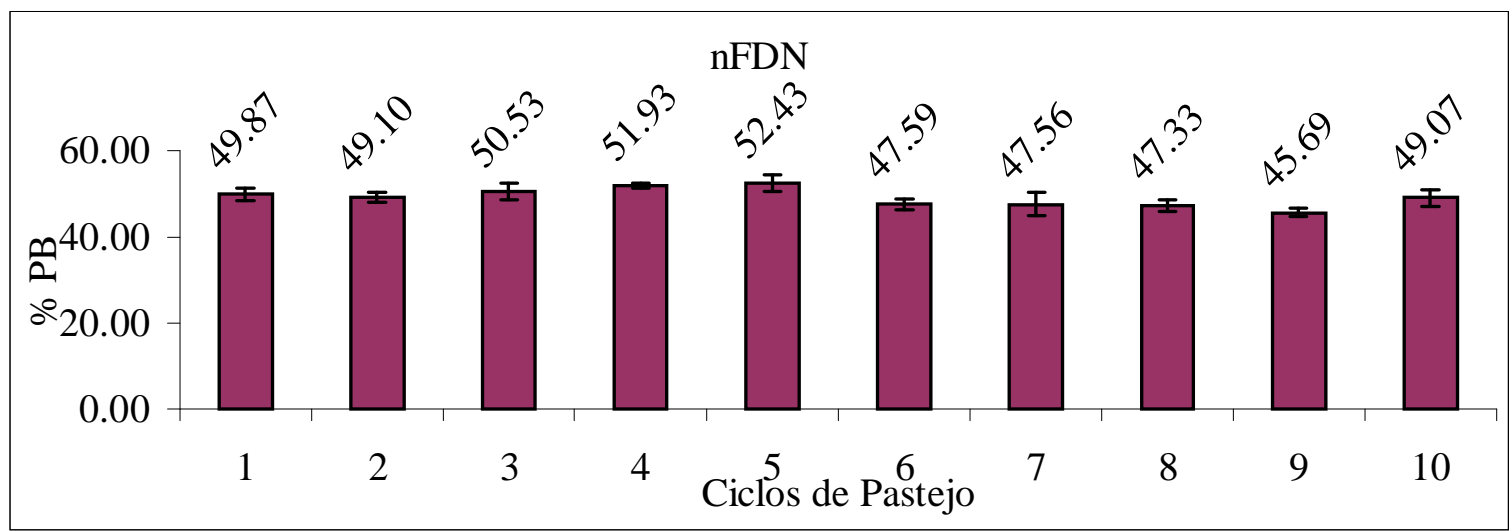

Figura 11- Teor de nFDN em \% do nitrogênio total de amostras de pastejo simulado de capim Tanzânia (Panicum maximum Jacq.), médias de três níveis de resíduo pós-pastejo (Baixo, Médio e Alto) ao longo de 10 ciclos de pastejos. Barras indicam o erro padrão da média.

O nFDA apresentou maior variação, os valores estiveram entre 6,48 e 11,94\% PB. Do mesmo modo que para a fração B1, pode-se dizer que o acúmulo de $\mathrm{N}$ na planta não se deu na forma de proteína aderida a parede, pois para os maiores valores de PB houve menores proporções de nFDA. Assim, as menores proporções de nFDA foram para os últimos pastejos.

A fração B3 representa a proteína de maior proporção na planta, é a subtração do $\mathrm{nFDN}$ pelo nFDA, e seria a proteína aderida à parede celular com potencial para ser degradada, no entanto, com baixa taxa de degradação. Em média, a fração B3 foi de $40 \%$ PB (Figura 13). 


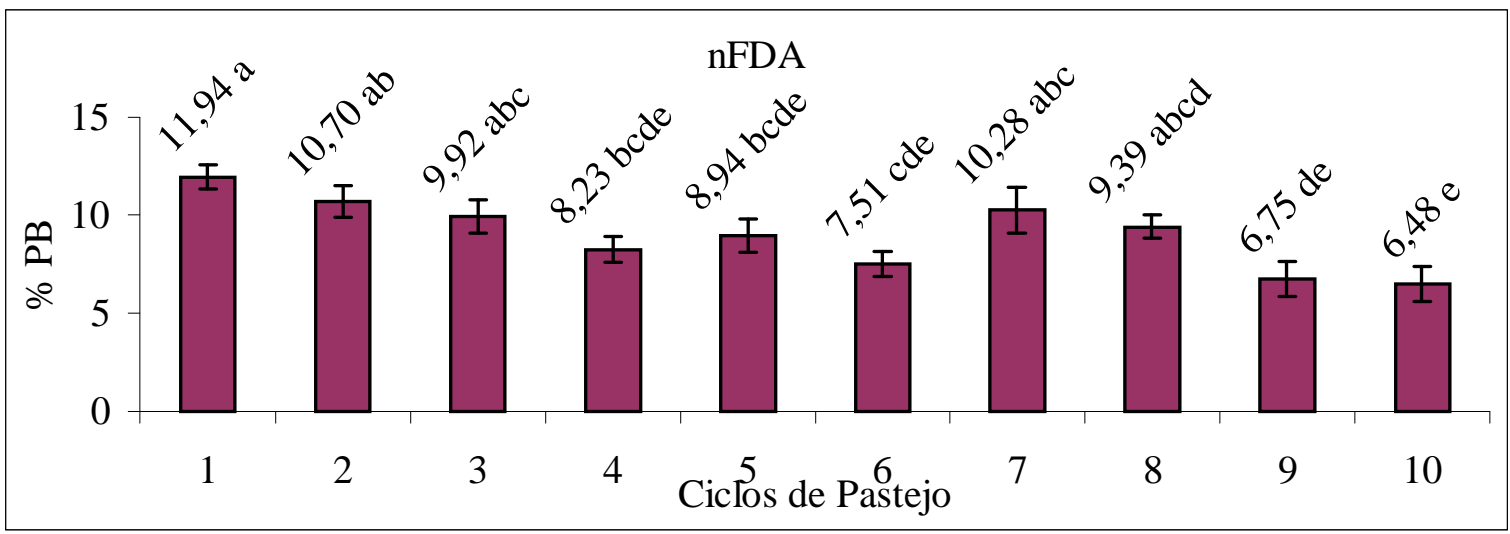

Figura 12- Teor de nFDA em \% do nitrogênio total de amostras de pastejo simulado de capim Tanzânia (Panicum maximum Jacq.), médias de três níveis de resíduo pós-pastejo (Baixo, Médio e Alto) ao longo de 10 ciclos de pastejos. Médias seguidas da mesma letra não diferem significativamente pelo teste de Tukey $(\mathrm{P}>0,05)$. Barras indicam o erro padrão da média.

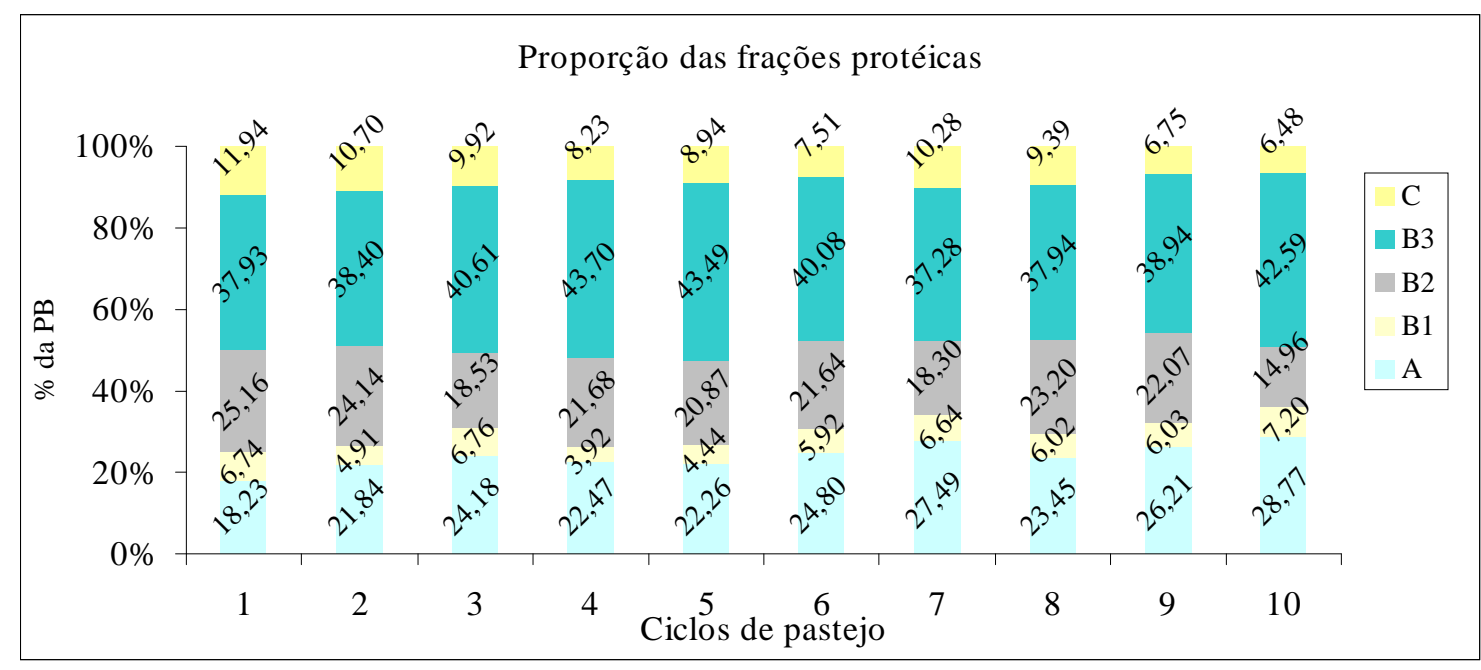

Figura 13- Proporção das frações protéicas em \% da proteína de amostras de pastejo simulado de capim Tanzânia (Panicum maximum Jacq.), médias de três níveis de resíduo pós-pastejo (Baixo, Médio e Alto) ao longo de 10 ciclos de pastejos.

Os teores de matéria mineral variaram entre 7,87 e 10,47\% MS. Esses valores seguem as tendências de altos teores, comuns em pastagens tropicais adubadas. Apesar 
de haver diferença no teor de MS para o ciclo de pastejo 10 em relação a outros pastejos, nenhum motivo pôde ser apontado para se justificar o fato (Figura 14).

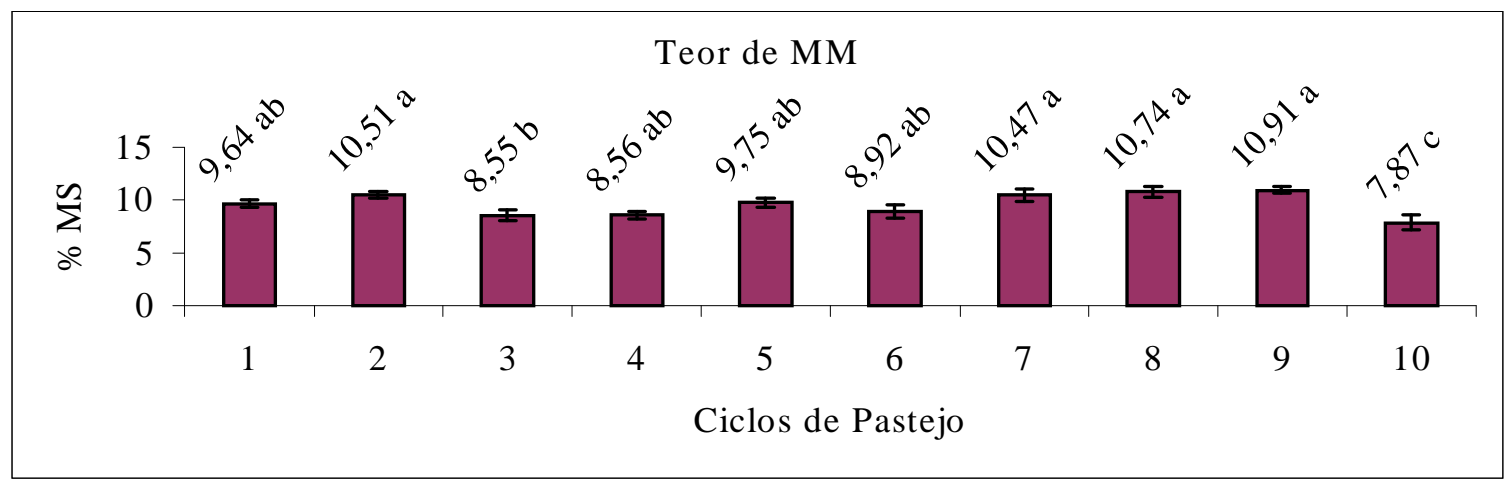

Figura 14- Teor de matéria mineral em \% da matéria seca de amostras de pastejo simulado de capim Tanzânia (Panicum maximum Jacq.), médias de três níveis de resíduo pós-pastejo (Baixo, Médio e Alto) ao longo de 10 ciclos de pastejos. Médias seguidas da mesma letra não diferem significativamente pelo teste de Tukey $(\mathrm{P}>0,05)$. Barras indicam o erro padrão da média.

A alta proporção de proteína solúvel (fração A) promoverá grandes perdas de nitrogênio via amônia, essa pode ser reciclada para o rúmen, no entanto, uma grande parte deve ser metabolizada e retirada do organismo. Esse processo gasta energia e é chamada de custo uréia (Owens \& Zinn, 1988).

A uréia pode ser reciclada para o rúmen por duas vias: saliva ou parede ruminal. Essa última, graças à urease produzida por microorganismos, pois o tecido animal não produz urease. Quanto menor o teor de PB na dieta, maior a reciclagem de $\mathrm{N}$ na forma de uréia vinda do fígado para o rúmen. Owens \& Zinn (1988) citam que, em dietas contendo de 5 à $20 \% \mathrm{~PB}$, a reciclagem foi respectivamente de 70 a $11 \%$ do nitrogênio consumido. De 23 à $92 \%$ da uréia pode ser reciclada para o rúmen.

$\mathrm{Na}$ avaliação do teor de proteína das plantas relacionado à exigência animal deve-se levar em consideração não só a categoria animal, mas também a raça, pois, sabese que os zebuínos apresentam maior capacidade de reciclagem de uréia para o rúmen 
que os taurinos. Isso significa que os zebuínos podem apresentar desempenhos semelhantes em condições de menor disponibilidade de proteína degradável no rúmen, e que os taurinos respondem melhor à suplementação protéica que os próprios zebuínos.

A fração B3, como possui lenta taxa de degradação, dependendo da taxa de passagem da fase sólida pelo rúmen, apresentará baixas degradações (Cap. 4). Desse modo, as frações que representam cerca de $70 \%$ da proteína do capim Tanzânia (A, B3 e C) possuem problemas de utilização pelos ruminantes. Isso significa que, apesar dos altos teores de proteína nessas pastagens, poderá, em algum momento após o consumo da forragem pelos animais, haver déficit ruminal de proteína.

Por outro lado, o efeito negativo da lignina, observado pelos altos teores da fração C dos carboidratos, reduz significativamente a disponibilidade de energia das plantas tropicais para o ruminante. Entretanto, deve-se levar em consideração os bons teores da fração A + B1 dos carboidratos (em torno de 20\% CT), mesmo não tendo valores adequados em relação à fração A da proteína (apresentam taxas de degradação semelhantes) que possam levar a um bom aproveitamento de boa parte dessa fração protéica.

De forma geral, existem variações na qualidade da forragem ao longo do ano, tanto da parte protéica como dos carboidratos. No entanto, deve-se ressaltar que a qualidade da planta em áreas irrigadas apresenta-se com menores alterações que em pastagens de sequeiro. Apesar disso, a pequena variação na qualidade nutricional das plantas proporciona grandes alterações quando se avalia a relação da proteína degradável com a energia disponível no rúmen (Cap. 4). Desse modo, sistemas em pastagens de Tanzânia irrigados, quando utilizarem suplementações concentradas devem levar em consideração a qualidade nutricional das plantas, sendo que o tipo de concentrado deverá ser alterado dependendo da qualidade da forragem ao longo do ano.

O fato de não haver diferenças significativas da qualidade da planta nos três tratamentos, indica que o desempenho animal poderá estar associado a algumas características físicas da planta que interfiram diretamente no consumo de matéria seca, somente isso poderia explicar ganhos de peso menores no tratamento de menor resíduo pós-pastejo (T1), como definido por Penati ${ }^{4}$. 


\subsection{Conclusões}

Não houve diferenças entre os tratamentos ao longo dos ciclos de pastejos para nenhum dos parâmetros nutricionais avaliados.

As menores qualidades, evidenciadas pelos menores teores de NDT e fração C dos carboidratos, foram verificadas nos ciclos de pastejos correspondentes aos meses de julho a setembro.

A menor qualidade nos meses de julho a setembro pode estar relacionado a menor renovação de tecidos durante o período de inverno e a um provável acúmulo de perfilhos florescidos desde o mês de abril.

Os teores de proteína podem ser considerados altos e tiveram tendência de aumento com o avanço dos ciclos de pastejos, isso pode ser justificado pelas adubações nitrogenadas nos pastejos de inverno, o que promoveu consumo de luxo de $\mathrm{N}$, havendo acumulo, principalmente na forma de $\mathrm{NnP}$.

A maior proporção do $\mathrm{N}$ se encontra na parede celular, aproximadamente $50 \%$, indicando que essa fração deve ser prioridade de estudos no tocante a cinética de degradação ruminal, para uma melhor caracterização da proteína das plantas de Tanzânia. 


\section{CINÉTICA DA DEGRADAÇÃO RUMINAL DE AMOSTRAS DE PASTEJO SIMULADO DE CAPIM TANZÂNIA, PASTEJADO SOB TRÊS NÍVEIS DE RESÍDUO PÓS-PASTEJO, COLHIDAS NAS ESTAÇÕES DE VERÃO, OUTONO E PRIMAVERA.}

\section{Resumo}

O uso do programa de Cornell indica a necessidade de estudos sobre a degradação dos diferentes componentes da MS. O objetivo deste trabalho foi o de avaliar a cinética ruminal da MS e das frações FDN, PB e nFDN de amostras de pastejo simulado de capim Tanzânia (Panicum maximum Jacq.), coletadas em três épocas do ano (verão, outono e primavera), em pastagens irrigadas submetidas a três níveis de resíduo pós-pastejo $(\mathrm{T} 1=1267 \mathrm{~kg}$ matéria seca verde $/ \mathrm{ha} ; \mathrm{T} 2=2914 \mathrm{~kg}$ matéria seca verde/ha; T3= $4256 \mathrm{~kg}$ matéria seca verde/ha). Para cada período de incubação foram usados 3 animais com fístula de rúmen. Os tempos de incubação foram: 0, 3, 6, 9, 12, 24, 30, 48, 60, 72, 96 horas. No resíduo do material incubado foi determinado FDN, PB e nFDN utilizando-se do NIRS. O T1 foi o tratamento que apresentou maior redução de digestibilidade entre o verão $(81,41 \%)$ e a primavera $(74,96 \%)$. A fração prontamente solúvel da proteína pode ser maior que $40 \%$ da PDR, que variou entre 76,36 e 62,05\% da PB. A fração indigestível da FDN (C) é maior que a estimada pelo CNCPS a partir dos teores de lignina/FDN multiplicados por 2,4. Os resultados deste trabalho indicam que o fator de multiplicação deve estar entre 2,91 e 3,35. A fração C do nFDN (12,11 a $17,08 \%)$ é maior que a calculada em laboratório como sendo nFDA (6,48 a 10,7\%). Quanto maior o teor de PB e de nFDN, pior foi a digestibilidade da PB. 


\section{Summary}

The objective of this work was to study DM, NDF, CP and nNDF ruminal kinectics of irrigated Tanzania grass (Panicum maximum Jacq.). Simulated-grazed samples were collected on three periods of the year (spring, summer and fall) on irrigated paddocks, rotationally grazed to three post grazing green dry matter residues ( $\mathrm{T} 1=$ low, $\mathrm{T} 2=$ medium and $\mathrm{T} 3=$ high). Three rumen cannulated animals were used in a 3 x 3 Latin square design to determine the in situ degradability up to 96 hours of incubation. $\mathrm{NDF}, \mathrm{CP}$ and $\mathrm{nNDF}$ were determined through NIRS in the residue remaining in the bags. Forage quality was the highest in the summer. The low post grazing residue treatment showed the largest increase in digestibility in all fractions from spring $(74.96 \%)$ to summer $(81.41 \%)$. The soluble protein fraction showed values up to $40 \%$ of the RDP, which varied from 62 to $76 \%$ of the CP. The NDF C fraction was underestimated by the CNCPS; our data suggests the \%lignin/\% NDF should be multiplied by a factor between 2.91 and 3.35. The CNCPS overestimated the nNDF C fraction (12.11 to $17.08 \%$ ) as compared to the wet lab analysis value, as regarded to be the nADF fraction (6.48 to 10.7\%). In general our results showed that the CP digestibility decreased as the $\mathrm{CP}$ and nNDF contents increased.

\subsection{Introdução}

Na busca por uma sincronização da degradação ruminal entre carboidratos e proteína, faz-se necessário elucidar as taxas de degradação da matéria seca e das diferentes frações que compõem os carboidratos e as proteínas. Com o surgimento e evolução do programa de Cornell (Sniffen et al., 1992; Russel et al., 1992; Fox et al., 1992), uma nova forma de se prever o desempenho de bovinos foi adotada. Até então, os programas de predição de desempenho eram estáticos, não levando em consideração os vários componentes do alimento com suas diferentes taxas de degradação ruminal e suas interações. O programa de Cornell tenta ser um sistema dinâmico, adotando taxas de 
passagem e taxas de degradação diferenciadas para cada fração da proteína e dos carboidratos.

Principalmente devido ao florescimento, os teores de proteína, lipídios, minerais e carboidratos solúveis tendem a se reduzir, enquanto que a parede celular e seus componentes passam a ter maior proporção da matéria seca. Com o florescimento ocorre também o aumento do teor de lignina e a lignificação da parede celular.

A digestibilidade da parede celular é influenciada tanto pelo teor como pelas características físicas dos polissacarídeos da parede, como o grau de cristalinidade e polimerização (Fritz et al., 1990).

A hemicelulose é a fração mais afetada pela lignificação. Apesar dessa fração apresentar maior potencial de digestibilidade que outros componentes da parede celular, essa não tem sua degradação maximizada, pois se concentra, principalmente, na parede primária. Como a degradação da célula inicia-se pelo seu interior seguindo para a parede secundária, quando o microorganismo atinge a parede primária, que é a porção externa da célula, a partícula já está deixando o rúmen. Desse modo, plantas forrageiras de maior idade fisiológica, ou florescidas, apresentam maior redução na digestibilidade da hemicelulose que da celulose (Messman et al., 1991).

Assim, o aumento no teor de lignina afeta diretamente a fração degradável da FDN (Caballero et al., 2001). Como o teor de lignina aumenta em proporção maior que o teor de FDN com o avanço da idade da planta, a degradação da matéria seca tem correlação maior com a digestibilidade da FDN que com o teor dessa fração (Deschamps, 1999).

Vieira et al. (2000b) avaliaram as taxas de degradação das frações carboidrato de amostras de extrusa em pastagens nativas coletadas em duas épocas do ano: águas e seca. A fração dos carboidratos estruturais disponível dessas amostras apresentou taxas de degradação de $9,00 \% / \mathrm{h}$ no período das águas e de $6,20 \% / \mathrm{h}$ no período de seca. Enquanto, a degradação efetiva (DE) dessas amostras foi de 73,50 e 68,50\% para águas e seca, respectivamente.

Ribeiro et al. (2001) avaliaram a cinética ruminal em amostras de feno de Tifton- 85 colhido em diferentes idades de rebrota $(28,35,42$ e 56 dias). A taxa de degradação dos carboidratos estruturais disponíveis variou de 4,00 a 4,66 \%/h, sendo os menores valores para plantas de maior idade fisiológica. 
O programa de Cornell, em sua última versão, apresenta um banco de dados para plantas tropicais. Para essas plantas, a taxa de degradação da porção da parede celular disponível, em média, é de 4,86 \%/h. Plantas de Capim Guine (Panicum maximum) são apresentadas com taxas de degradação para essa fração da parede celular na ordem de $7 \% / \mathrm{h}$. No entanto, o banco de dados de Cornell apresenta grande variação para as taxas de degradação da parede celular de plantas tropicais $(3$ a 8,10 \%/h).

Malafaia et al. (1997) caracterizaram as frações nitrogenadas e avaliaram a cinética ruminal dessas frações em algumas gramíneas tropicais. Em plantas de Tifton85, Capim-elefante, Brachiaria brizantha e Brachiaria decumbens, encontraram para a fração B3 (proteína potencialmente degradável aderida à parede celular) taxas de degradação de 0,$15 ; 0,06 ; 0,25 ; 0,95 \% / h$. Essas taxas de degradação das frações protéicas foram determinadas através da utilização de proteases extraídas do líquido ruminal. Para Plantas de Tifton-85 e Capim-elefante, o NRC (1996) indica 0,09 \%/h como taxa de degradação da fração B3.

Ribeiro et al. (2001) avaliaram a taxa de degradação da fração B3 da proteína de amostras de feno de Tifton-85 colhido em diferentes idades de rebrota $(28,35,42$ e 56 dias). A taxa de degradação variou de 0,77 a 1,20 \%/h, sendo que houve tendência de serem menores em idades avançadas da planta.

Vieira et al. (2000a) trabalharam com o fracionamento de amostras da extrusa de animais em pastagens naturais da Zona da Mata, MG. Essas amostras foram coletadas quatro vezes em duas épocas do ano, chuvas e seca. As determinações das taxas de degradação e da degradação potencial da fração B3 da proteína foi obtida in vitro com proteases originadas do Streptomyces griseus. A taxa de degradação variou entre 3,2 a $8,0 \% / \mathrm{h}$. Os maiores valores encontrados foram para início da estação das chuvas, assim como, para a degradação potencial dessa fração protéica $(59,50$ a 79,60 \%).

As taxas de degradações da proteína encontradas por Vieira et al. (2000a) apontam para valores bem maiores que os indicados por Malafaia et al. (1997) e Ribeiro et al. (2001). Vieira et al. (2000a) justificam essas diferenças de duas formas: devido ao tratamento matemático aplicado aos diferentes intervalos de linearidade para degradação de cada fração (Vieira et al., 1997), e também por serem suas análises originadas de amostras de extrusa, o que pressupõe serem de melhor qualidade quando comparadas com amostras simulando o pastejo. 
O programa de Cornell trás para taxa de degradação da fração B3 da proteína de plantas tropicais valores variando de 0,09 a 10,50\%/h, em média, a taxa de degradação foi de $2,38 \% / \mathrm{h}$. Para plantas de Guiné (Panicum maximum), a taxa de degradação de B3 foi de 6,60 a 10,50 \%/h.

Em pastagens tropicais, as frações protéicas de rápida degradação $(\mathrm{NnP}$ e Nsol) representam grande proporção da proteína. A não ser em algumas exceções (Lima et al., 1999), a soma dessas frações é superior a $20 \%$ do total da proteína. Somando-se a esse total a fração protéica de degradação média, encontram-se teores acima de $50 \%$ da PB (Malafaia et al., 1997; Vieira et al., 2000a; Lanna et al., 1996). A rápida taxa de degradação dessas frações no rúmen pode promover o aumento da concentração de amônia no meio, fazendo com que haja aumento de perda de nitrogênio.

$\mathrm{O}$ aumento de perda de nitrogênio, em pastagens tropicais, logo após os picos de consumo, pode ser justificado também pela falta de carboidratos de rápida degradação ruminal, carboidratos solúveis, amido e pectina (Vieira, et al., 2000b).

Por outra lado, a fração protéica de lenta degradação, a B3, representa a maior proporção da proteína a atingir o intestino delgado. No entanto, juntamente com a fração $\mathrm{C}$, representa também a maior parte das proteínas ingeridas que são excretadas nas fezes. Assim, o fornecimento de uma proteína de degradação intermediária, supriria uma eventual deficiência momentânea de proteína ruminal, fazendo com que se tenha maior sincronização da proteína com a MOD no rúmen, o que pode promover maior síntese microbiana.

O uso da metodologia do infravermelho proximal (Nirs) viabiliza o estudo detalhado das degradações das frações da parede celular (FDN, FDA, celulose e hemicelulose), assim como das frações nitrogenadas (nFDN, nFDA, NnP, Nsol). Com a análise líquida (convencional) de alguns tempos de degradação para cada fração da planta, pode-se estimar com certa segurança os valores dessas determinações para todos os tempos e com isso, se fazer o cálculo das degradações e taxas de degradações (Cozollino et al., 2001; Berzaghi, et al., 1997).

O objetivo desse trabalho foi avaliar a cinética ruminal de amostras de pastejo simulado de capim Tanzânia coletadas em três épocas do ano (verão, outono e primavera) em pastagens irrigadas submetidas a três resíduo pós-pastejo (Baixo, Médio e Alto). 


\subsection{Material e Métodos}

O experimento foi conduzido na Fazenda Areão da Escola Superior de Agricultura "Luiz de Queiroz" da Universidade de São Paulo, em Piracicaba, São Paulo ( $22^{0} 42^{\prime} 30^{\prime \prime}$ lat. S; 47 38'00" long. W; 546 m altitude). A forragem utilizada foi o capim Tanzânia (Panicum maximum Jacq.) estabelecido em área irrigada através de pivô central. A pastagem foi manejada através de pastejo rotacionado com 33 dias de descanso e três dias de ocupação. Os tratamentos, com quatro repetições, foram constituídos de três níveis de resíduo pós-pastejo, a saber: T1 - Baixo, T2 - Médio e T3 - Alto, os valores de resíduo pós-pastejo correspondentes aos períodos de avaliação da cinética ruminal constam da Tabela 1. Para cada tratamento havia 12 parcelas de 1330 $\mathrm{m}^{2}$ distribuídos em quatro blocos. Cada parcela era subdividida em três piquetes para facilitar o manejo.

Tabela 1. Resíduo pós-pastejo em $\mathrm{kg}$ de MS verde/ha em quatro épocas do ano para três níveis de resíduo (T1- Baixo, T2- Médio e T3- Alto) para o capim Tanzânia (Panicum maximum Jacq.) irrigado.

\begin{tabular}{lllll}
\hline Tratamento & Época 1 & \multicolumn{1}{c}{ Época 2 } & Época 3 & Época 4 \\
\hline & & \multicolumn{2}{c}{$\mathrm{kg} \mathrm{MSV/ha}$} \\
$\mathrm{T} 1$ & $1277^{\mathrm{Aab}}$ & $1763^{\mathrm{Aab}}$ & $816^{\mathrm{Ab}}$ & $1210^{\mathrm{Aba}}$ \\
$\mathrm{T} 2$ & $2459^{\mathrm{Ba}}$ & $3346^{\mathrm{Bb}}$ & $2548^{\mathrm{Bab}}$ & $3306^{\mathrm{Bb}}$ \\
$\mathrm{T} 3$ & $3106^{\mathrm{Ca}}$ & $5335^{\mathrm{Cb}}$ & $3113^{\mathrm{Ca}}$ & $5471^{\mathrm{Cb}}$ \\
\hline
\end{tabular}

Época 1 - 29/10/1999 a 14/02/2000

Época 2 - 15/02/2000 a 02/06/2000

Época 3 - 03/06/2000 a 13/08/2000

Época 4 - 18/09/2000 a 29/11/2000

Médias seguidas da mesma letra minúsculo na coluna ou maiúscula na linha não diferem significativamente $(\mathrm{P}>0,05)$. 
O solo foi corrigido para garantir os seguintes níveis de fertilidade: saturação por bases, $80 \%$; fósforo, $30 \mathrm{mg} / \mathrm{dm}^{3}$; potássio, $5 \%$ da CTC. Imediatamente após cada pastejo os piquetes eram adubados com $80 \mathrm{~kg} / \mathrm{ha}$ de $\mathrm{N}$ e $80 \mathrm{~kg} / \mathrm{ha}$ de $\mathrm{K}_{2} \mathrm{O}$ em todos os ciclos ao longo de 1 ano.

A pastagem foi formada em abril de 1999, o primeiro pastejo foi em agosto de 1999, após esse, mais dois pastejos se sucederam, os quais foram chamados de pastejo de estabelecimento dos tratamentos.

Foram coletadas amostras simulando o pastejo em três épocas distintas do ano: verão, outono e primavera. As amostras coletadas nos meses de dezembro e janeiro, foram correspondentes à estação de verão, as amostras de abril corresponderam às amostras de outono e as de outubro às de primavera.

As amostras coletadas em dezembro/janeiro, foram incubadas em fevereiro, as colhidas em abril foram incubadas em maio e as de outubro foram incubadas em novembro/dezembro.

Para cada um dos três períodos de incubação foram usados 3 animais com fístula de rúmen. $\mathrm{O}$ delineamento experimental para degradação ruminal foi um quadrado latino 3 x 3 (três animais em três períodos) para cada uma das épocas do ano.

A degradabilidade foi estudada nos seguintes tempos de incubação: 0, 3, 6, 9, 12, 24, 30, 48, 60, 72, 96 horas. Entre um período e outro do quadrado latino os animais mudavam de tratamento, um tempo de 14 dias, como adaptação, era esperado para a incubação do material daquele tratamento.

A metodologia utilizada para a degradação ruminal foi a de Nocek (1988):

- tamanho da partícula do material incubado: $5 \mathrm{~mm}$

- material dos sacos: Náilon com porosidade de 50 micras

- tamanho dos sacos: 7 x $14 \mathrm{~cm}$

- quantidade de material por saco: até 6 gramas

- repetições: 3 sacos por tempo

- lavagem dos sacos: lavagem após retirada dos sacos do rúmen em água corrente até o momento em que a água se tornasse límpida. 
- colocação dos sacos no rúmen: colocação segundo os tempos de incubação e retirada de uma só vez.

A degradabilidade potencial (DP) e a degradabilidade efetiva (DE) da MS, FDN, FDA, PB e nFDN foram calculadas utilizando-se o modelo matemático proposto por Mehrez \& Orskov (1977) e descrito por Grant \& Mertens (1992):

Degradação potencial:

$\mathrm{DP}=\mathrm{A}+\mathrm{B}(1-\mathrm{e}-\mathrm{c}(\mathrm{t}-\mathrm{T}))$, onde:

$\mathrm{DP}=$ degradabilidade potencial para o tempo $\mathrm{t}(\%)$;

$\mathrm{A}=$ fração solúvel (\% do original);

$\mathrm{B}=$ fração potencialmente degradável (\% do original);

$\mathrm{c}=$ taxa de degradação da fração B $(\% / \mathrm{h})$;

$\mathrm{t}=$ tempo de incubação $(\mathrm{h})$

$\mathrm{T}=$ Tempo de colonização (Lag time).

Degradação efetiva:

$\mathrm{DE}=\mathrm{A}+\left(\left(\mathrm{B} \times \mathrm{c}\left(-\mathrm{k}^{*} \mathrm{~T}\right)\right) /(\mathrm{c}+\mathrm{k})\right.$, onde:

$\mathrm{DE}=$ Degradação efetiva $(\%)$

$\mathrm{k}=$ taxa de passagem da fase sólida

$\mathrm{c}=$ taxa de degradação da fração B $(\% / \mathrm{h})$

$\mathrm{T}=$ tempo de colonização (Lag time)

$\mathrm{A}=$ fração solúvel ( $\%$ do original);

$\mathrm{B}=$ fração potencialmente degradável (\% do original);

Para a degradação efetiva, foi feito o cálculo com duas taxas de passagem, 2 e 3,5 \%/h, representando uma categoria animal de menor e outra de maior consumo de MS, respectivamente.

A fração "A" foi obtida pela lavagem do material que não foi colocado no rúmen (tempo zero); a fração "B", por $(100$ - $(\mathrm{A}+\mathrm{C}))$; "CC" é a fração indigestível, calculada como sendo o resíduo do último tempo de incubação, expresso em \%. 
A taxa de degradação ("c"), foi calculada através da regressão do logaritmo natural (ln) do resíduo potencialmente degradável (B) entre o tempo de incubação logo após o lag time e o tempo de incubação de estabilização da degradação. O lag time é o tempo até o início da degradação da fração B.

O lag time foi calculado segundo o modelo proposto por McDonald (1981): (ln RPD t0 - $\ln$ RPD t)/c, em que:

ln RPD t0 = logaritmo natural do resíduo potencialmente degradável no tempo 0 hora;

$\ln$ RDP $\mathrm{t}=$ logaritmo natural do resíduo potencialmente degradável no último tempo utilizado de incubação;

$\mathrm{c}=$ taxa de degradação da fração $\mathrm{B}(\% / \mathrm{h})$.

As determinações da FDN, FDA, PB e nFDN no resíduo do material incubado foram realizadas através de espectroscopia de reflectância de infravermelho proximal (NIRS) (Berzaghi et al., 1997; Cozzolino et al., 2001). O equipamento utilizado foi um monocromato NIRS 5000 (NIRSystems, Silver Spring, MD, USA).

Um conjunto de 1188 amostras foi escaneado no equipamento que lê comprimentos de onda entre 700 e $2100 \mathrm{~nm}$. Esses espectros foram estocados em curva $\log (1 / \mathrm{R})$ em intervalos de $2 \mathrm{~nm}$. Utilizando-se os métodos de seleção de amostras existentes no software do equipamento, foram descartadas amostras distantes mais de 3 H (distância padronizada de Mahalanobis) da média, essas foram tidas com “outliers”.

Adotou-se uma distância mínima de 0,6 H entre amostras para a seleção daquelas em que seriam efetuadas as análises bromatológicas convencionais (Shenk \& Westerhaus, 1991). O total de amostras selecionadas para análise convencional foi de 250.

Após as amostras selecionadas terem sido analisadas para FDN, FDA, PB e nFDN, utilizou-se os métodos estatísticos existentes no software do NIRS para o desenvolvimento das equações de determinação para cada fração. Assim, com as equações desenvolvidas foi possível a estimativa das outras 938 amostras que não haviam sido determinadas por análises químicas. 
A composição nutricional da forragem para as diferentes estações do ano consta da Tabela 2. Como não houve diferenças entre os tratamentos, os valores expressam a médias dos três tratamentos em cada ciclo de amostragem de forragem.

Tabela 2. Composição nutricional de amostras do pastejo simulado de capim Tanzânia (Panicum maximum Jacq.) irrigado pastejado sob três níveis de resíduo póspastejo (T1- Baixo, T2- Médio e T3- Alto) e em três estações do ano (verão, outono e primavera).

\begin{tabular}{lccc}
\hline & Verão & Outono & Primavera \\
\hline & Componentes da parede celular & \\
FDN \% MS & 66,15 & 65,60 & 64,52 \\
FDA \% MS & 33,18 & 34,31 & 34,63 \\
Lignina \% MS & $3,34^{\mathrm{b}}$ & $3,87^{\mathrm{a}}$ & $3,85^{\mathrm{a}}$ \\
Fração B2 \% CT & $70,35^{\mathrm{a}}$ & $67,53^{\mathrm{ab}}$ & $65,14^{\mathrm{b}}$ \\
Fração C \% CT & 16,00 & 18,43 & 18,96 \\
& Componentes protéicos & \\
PB \% MS & $11,77^{\mathrm{b}}$ & $11,41^{\mathrm{b}}$ & $14,61^{\mathrm{a}}$ \\
Nsol \% PB & $26,75^{\mathrm{b}}$ & $26,70^{\mathrm{b}}$ & $35,97^{\mathrm{a}}$ \\
NnP \% PB & $21,84^{\mathrm{b}}$ & $22,26^{\mathrm{ab}}$ & $28,77^{\mathrm{a}}$ \\
nFDN \% PB & 49,10 & 52,43 & 49,07 \\
nFDA \% PB & $10,70^{\mathrm{a}}$ & $8,94^{\mathrm{b}}$ & $6,48^{\mathrm{b}}$ \\
Fração B2 \% PB & $24,14^{\mathrm{a}}$ & $20,87^{\mathrm{a}}$ & $14,96^{\mathrm{b}}$ \\
& & & \\
NDT \% MS & 57,49 & 57,28 & 59,31 \\
MM \% MS & $10,51^{\mathrm{a}}$ & $9,75^{\mathrm{a}}$ & $7,87^{\mathrm{b}}$ \\
\hline
\end{tabular}

Médias seguidas da mesma letra na linha não diferem significativamente pelo teste de Tukey $(\mathrm{P}>0,05)$.

\section{Análise estatística}

A análise estatística foi feita considerando um delineamento em quadrado latino 3 x 3 com sub-amostras, constituído por 3 períodos, 3 animais, 3 tratamentos e 4 sub-amostras por tratamento. Este delineamento foi repetido em três épocas do ano.

Inicialmente foi realizada uma análise por separado para cada época do ano. Diferenças significativas entre tratamentos foram testadas através do teste de Tukey no 
nível de significância de 5\%. Posteriormente, procedeu-se uma análise conjunta incluindo as três épocas do ano, seguindo a metodologia de Brien (2001) para o caso de quadrados latinos repetidos na mesma área em diferentes intervalos de tempo. Este delineamento permite testar o efeito da época do ano e a interação entre épocas e as duas fontes de variação do quadrado latino (período e animais) por separado, mas não permite testar a interação época do ano e tratamento.

As análises forma feitas usando o programa Genstat 5.0 (Genstat, 1999).

Posteriormente foram realizadas correlações simples e múltiplas entre as degradações efetivas das frações e com alguns parâmetros nuticionais da planta. Os procedimentos usados forma o PROC CORR e PROC CANCORR do SAS (SAS, 1990)

\subsection{Resultados e Discussão}

A Tabela 3 apresenta as frações da MS consideradas prontamente solúvel (A), potencialmente degradável (B) e indigestível (C). Não houve diferenças significativas para a fração A entre os tratamentos para as três época do ano. A comparação das médias dos tratamentos em cada época do ano indica menor fração solúvel para o período de verão em relação aos períodos de outono e primavera (16,70; 21,22 e 19,34 \% MS, respectivamente para verão, outono e primavera).

A fração potencialmente degradável B não apresenta diferenças significativas para os três tratamentos nas três épocas do ano. Para o período de verão a fração B representou 63,32\% MS, que foi maior que quando comparados aos teores de outono $(54,52 \% \mathrm{MS})$ e de primavera $(55,70 \% \mathrm{MS})$. A soma das frações A e B foram maiores para o T1 no período de verão, enquanto que para as demais épocas do ano não houve diferenças.

No verão, a fração indigestível (C) foi menor para o T1 (18,23 \%MS), comparado aos teores dessa fração para o T2 e T3, nas demais estações do ano não houve diferença entre os tratamentos para essa fração. Em média, no verão a fração $\mathrm{C}$ foi 
menor (19,98 \%MS), comparado às demais épocas do ano, o que mostra uma redução na qualidade da planta do verão para o outono e primavera.

Tabela 3. Frações $\mathrm{A}, \mathrm{B}, \mathrm{A}+\mathrm{B}$ e $\mathrm{C}$ da matéria seca incubada no rúmen de amostras de pastejo simulado de capim Tanzânia (Panicum maximum Jacq.) irrigado coletadas em três épocas do ano (verão, outono e primavera) para três resíduos póspastejo (T1- Baixo; T2- Médio e T3- Alto).

\begin{tabular}{lcccc}
\hline Época do ano & T1 & T2 & T3 & Média \\
\hline Verão & $16,76 \pm 1,82$ & $15,47 \pm 1,76$ & $17,86 \pm 0,90$ & $16,70^{\mathrm{B}}$ \\
Outono & $21,91 \pm 0,55$ & $20,94 \pm 1,13$ & $20,80 \pm 0,84$ & $21,22^{\mathrm{A}}$ \\
Primavera & $17,29 \pm 2,13$ & $19,52 \pm 1,97$ & $21,22 \pm 0,90$ & $19,34^{\mathrm{A}}$ \\
& \multicolumn{4}{c}{ Fração B } \\
Verão & $65,00 \pm 2,02$ & $63,60 \pm 1,53$ & $61,36 \pm 1,13$ & $63,32^{\mathrm{A}}$ \\
Outono & $54,65 \pm 1,04$ & $54,44 \pm 1,48$ & $54,48 \pm 0,92$ & $54,52^{\mathrm{B}}$ \\
Primavera & $58,70 \pm 2,43$ & $55,40 \pm 2,06$ & $52,80 \pm 1,52$ & $55,70^{\mathrm{B}}$ \\
& & Fração A $+\mathrm{B}$ & & \\
Verão & $81,77^{\mathrm{a}} \pm 0,56$ & $79,06^{\mathrm{b}} \pm 0,58$ & $79,23^{\mathrm{b}} \pm 0,86$ & $80,02^{\mathrm{A}}$ \\
Outono & $76,56 \pm 1,28$ & $75,38 \pm 1,11$ & $75,28 \pm 1,11$ & $75,74^{\mathrm{B}}$ \\
Primavera & $76,03 \pm 1,01$ & $74,96 \pm 0,71$ & $74,06 \pm 1,69$ & $75,02^{\mathrm{B}}$ \\
& & Fração C & \\
Verão & $18,23^{\mathrm{b}} \pm 0,56$ & $20,94^{\mathrm{a}} \pm 0,58$ & $20,77^{\mathrm{a}} \pm 0,86$ & $19,98^{\mathrm{B}}$ \\
Outono & $23,44 \pm 1,28$ & $24,62 \pm 1,11$ & $24,72 \pm 1,11$ & $24,26^{\mathrm{A}}$ \\
Primavera & $23,97 \pm 1,01$ & $25,04 \pm 0,71$ & $25,94 \pm 1,69$ & $24,98^{\mathrm{A}}$ \\
\hline
\end{tabular}

Médias seguidas da mesma letra minúscula na linha ou maiúscula na coluna não diferem significativamente pelo teste de Tukey $(\mathrm{P}>0,05)$.

Seguindo a tendência de queda de qualidade do capim Tanzânia da estação de verão para o outono e primavera, verifica-se na Tabela 4 maiores taxas de degradação da MS para o verão, maior degradação potencial (DP\%) e maior degradação efetiva, quando se considerou a taxa de passagem de $2 \% / \mathrm{h}$ (DE 2\%). No entanto, a degradação efetiva para taxas de passagem de 3,5\%/h não mostrou diferença entre as épocas do ano. 
No período de verão a qualidade da planta foi melhor para o T1, pois a taxa de degradação da MS foi maior $(5,62 \% / \mathrm{h})$, assim como a DE 2\% (64,56\%), a DE 3,5\% $(56,66 \%)$ e a DP\% $(81,41 \%)$.

Tabela 4. Taxa de degradação (c), degradação efetiva com $2 \%$ de taxa de passagem (DE 2\%), degradação efetiva com 3,5\% de taxa de passagem (DE 3,5\%) e degradação potencial (DP\%) no rúmen para a matéria seca de amostras de pastejo simulado de capim Tanzânia (Panicum maximum Jacq.) irrigado coletadas em três épocas do ano (verão, outono e primavera) para três resíduos pós-pastejo (T1- Baixo; T2- Médio e T3- Alto).

\begin{tabular}{lcccc}
\hline Época do ano & T1 & T2 & T3 & Média \\
\hline \multirow{5}{c}{ Taxa de degradação (c) } \\
Verão & $5,62^{\mathrm{a}} \pm 0,20$ & $5,14^{\mathrm{a}} \pm 0,25$ & $4,52^{\mathrm{b}} \pm 0,24$ & 5,09 \\
Outono & $4,89^{\mathrm{a}} \pm 0,20$ & $3,93^{\mathrm{b}} \pm 0,24$ & $4,35 \pm 0,23$ & 4,39 \\
Primavera & $4,22 \pm 0,12$ & $4,66 \pm 0,14$ & $4,46 \pm 0,11$ & 4,45 \\
\multicolumn{5}{c}{ Degradação efetiva (DE $2 \%)$} \\
Verão & $64,56^{\mathrm{a}} \pm 0,77$ & $61,15^{\mathrm{b}} \pm 0,96$ & $60,07^{\mathrm{b}} \pm 0,76$ & $61,93^{\mathrm{A}}$ \\
Outono & $60,81^{\mathrm{a}} \pm 0,92$ & $57,11^{\mathrm{b}} \pm 0,97$ & $57,90^{\mathrm{b}} \pm 1,27$ & $58,60^{\mathrm{B}}$ \\
Primavera & $57,07 \pm 0,77$ & $58,24 \pm 1,06$ & $59,57 \pm 0,92$ & $58,30^{\mathrm{B}}$ \\
\multicolumn{5}{c}{ Degradação efetiva (DE $3,5 \%)$} \\
Verão & $56,66^{\mathrm{a}} \pm 0,95$ & $53,15^{\mathrm{b}} \pm 1,13$ & $52,12^{\mathrm{b}} \pm 0,85$ & 53,98 \\
Outono & $53,82^{\mathrm{a}} \pm 0,88$ & $49,82^{\mathrm{b}} \pm 0,97$ & $50,79^{\mathrm{b}} \pm 1,28$ & 51,47 \\
Primavera & $49,34^{\mathrm{b}} \pm 0,92$ & $51,12^{\mathrm{ab}} \pm 1,12$ & $52,86^{\mathrm{a}} \pm 1,18$ & 51,11 \\
\multicolumn{5}{c}{ Degradação potencial (DP\%) } \\
Verão & $81,41^{\mathrm{a}} \pm 0,57$ & $78,45^{\mathrm{b}} \pm 0,58$ & $78,07^{\mathrm{b}} \pm 0,80$ & $79,31^{\mathrm{A}}$ \\
Outono & $76,37 \pm 1,10$ & $74,25 \pm 0,93$ & $74,23 \pm 1,17$ & $74,95^{\mathrm{B}}$ \\
Primavera & $74,96 \pm 0,93$ & $74,27 \pm 0,74$ & $74,81 \pm 0,81$ & $74,68^{\mathrm{B}}$ \\
\hline
\end{tabular}

Médias seguidas da mesma letra minúscula na linha ou maiúscula na coluna não diferem significativamente pelo teste de Tukey $(\mathrm{P}>0,05)$.

Do verão para a primavera a maior queda de qualidade na forragem foi observada para o T1. Enquanto que, para o T2 e T3, a redução na digestibilidade potencial foi de menos de 4 pontos percentuais, para o T1 essa redução foi de 6,5 pontos percentuais. A redução da qualidade da forragem do T1 pode ser evidenciada pela 
avaliação da DE 3,5\%, onde, no verão, era maior para o T1 em relação ao T3, sendo que, na primavera, o T3 passa a ter maior DE 3,5\% que o T1.

A fração solúvel da FDN não mostrou diferenças significativas entre as épocas do ano, apesar da tendência de aumento de teor do verão para a primavera. Essa tendência de aumento no teor da fração A da FDN fica evidente no T1, onde para o verão foi de 5,42 \% MS e para a primavera foi de $14,00 \% \mathrm{MS}$. No verão, o maior teor da fração A foi para o T3, enquanto que na primavera o maior teor foi para o T1 (Tabela 5).

Tabela 5. Frações A, B, A+B e C da FDN incubada no rúmen de amostras simulando o pastejo de capim Tanzânia (Panicum maximum Jacq.) irrigado coletadas em três épocas ao longo do ano (verão, outono e primavera) para três resíduos pós-pastejo (T1- Baixo; T2- Médio e T3- Alto).

\begin{tabular}{lcccc}
\hline Época do ano & T1 & T2 & T3 & Média \\
\hline & & Fração A & \\
Verão & $5,42^{\mathrm{b}} \pm 1,49$ & $4,46^{\mathrm{b}} \pm 1,16$ & $9,80^{\mathrm{a}} \pm 1,31$ & 6,56 \\
Outono & $9,61^{\mathrm{a}} \pm 1,37$ & $8,43^{\mathrm{a}} \pm 1,62$ & $4,10^{\mathrm{b}} \pm 0,97$ & 7,38 \\
Primavera & $14,00^{\mathrm{a}} \pm 1,39$ & $8,81^{\mathrm{b}} \pm 0,84$ & $7,64^{\mathrm{b}} \pm 1,61$ & 10,15 \\
& & Fração B & \\
Verão & $75,64 \pm 1,38$ & $74,44 \pm 1,03$ & $73,14 \pm 1,16$ & $74,41^{\mathrm{A}}$ \\
Outono & $67,80 \pm 2,13$ & $66,90 \pm 2,02$ & $70,80 \pm 1,49$ & $68,50^{\mathrm{B}}$ \\
Primavera & $61,91 \pm 0,81$ & $64,26 \pm 0,78$ & $65,20 \pm 2,25$ & $63,79^{\mathrm{B}}$ \\
& & Fração A $+\mathrm{B}$ & \\
Verão & $81,06^{\mathrm{b}} \pm 0,63$ & $78,90^{\mathrm{c}} \pm 0,48$ & $82,93^{\mathrm{a}} \pm 0,25$ & $80,96^{\mathrm{A}}$ \\
Outono & $77,55 \pm 1,07$ & $75,32 \pm 1,50$ & $75,08 \pm 1,29$ & $75,98^{\mathrm{B}}$ \\
Primavera & $75,85 \pm 1,23$ & $74,21 \pm 1,02$ & $72,78 \pm 2,56$ & $74,28^{\mathrm{B}}$ \\
& & Fração C & \\
Verão & $19,07^{\mathrm{b}} \pm 0,70$ & $22,43^{\mathrm{a}} \pm 1,00$ & $16,72^{\mathrm{c}} \pm 0,41$ & $19,40^{\mathrm{B}}$ \\
Outono & $22,52 \pm 1,06$ & $24,68 \pm 1,50$ & $25,65 \pm 1,18$ & $24,29^{\mathrm{A}}$ \\
Primavera & $23,80 \pm 1,25$ & $25,80 \pm 0,98$ & $27,39 \pm 2,54$ & $25,66^{\mathrm{A}}$ \\
\hline
\end{tabular}

Médias seguidas da mesma letra minúscula na linha ou maiúscula na coluna não diferem significativamente pelo teste de Tukey $(\mathrm{P}>0,05)$.

A fração B e a soma de A e B foram maiores no período de verão quando comparados aos períodos de outono e primavera, da mesma forma que a fração $\mathrm{C}$ foi maior para o verão em relação ao outono e primavera. No verão, o T2 apresentou o 
menor teor da soma das frações A e B e o maior para a fração $\mathrm{C}$, enquanto que o T3 teve o maior teor para a soma $\mathrm{A}+\mathrm{B}$ e o menor para a fração $\mathrm{C}$.

Para a fração B não houve diferenças entre os tratamentos para nenhuma época do ano. A maior tendência de redução da fração B pôde ser verificada no T1, onde no verão o seu teor foi de 75,64 \% MS, enquanto que na primavera, 61,91\%MS.

A motivo pelo qual a DE 3,5\% não mostrou diferenças entre as épocas do ano, como foi o caso da DE $2 \%$, pode ser explicado pelo fato da taxa de passagem ter um maior efeito na degradação efetiva que a própria taxa de degradação. Assim, em animais com maior potencial de consumo e, portanto, com maiores taxas de passagem da dieta, o efeito na DE, entre alimentos com taxas de degradação diferentes, é minimizado.

A fração C do FDN, obtida pelo resíduo da degradação de 96 horas de incubação (Tabela 5), indica valores maiores que os obtidos pelo cálculo da lignina/FDN multiplicado por 2,4 (Tabela 2). Esse fator $(2,4)$, como já indicado por Traxler et al. (1998), mostra ser maior para plantas tropicais. Nesse caso, considerando os valores da Tabela 5, encontra-se como fator multiplicador da lignina os valores entre 2,91 e 3,35, sendo maior para a primavera, o que indica o mesmo teor de lignina alterando a disponibilidade da FDN de forma diferenciada.

Como pode ser visto na Tabela 6 a taxa de degradação da FDN se apresentou com tendência de redução do verão para a primavera. A redução na taxa de degradação provocou a queda da DE $2 \%, \mathrm{DE} 3,5 \%$ e da DP\% do verão para o outono e primavera. A redução das degradações do FDN entre as épocas do ano foi mais evidente para o T3, onde, do verão para a primavera, a DE $2 \%$ foi de 61,92 para $46,70 \%$, a DE $3,5 \%$ foi de 52,76 para $39,45 \%$ e a DP\% foi de 82,15 para $63,77 \%$.

Na primavera nenhum dos parâmetros de cinética ruminal avaliados mostrou diferenças entre os tratamentos, enquanto que, no verão, houve menores taxas de degradação (DE 2\%, DE 3,5\% e DP\%) para o T2. No outono, devido a maior queda da qualidade da FDN do T3, o T1 passou a apresentar as maiores degradações (Tabela 6).

O T3, do verão para a primavera, apresenta queda maior na qualidade da FDN que para MS, enquanto que a redução na qualidade da MS, para os T1 e T2, é mais próxima da queda de qualidade da FDN. 
Tabela 6. Taxa de degradação (c), degradação efetiva com $2 \%$ de taxa de passagem (DE 2\%), degradação efetiva com 3,5\% de taxa de passagem (DE 3,5\%) e degradação potencial (DP) para a FDN incubada no rúmen de amostras simulando o pastejo de capim Tanzânia (Panicum maximum Jacq.) irrigado coletadas ao longo do ano em três épocas (verão, outono e primavera).

\begin{tabular}{|c|c|c|c|c|}
\hline Época do ano & $\mathrm{T} 1$ & $\mathrm{~T} 2$ & T3 & Média \\
\hline \multicolumn{5}{|c|}{ Taxa de degradação (c) } \\
\hline Verão & $5,99^{a} \pm 0,20$ & $5,36^{\mathrm{b}} \pm 0,21$ & $5,11^{\mathrm{b}} \pm 0,18$ & 5,49 \\
\hline Outono & $5,19 \pm 0,36$ & $4,59 \pm 0,33$ & $4,68 \pm 0,44$ & 4,82 \\
\hline Primavera & $3,98 \pm 0,19$ & $3,74 \pm 0,50$ & $4,03 \pm 0,19$ & 3,91 \\
\hline \multicolumn{5}{|c|}{ Degradação efetiva (DE 2\%) } \\
\hline Verão & $61,87^{\mathrm{a}} \pm 0,96$ & $58,81^{\mathrm{b}} \pm 0,83$ & $61,92^{\mathrm{a}} \pm 0,76$ & $60,87^{\mathrm{A}}$ \\
\hline Outono & $60,10^{\mathrm{a}} \pm 0,80$ & $55,48^{\mathrm{b}} \pm 1,17$ & $52,42^{\mathrm{b}} \pm 2,16$ & $56,00^{\mathrm{B}}$ \\
\hline Primavera & $54,90 \pm 1,42$ & $52,70 \pm 1,90$ & $46,70 \pm 4,85$ & $51,40^{\mathrm{B}}$ \\
\hline \multicolumn{5}{|c|}{ Degradação efetiva (DE 3,5\%) } \\
\hline Verão & $52,87^{\mathrm{a}} \pm 1,09$ & $49,68^{b} \pm 0,96$ & $52,76^{\mathrm{a}} \pm 0,92$ & $51,77^{\mathrm{A}}$ \\
\hline Outono & $51,91^{\mathrm{a}} \pm 0,77$ & $46,90^{\mathrm{b}} \pm 1,10$ & $43,31^{b} \pm 2,31$ & $47,38^{\mathrm{B}}$ \\
\hline Primavera & $46.86 \pm 1,35$ & $44.51 \pm 1,82$ & $39.45 \pm 3,98$ & $43.61^{\mathrm{B}}$ \\
\hline \multicolumn{5}{|c|}{ Degradação potencial (DP \%) } \\
\hline Verão & $80,76^{\mathrm{b}} \pm 0,66$ & $78,45^{\mathrm{c}} \pm 0,51$ & $82,15^{\mathrm{a}} \pm 0,31$ & $80,45^{\mathrm{A}}$ \\
\hline Outono & $77,48^{\mathrm{a}} \pm 1,02$ & $74,87^{\mathrm{b}} \pm 1,19$ & $73,28^{\mathrm{b}} \pm 1,64$ & $75,21^{\mathrm{B}}$ \\
\hline Primavera & $73.55 \pm 1,70$ & $71.34 \pm 1,91$ & $63.77 \pm 7,02$ & $69.55^{\mathrm{B}}$ \\
\hline
\end{tabular}
não diferem significativamente pelo teste de Tukey $(\mathrm{P}>0,05)$.

No verão, houve maiores teores da porção FDA com potencial de degradação (B) que para as épocas de outono e primavera, consequentemente, os menores teores da fração C também ocorreram no verão (Tabela 7).

Assim como no caso da FDN, o T2 apresentou pior qualidade da composição da FDA, principalmente na primavera, onde a fração $\mathrm{C}$ foi maior quando comparada aos tratamentos 1 e 3 .

A fração A da FDA não mostra uma tendência clara de seus valores. No verão o T2 apresentou menor concentração (4,94 \%FDA) que não diferenciou do T1, enquanto 
que na primavera o tratamento de menor teor de fração solúvel da FDA foi o T3 $(6,26$ \%FDA) que não foi diferente do T1 (9,81 \%FDA).

Tabela 7. Frações $\mathrm{A}, \mathrm{B}, \mathrm{A}+\mathrm{B}$ e $\mathrm{C}$ da FDA incubada no rúmen de amostras simulando o pastejo de capim Tanzânia (Panicum maximum Jacq.) irrigado coletadas em três épocas ao longo do ano (Verão, Outono e Primavera) para três resíduos pós-pastejo (T1- Baixo; T2- Médio e T3- Alto).

\begin{tabular}{|c|c|c|c|c|}
\hline Época do ano & $\mathrm{T} 1$ & $\mathrm{~T} 2$ & T3 & Média \\
\hline \multicolumn{5}{|c|}{ Fração A } \\
\hline Verão & $8,96^{\mathrm{ab}} \pm 2,04$ & $4,94^{\mathrm{b}} \pm 1,17$ & $14,68^{\mathrm{a}} \pm 1,63$ & 9,53 \\
\hline Outono & $4,57 \pm 0,86$ & $2,86 \pm 0,82$ & $2,99 \pm 0,86$ & 3,47 \\
\hline Primavera & $9,81^{\mathrm{ab}} \pm 1,48$ & $\begin{array}{c}13,05^{\mathrm{a}} \pm 1,26 \\
\text { Fração B }\end{array}$ & $6,26^{b} \pm 1,64$ & 9,70 \\
\hline Verão & $72,70 \pm 1,85$ & $73,29 \pm 1,22$ & $70,49 \pm 1,73$ & $72,16^{\mathrm{A}}$ \\
\hline Outono & $70.99 \pm 1,35$ & $72,27 \pm 1,18$ & $71,98 \pm 1,08$ & $71,75^{\mathrm{A}}$ \\
\hline Primavera & $65,91^{\mathrm{a}} \pm 1,29$ & $\begin{array}{l}60,81^{\mathrm{b}} \pm 0,91 \\
\text { Fração A + B }\end{array}$ & $66,16^{\mathrm{a}} \pm 1,61$ & $64,30^{\mathrm{B}}$ \\
\hline Verão & $81,54^{\mathrm{a}} \pm 0,82$ & $78,54^{\mathrm{b}} \pm 1,08$ & $81,64^{\mathrm{a}} \pm 0,87$ & $80,57^{\mathrm{A}}$ \\
\hline Outono & $75,54 \pm 1,08$ & $75,44 \pm 1,09$ & $75,42 \pm 1,29$ & $75,47^{\mathrm{B}}$ \\
\hline Primavera & $76,02 \pm 0,95$ & $\begin{array}{c}75,40 \pm 0,78 \\
\text { Fração C }\end{array}$ & $73,45 \pm 1,10$ & $74,96^{\mathrm{B}}$ \\
\hline Verão & $18,33^{\mathrm{b}} \pm 0,82$ & $21,61^{\mathrm{a}} \pm 0,89$ & $17,17^{\mathrm{b}} \pm 0,68$ & $19,04^{\mathrm{B}}$ \\
\hline Outono & $24,59 \pm 1,06$ & $24,60 \pm 1,10$ & $25,11 \pm 1,16$ & $24,77^{\mathrm{A}}$ \\
\hline Primavera & $23,56 \pm 0,99$ & $24,89 \pm 0,78$ & $26,42 \pm 1,09$ & $24,96^{\mathrm{A}}$ \\
\hline
\end{tabular}

Médias seguidas da mesma letra minúscula na linha ou maiúscula na coluna não diferem significativamente pelo teste de Tukey $(\mathrm{P}>0,05)$.

Ao longo das épocas do ano, do verão para a primavera, ocorreu redução na taxa de degradação da FDA, de 5,38 para 3,54\%/h, respectivamente (Tabela 8). A redução na taxa de degradação promoveu reduções também nas DE 2\%, DE 3,5\% e DP\%. No verão as DE 2\%, DE 3,5\% e DP\% foram respectivamente de 61,44; 52,75 e 79,87\%. Enquanto que, na primavera, essas mesmas degradações foram de 54,57; 46,21 e 74,18\%, respectivamente. A qualidade da FDA seguiu a tendência de redução de qualidade do verão para a primavera, assim como o ocorrido para MS e FDN. 
Tabela 8. Taxa de degradação (c), degradação efetiva com $2 \%$ de taxa de passagem (DE 2\%), degradação efetiva com 3,5\% de taxa de passagem (DE 3,5\%) e degradação potencial (DP) para a FDA incubada no rúmen de amostras simulando o pastejo de capim Tanzânia (Panicum maximum Jacq.) irrigado coletadas ao longo do ano em três épocas (verão, outono e primavera).

\begin{tabular}{lcccc}
\hline Época do ano & T1 & T2 & T3 & Média \\
\hline \multirow{5}{c}{ Taxa de degradação (c) } \\
Verão & $6,22^{\mathrm{a}} \pm 0,22$ & $5,35^{\mathrm{ab}} \pm 0,25$ & $4,56^{\mathrm{b}} \pm 0,26$ & $5,38^{\mathrm{A}}$ \\
Outono & $5,03 \pm 0,32$ & $4,05 \pm 0,31$ & $3,56 \pm 0,36$ & $4,21^{\mathrm{AB}}$ \\
Primavera & $3,73 \pm 0,17$ & $3,42 \pm 0,30$ & $3,54 \pm 0,26$ & $3,56^{\mathrm{B}}$ \\
Verão & $63,77^{\mathrm{a}} \pm 0,96$ & $58,20^{\mathrm{b}} \pm 0,92$ & $62,35^{\mathrm{ab}} \pm 0,80$ & $61,44^{\mathrm{A}}$ \\
Outono & $56,10 \pm 1,06$ & $53,30 \pm 0,96$ & $49,90 \pm 2,12$ & $53,10^{\mathrm{B}}$ \\
Primavera & $54,50^{\mathrm{ab}} \pm 0,82$ & $57,21^{\mathrm{a}} \pm 1,18$ & $52,01^{\mathrm{b}} \pm 1,65$ & $54,57^{\mathrm{B}}$ \\
\multicolumn{5}{c}{ Degradação efetiva (DE $3,5 \%)$} \\
Verão & $55,35^{\mathrm{a}} \pm 1,17$ & $49,21^{\mathrm{b}} \pm 0,97$ & $53,70^{\mathrm{ab}} \pm 0,95$ & $52,75^{\mathrm{A}}$ \\
Outono & $47,30 \pm 1,02$ & $43,80 \pm 0,97$ & $40,50 \pm 2,16$ & $43,90^{\mathrm{B}}$ \\
Primavera & $45,79^{\mathrm{b}} \pm 0,89$ & $49,56^{\mathrm{a}} \pm 1,31$ & $43,27^{\mathrm{b}} \pm 1,82$ & $46,21^{\mathrm{B}}$ \\
\multicolumn{5}{c}{ Degradação potencial $(\mathrm{DP} \%)$} \\
Verão & $81,22^{\mathrm{a}} \pm 0,73$ & $77,49^{\mathrm{b}} \pm 1,11$ & $80,91^{\mathrm{a}} \pm 0,79$ & $79,87^{\mathrm{A}}$ \\
Outono & $75,15 \pm 1,12$ & $75,03 \pm 0,81$ & $71,90 \pm 1,80$ & $74,03^{\mathrm{B}}$ \\
Primavera & $74,87 \pm 0,86$ & $75,04 \pm 0,86$ & $72,63 \pm 1,15$ & $74,18^{\mathrm{B}}$ \\
\hline \multicolumn{5}{c}{ Médias } \\
\hline
\end{tabular}
não diferem significativamente pelo teste de Tukey $(\mathrm{P}>0,05)$.

A fração A da proteína bruta foi menor para a época da primavera $(28,60$ \% PB), enquanto que, a menor porção indisponível (fração $\mathrm{C}$ ) foi observada para o período de verão $(9,01 \% \mathrm{~PB})$. A maior fração indigestível foi encontrado na primavera (16,57 \%PB). A fração B não mostrou diferenças entre as épocas do ano, no entanto a soma de A e B foi maior para o verão comparada às outras épocas do ano.

Somente para o verão é que houve diferença na qualidade da proteína entre os tratamentos. O T2, no verão, apresentou menor proporção de A + B e maior proporção 
da fração C. A fração A foi maior para o T1 (41,33 \%PB) comparado ao T3 (33,86 $\%$ PB) (Tabela 9).

Tabela 9. Frações A, B, A+B e C da proteína bruta de amostras incubadas no rúmen simulando o pastejo de capim Tanzânia (Panicum maximum Jacq.) irrigado coletadas em três épocas ao longo do ano (verão, outono e primavera) para três resíduos pós-pastejo (T1- Baixo; T2- Médio e T3- Alto).

\begin{tabular}{lcccc}
\hline Época do ano & T1 & T2 & T3 & Média \\
\hline & & Fração A & \\
Verão & $41,33^{\mathrm{a}} \pm 1,31$ & $37,89^{\mathrm{ab}} \pm 2,41$ & $33,86^{\mathrm{b}} \pm 1,96$ & $37,69^{\mathrm{A}}$ \\
Outono & $36,20 \pm 1,69$ & $38,80 \pm 1,66$ & $34,00 \pm 2,85$ & $36,30^{\mathrm{A}}$ \\
Primavera & $28,60 \pm 3,43$ & $32,70 \pm 2,97$ & $24,50 \pm 2,47$ & $28,60^{\mathrm{B}}$ \\
& & Fração B & \\
Verão & $53,60 \pm 3,73$ & $52,00 \pm 2,23$ & $59,40 \pm 2,20$ & 55,00 \\
Outono & $48,90 \pm 1,61$ & $46,50 \pm 1,93$ & $57,70 \pm 4,72$ & 51,10 \\
Primavera & $55,40 \pm 3,20$ & $50,80 \pm 2,41$ & $57,60 \pm 2,54$ & 54,60 \\
& & Fração A $+\mathrm{B}$ & \\
Verão & $91,47^{\mathrm{a}} \pm 0,29$ & $89,93^{\mathrm{b}} \pm 0,24$ & $91,57^{\mathrm{a}} \pm 0,25$ & $90,99^{\mathrm{A}}$ \\
Outono & $86,32 \pm 0,58$ & $85,76 \pm 0,71$ & $85,77 \pm 0,61$ & $85,95^{\mathrm{B}}$ \\
Primavera & $83,94 \pm 0,91$ & $84,38 \pm 1,01$ & $82,05 \pm 1,55$ & $83,46^{\mathrm{B}}$ \\
& & Fração C & \\
Verão & $8,53^{\mathrm{b}} \pm 0,29$ & $10,07^{\mathrm{a}} \pm 0,24$ & $8,43^{\mathrm{b}} \pm 0,25$ & $9,01^{\mathrm{C}}$ \\
Outono & $13,66 \pm 0,58$ & $14,22 \pm 0,71$ & $14,23 \pm 0,61$ & $14,04^{\mathrm{B}}$ \\
Primavera & $16,10 \pm 1,02$ & $15,66 \pm 1,01$ & $17,95 \pm 1,55$ & $16,57^{\mathrm{A}}$ \\
\hline
\end{tabular}

Médias seguidas da mesma letra minúscula na linha ou maiúscula na coluna não diferem significativamente pelo teste de Tukey $(\mathrm{P}>0,05)$.

A taxa de degradação da proteína não se alterou entre as épocas do ano, no entanto, para o T1 houve tendência para ser menor na primavera que no verão. No verão e outono a taxa de degradação foi maior para o T1 comparado ao T2 e T3 (Tabela 10).

As degradações efetiva e potencial foram menores na primavera e maiores no verão. A DE $2 \%$ variou de $76,87 \%$ (no verão) a $68,08 \%$ (na primavera) e a $\mathrm{DE} 3,5 \%$ foi de 70,31 para 61,27\% entre o verão e a primavera, respectivamente. Da mesma forma, a DP\% variou entre 89,15 e $80,65 \%$, respectivamente para verão e primavera. 
Nos períodos de verão e outono o T1 apresentou as maiores DE $2 \%$ e DP\%. Nessas mesmas épocas do ano, o T3 teve a menor DE 3,5\%. Para a primavera não houve diferenças entre os tratamentos para taxa de degradação e degradações efetivas e potencial.

Tabela 10. Taxa de degradação (c), degradação efetiva com $2 \%$ de taxa de passagem (DE 2\%), degradação efetiva com 3,5\% de taxa de passagem (DE 3,5\%) e degradação potencial (DP) para a proteína bruta incubada no rúmen de amostras simulando o pastejo de capim Tanzânia (Panicum maximum Jacq.) em três épocas de coleta ao longo do ano (verão, outono e primavera).

\begin{tabular}{lcccc}
\hline Época do ano & T1 & T2 & T3 & Média \\
\hline \multirow{5}{c}{ Taxa de degradação (c) } \\
Verão & $6,63^{\mathrm{a}} \pm 0,31$ & $5,40^{\mathrm{b}} \pm 0,26$ & $5,36^{\mathrm{b}} \pm 0,19$ & 5,80 \\
Outono & $6,40^{\mathrm{a}} \pm 0,29$ & $4,73^{\mathrm{b}} \pm 0,38$ & $5,18^{\mathrm{b}} \pm 0,38$ & 5,43 \\
Primavera & $5,08 \pm 0,30$ & $5,11 \pm 0,29$ & $5,58 \pm 0,47$ & 5,26 \\
Verão & $78,92^{\mathrm{a}} \pm 0,96$ & $75,99^{\mathrm{b}} \pm 0,69$ & $75,69^{\mathrm{b}} \pm 0,78$ & $76,87^{\mathrm{A}}$ \\
Outono & $74,42^{\mathrm{a}} \pm 0,79$ & $71,77^{\mathrm{b}} \pm 0,73$ & $69,44^{\mathrm{b}} \pm 1,43$ & $71,87^{\mathrm{B}}$ \\
Primavera & $67,96 \pm 1,32$ & $69,42 \pm 1,23$ & $66,85 \pm 1,96$ & $68,08^{\mathrm{C}}$ \\
\multicolumn{5}{c}{ Degradação efetiva (DE $3,5 \%)$} \\
Verão & $72,82^{\mathrm{a}} \pm 1,37$ & $69,67^{\mathrm{a}} \pm 0,93$ & $68,43^{\mathrm{b}} \pm 1,04$ & $70,31^{\mathrm{A}}$ \\
Outono & $68,74^{\mathrm{a}} \pm 1,00$ & $65,76^{\mathrm{ab}} \pm 0,79$ & $62,29^{\mathrm{b}} \pm 1,90$ & $65,60^{\mathrm{B}}$ \\
Primavera & $60,98 \pm 1,65$ & $63,00 \pm 1,53$ & $59,84 \pm 2,31$ & $61,27^{\mathrm{C}}$ \\
\multicolumn{5}{c}{ Degradação potencial (DP $\%)$} \\
Verão & $90,32^{\mathrm{a}} \pm 0,34$ & $87,79^{\mathrm{c}} \pm 0,29$ & $89,35^{\mathrm{b}} \pm 0,33$ & $89,15^{\mathrm{A}}$ \\
Outono & $85,02^{\mathrm{a}} \pm 0,58$ & $82,86^{\mathrm{b}} \pm 0,83$ & $82,65^{\mathrm{b}} \pm 0,83$ & $83,51^{\mathrm{B}}$ \\
Primavera & $80,88 \pm 0,89$ & $81,37 \pm 0,82$ & $79,72 \pm 1,40$ & $80,65^{\mathrm{C}}$ \\
\hline
\end{tabular}

Médias seguidas da mesma letra minúsculo na linha ou maiúscula na coluna não diferem significativamente pelo teste de Tukey $(\mathrm{P}>0,05)$.

A fração A do nFDN foi de pequena proporção e não apresentou diferenças entre os tratamentos e épocas do ano (Tabela 11). As frações B e a soma de A e B foram maiores para o verão, consequentemente, a fração $\mathrm{C}$ foi menor para esse período em relação às épocas de outono e primavera. No verão as frações B, A + B e C foram, respectivamente, de 75,19; 75,32 e 24,68 \%nFDN. 
A fração $\mathrm{C}$ da nFDN indica a porção de proteína que está aderida à parede celular que não pode ser degradada. Por determinação "líquida" esse valor representa o nFDA, que apresentou variação de 6,48 a 10,70\% (Tabela 2). No entanto, considerando a concentração de nFDN na PB e os teores da fração C indicados na Tabela 11, obtêm-se teores entre 12,11 e 17,08 \% PB para a fração indegradável da proteína, ou seja, valores maiores que os obtidos em laboratório. Isso indica algum erro de laboratório na determinação dessa fração.

Tabela 11. Frações $\mathrm{A}, \mathrm{B}, \mathrm{A}+\mathrm{B}$ e $\mathrm{C}$ da nFDN incubada no rúmen de amostras simulando o pastejo de capim Tanzânia (Panicum maximum Jacq.) coletadas em três épocas ao longo do ano (verão, outono e primavera) para três resíduos pós-pastejo (T1Baixo; T2- Médio e T3- Alto).

\begin{tabular}{lcccc}
\hline Época do ano & T1 & T2 & T3 & Média \\
\hline Verão & 3,01 & Fração A & \\
Outono & $2,32 \pm 1,11$ & $3,38 \pm 1,11$ & $2,26 \pm 1,10$ & 0,13 \\
Primavera & $3,03 \pm 1,51$ & $4,41 \pm 1,18$ & $5,95 \pm 1,49$ & 4,46 \\
& & Fração B & & \\
Verão & $74,49 \pm 1,30$ & $72,93 \pm 0,88$ & $78,16 \pm 0,71$ & $75,19^{\mathrm{A}}$ \\
Outono & $67,15 \pm 1,13$ & $64,00 \pm 2,09$ & $62,64 \pm 21,8$ & $64,60^{\mathrm{B}}$ \\
Primavera & $68,47 \pm 1,86$ & $63,17 \pm 1,26$ & $65,82 \pm 0,75$ & $65,82^{\mathrm{B}}$ \\
& & Fração A + B & & \\
Verão & $77,50^{\mathrm{a}} \pm 0,98$ & $72,70^{\mathrm{b}} \pm 1,20$ & $75,77^{\mathrm{a}} \pm 1,10$ & $75,32^{\mathrm{A}}$ \\
Outono & $69,28 \pm 1,39$ & $67,46 \pm 1,70$ & $65,05 \pm 2,08$ & $67,27^{\mathrm{B}}$ \\
Primavera & $70,44 \pm 2,02$ & $67,81 \pm 1,48$ & $72,68 \pm 1,82$ & $70,31^{\mathrm{B}}$ \\
& & Fração C & & \\
Verão & $22,50^{\mathrm{b}} \pm 0,98$ & $27,30^{\mathrm{a}} \pm 1,20$ & $24,23^{\mathrm{ab}} \pm 1,10$ & $24,68^{\mathrm{A}}$ \\
Outono & $30,72 \pm 1,39$ & $32,08 \pm 1,74$ & $34,95 \pm 2,08$ & $32,58^{\mathrm{B}}$ \\
Primavera & $29,56 \pm 2,02$ & $32,19 \pm 1,48$ & $27,32 \pm 1,82$ & $29,69^{\mathrm{B}}$ \\
\hline
\end{tabular}

Médias seguidas da mesma letra minúsculo na linha ou maiúscula na coluna não diferem significativamente pelo teste de Tukey $(\mathrm{P}>0,05)$.

Na Tabela 12, observa-se, para o nFDN, maiores taxas de degradação, maior $\mathrm{DE} 2 \%$, maior $\mathrm{DE} 3,5 \%$ e maior $\mathrm{DP} \%$ para o verão quando comparado ao outono e 
primavera. $\mathrm{O} \mathrm{nFDN}$ é a porção da planta que, em relação à cinética ruminal, mais apresentou alteração ao longo das estações do ano. Sua taxa de degradação que era de $6,49 \% / \mathrm{h}$ para o verão se reduziu para $3,62 \% / \mathrm{h}$ na primavera. A DE $2 \%$ apresentou redução de 10,50 pontos percentuais, enquanto que a DE 3,5\%, 11,38 pontos percentuais do verão para a primavera.

Tabela 12. Taxa de degradação (c), degradação efetiva com $2 \%$ de taxa de passagem (DE 2\%), degradação efetiva com 3,5\% de taxa de passagem (DE 3,5\%) e degradação potencial (DP) para a nFDN incubada no rúmen de amostras simulando o pastejo de capim Tanzânia (Panicum maximum Jacq.) coletadas ao longo do ano em três épocas (verão, outono e primavera).

\begin{tabular}{lcccc}
\hline Época do ano & T1 & T2 & T3 & Média \\
\hline \multicolumn{5}{c}{ Taxa de degradação (c) } \\
Verão & $6,62 \pm 0,44$ & $6,38 \pm 0,65$ & $6,46 \pm 0,47$ & $6,49^{\mathrm{A}}$ \\
Outono & $4,81^{\mathrm{a}} \pm 0,66$ & $3,92^{\mathrm{a}} \pm 0,47$ & $2,99^{\mathrm{b}} \pm 0,31$ & $3,91^{\mathrm{B}}$ \\
Primavera & $3,61 \pm 0,31$ & $3,71 \pm 0,37$ & $3,53 \pm 0,25$ & $3,62^{\mathrm{B}}$ \\
Verão & $60,86^{\mathrm{a}} \pm 1,02$ & $55,93^{\mathrm{b}} \pm 1,77$ & $57,20^{\mathrm{b}} \pm 1,28$ & $58,00^{\mathrm{A}}$ \\
Outono & $48,90^{\mathrm{a}} \pm 1,43$ & $46,60^{\mathrm{a}} \pm 1,65$ & $39,70^{\mathrm{b}} \pm 1,14$ & $45,10^{\mathrm{B}}$ \\
Primavera & $48,30 \pm 1,68$ & $50,60 \pm 1,50$ & $43,50 \pm 1,34$ & $47,50^{\mathrm{B}}$ \\
\multicolumn{5}{c}{ Degradação efetiva (DE 3,5\%) } \\
Verão & $52,41^{\mathrm{a}} \pm 1,17$ & $47,51^{\mathrm{b}} \pm 2,02$ & $47,92^{\mathrm{b}} \pm 1,45$ & $49,28^{\mathrm{A}}$ \\
Outono & $40,60^{\mathrm{a}} \pm 1,62$ & $38,40^{\mathrm{a}} \pm 1,60$ & $31,10^{\mathrm{b}} \pm 1,14$ & $36,70^{\mathrm{B}}$ \\
Primavera & $39,20^{\mathrm{a}} \pm 1,76$ & $42,30^{\mathrm{a}} \pm 1,47$ & $35,10^{\mathrm{b}} \pm 1,27$ & $38,90^{\mathrm{B}}$ \\
\multicolumn{5}{c}{ Degradação potencial (DP \%) } \\
Verão & $77,85^{\mathrm{a}} \pm 0,74$ & $73,11^{\mathrm{b}} \pm 1,09$ & $76,78^{\mathrm{a}} \pm 0,93$ & $75,91^{\mathrm{A}}$ \\
Outono & $67,68^{\mathrm{a}} \pm 1,26$ & $65,30^{\mathrm{ab}} \pm 1,72$ & $60,94^{\mathrm{b}} \pm 1,68$ & $64,64^{\mathrm{B}}$ \\
Primavera & $69,80^{\mathrm{a}} \pm 1,84$ & $69,50^{\mathrm{a}} \pm 1,52$ & $64,10^{\mathrm{b}} \pm 1,70$ & $67,80^{\mathrm{B}}$ \\
\hline
\end{tabular}

Médias seguidas da mesma letra minúsculo na linha ou maiúscula na coluna não diferem significativamente pelo teste de Tukey $(\mathrm{P}>0,05)$.

Não houve diferenças entre os tratamentos para taxas de degradação, a não ser para a época de outono, onde foi menor para o T3. As degradações efetivas e potencial tiveram uma tendência de serem maiores em todas épocas do ano para o T1 em 
comparação ao T2 e T3. A DE $2 \%$ e DE 3,5\% apresentaram grande variação do maior para o menor valor, 21,16 e 21,31 pontos percentuais, respectivamente.

A análise de correlação simples de alguns parâmetros com as taxas de degradação indica que, para MS, FDN e FDA, não existe, na análise nutricional dessas forragens, uma fração que se destaque na explicação da degradabilidade ruminal. No caso da MS, o teor de FDN explica apenas 9\% de sua degradação. A lignina que deveria ser o melhor parâmetro para se explicar a degradação da MS apresenta coeficiente de degradação muito baixo $(16,64)$.

Os teores de FDN, FDA, Hemicelulose e lignina praticamente não apresentaram correlação com as degradações de FDN e FDA (Tabela 13).

Tabela 13. Correlações da digestibilidade, para taxas de passagem de 3,5\%/h da MS (DE 3,5\%), FDN (DE 3,5\%), FDA (DE 3,5\%), PB (DE 35,\%) e nFDN (DE 3,5\%) com frações da parede celular e da proteína de amostras de capim Tanzânia (Panicum maximum Jacq.) irrigado.

\begin{tabular}{lccccc}
\hline & MS & FDN & FDA & PB & NFDN \\
\hline FDN & $-30,49$ & 5,81 & $-7,28$ & & \\
FDA & 30,31 & $-5,71$ & 7,14 & & \\
Hemicelulose & 30,46 & 5,64 & 7,32 & & \\
Lignina & $-16,64$ & 12,56 & $-11,40$ & $-32,71$ & 32,47 \\
PB & & & & $-29,11$ & 22,57 \\
NFDN & & & & $-52,20$ & 20,56 \\
NnP & & & & 23,92 & $-1,54$ \\
NFDA & & & & $-1,20$ & 20,34 \\
Nsol & & & & 24,24 & 9,23 \\
Correlação canônica & 51,60 & 21,34 & 25,49 & 73,91 & 43,34 \\
\hline
\end{tabular}

A degradação da proteína bruta, no entanto, é em grande parte explicada por suas frações (Nsol, NnP, nFDN) e pelo seu teor, principalmente, pela concentração de 
nFDN, que representa em torno de $50 \%$ da PB e explica $25 \%$ da degradação da proteína. Quanto maior o teor de nFDN menor foi a degradação da PB, da mesma forma que quanto maior a proporção de proteína na planta, pior foi sua degradação. Por outro lado, quanto maior a proporção de $\mathrm{NnP}$ e Nsol, maior foi a degradabilidade ruminal da proteína. O nFDA não teve boa correlação com a degradação da proteína, talvez por seu baixo teor nas plantas (menor que $10 \%$ da PB). Essa baixa correlação do nFDA com a qualidade da proteína coloca em dúvida a análise dessa fração nesse tipo de forrageira.

A lignina apresenta correlação moderada, tanto para a degradabilidade da PB como do nFDN. Para a PB a correlação é negativa, o coeficiente de correlação é de 32,71. Entretanto, para o nFDN, além da correlação ser baixa $(32,47)$, ela é positiva. Isso demonstra a variabilidade da análise de lignina e a importância de se conhecer com maior detalhe essa fração.

A correlação canônica (correlação múltipla) entre a degradação da PB e os teores de lignina, PB, nFDN, NnP, nFDA e Nsol, apresenta coeficiente de 73,91\%. Isso significa que mais de $50 \%$ da degradação da PB é explicada por esses parâmetros. No caso da MS, a correlação múltipla de sua degradação com o teor de FDN, FDA, hemicelulose e lignina apresenta boa correlação $(51,60 \%)$. No entanto, a correlação positiva de teor da FDA com degradação da MS fica difícil de ser explicada.

A correlação múltipla das degradações do nFDN, FDN e da FDA são relativamente baixas, 43,34; 21,34 e 25,49, respectivamente, devendo existir outros parâmetros que melhor possam explicar essas degradações.

Considerando a degradação efetiva, para taxa de passagem de 3,5\%/h, tanto para PB como para MS, e somando-se a parte solúvel (fração A), observa-se que a degradação ruminal da MS (MSD) varia entre 50,88 e 47,80 para verão e primavera, respectivamente. Em relação a $\mathrm{PB}$, o mesmo raciocínio indica degradação ruminal (PDR) entre 76,36 e 62,05\% da PB. Isso significa que em torno de 8 e $9 \%$ MS é PDR (Tabela 14).

A relação da PDR com a matéria orgânica digerida no rúmen é um parâmetro usado na sincronização ruminal entre carboidratos e proteína (NRC, 1990; Poppi \& McLennan, 1995). É recomendado que esse valor seja próximo de 13\%. Nesse caso, não 
é possível a correção dos valores para MODR, sendo, portanto, a relação expressa em MSD. Assim, a relação PDR/MSD é da ordem de 16 a $19 \%$.

A relação PDR/MSD deve ser levada em consideração em uma eventual suplementação concentrada para animais pastejando esse tipo de forragem. Pode se dizer que, nesse caso, não seria aconselhável trabalhar com uréia, pois, já existe proteína de rápida degradação em excesso. A relação da fração A da proteína com a fração A da MS (entre 19,51 e 26,58\%) indica que há uma desproporção entre essas frações, uma vez que apresentam taxas de degradação semelhantes.

Tabela 14. Relações entre proteína e MS degradável (DE 3,5\%) no rúmen de amostras simulando o pastejo de capim Tanzânia (Panicum maximum Jacq.) irrigado.

\begin{tabular}{lccc}
\hline & Verão & Outono & Primavera \\
\hline & \multicolumn{2}{c}{ Proteína } & \\
Fração A \% MS & 4,44 & 4,14 & 4,17 \\
Fração B \% MS & 4,54 & 3,83 & 4,90 \\
PDR \% MS & 8,98 & 7,97 & 9,07 \\
& \multicolumn{2}{c}{ Matéria seca } & \\
Fração A \% MS & 16,70 & 21,22 & 19,34 \\
Fração B \% MS & 34,18 & 28,06 & 28,46 \\
MSD \% MS & 50,88 & 49,28 & 47,80 \\
& Relações (proteína/MS) & \\
Fração A & 26,58 & 19,51 & 21,56 \\
Fração B & 13,28 & 13,65 & 17,22 \\
PDR/MSD & 17,65 & 16,17 & 18,97 \\
\hline
\end{tabular}

Por outro lado, a fração potencialmente degradável (B) da MS e da PB apresentam relações entre 13,28 e 17,22\%. Essa relação, apesar de não estar corrigida para MO, parece estar adequada, embora considerando-se taxa de passagem menor a tendência é dessa relação se reduzir. 
Desse modo, a suplementação concentrada em pastagens de capim Tanzânia adubado e irrigado, deve ter dois objetivos: em um primeiro momento adição de carboidratos solúveis de rápida degradação ruminal; segundo, adição de proteína de boa qualidade e de degradação moderada.

\subsection{Conclusões}

O período de verão (dezembro e janeiro) apresentou a melhor qualidade da forragem quando comparada com as forragens amostradas em abril (outono) e outubro (primavera).

Houve tendências para o tratamento de menor resíduo pós-pastejo (T1) apresentar melhor qualidade no verão, no entanto do verão para a primavera foi o tratamento que apresentou maior redução de digestibilidade.

Para o T3 a redução na digestibilidade da FDN foi em maior proporção que para a MS, quando comparada aos outros tratamentos (T1 e T2).

A fração prontamente solúvel da proteína pode ser maior que $40 \%$ da PDR. A PDR variou entre 76,36 e 62,05\% PB.

A fração $\mathrm{C}$ da FDN é maior que a fração $\mathrm{C}$ calculada pelo método adotado pelo programa de Cornell, indicando que o fator de multiplicação da FDN deve ser maior que 2,4, sugerindo que esse valor deveria estar entre 2,91 e 3,35.

A fração $\mathrm{C}$ do nFDN é maior que a calculada em laboratório como sendo nFDA, isso indica erros na determinação do nFDA.

Não há um parâmetro de qualidade nutricional que justifique adequadamente a cinética ruminal, tanto para MS, FDN, FDA, PB e nFDN. A degradação da proteína é bem explicada pelos teores de PB e de suas frações. Quanto maior o teor de PB e de nFDN, pior foi a digestibilidade da PB.

Uma eventual suplementação com concentrados para animais em pastagens irrigadas de capim Tanzânia deve optar por carboidratos de rápida solubilidade ou por proteínas de boa qualidade e de lenta degradação. 


\section{CONSUMO DE FORRAGEM POR ANIMAIS NELORE EM CRESCIMENTO EM PASTAGENS DE CAPIM TANZÂNIA IRRIGADO SOB TRÊS RESÍDUOS PÓS-PASTEJO.}

\section{Resumo}

O consumo de forragem por novilhos nelore castrados, em pastagens de capim Tanzânia irrigado, foi estimado em três estações do ano (verão, outono e primavera), utilizando-se o óxido de cromo como marcador. Foi testado o efeito de três níveis de resíduo pós-pastejo $(\mathrm{T} 1=1267 \mathrm{~kg}$ matéria seca verde/ha; T2= $2914 \mathrm{~kg}$ matéria seca verde/ha; T3= $4256 \mathrm{~kg}$ matéria seca verde/ha). Não houve interação entre estações do ano e resíduo pós-pastejo. O consumo de forragem foi menor para o tratamento $1(65,8$ g/kg PM) e para o período de primavera (61,3 g/kg PM). Em média, o consumo de FDN foi de $1,34 \%$ do peso animal. A altura do resíduo pós-pastejo, a oferta de folhas e a MSD explicaram, em média, 50\% do consumo de forragem nas três estações do ano. No período do verão, houve aumento no consumo de forragem com o aumento da altura de pastejo e da oferta de folhas. Ainda no período de verão, o consumo máximo de forragem $(82,98 \mathrm{~g} / \mathrm{kg} \mathrm{PM})$ foi obtido com um resíduo de $2833 \mathrm{~kg} / \mathrm{ha}$ de matéria seca verde. A relação PDR/MDOR foi, em média, de 16,81\%, gerando um excesso de $\mathrm{N}$ ruminal entre 4 e $29 \%$. O programa de Cornell superestimou o consumo de matéria seca entre 3,80 e $55 \%$.

\section{Summary}

The objective of this work was to estimate forage intake by Nellore growing steers of Tanzania grass (Panicum maximum Jacq.) on three periods (spring, summer 
and fall) on irrigated paddocks, rotationally grazed to three post grazing green dry matter residues $(\mathrm{GDMR})(\mathrm{T} 1=$ low, $\mathrm{T} 2=$ medium and $\mathrm{T} 3=$ high. The low post grazing residue and the spring time showed the lowest forage intake $(65.8$ and $61.3 \mathrm{~g} / \mathrm{kg} \mathrm{PM}$, respectively). On the average the NDF intake was $1.34 \%$ of live weight. The post grazing height, leaf allowance and digestible dry matter explained $50 \%$ of forage intake. The forage intake increased as both the post grazing and leaf allowance increased during the summer. The estimated maximum forage intake $(82.98 \mathrm{~g} / \mathrm{kg} \mathrm{PM})$ during the summer was obtained with a post-grazing residue of $2,833 \mathrm{~kg} / \mathrm{ha}$ of GDMR. The estimated range of RDP/RDOM ratio was from 15.02 to 19.18 , which indicates an excess of rumen nitrogen of 4 to $29 \%$. Overall the forage intake was overestimated in 3.8 to $55 \%$ by the CNCPS.

\subsection{Introdução}

Conhecer o consumo de matéria seca de animais sob pastejo é de fundamental importância em qualquer programa nutricional. Os fatores nutricionais da forragem e os aspectos físicos da pastagem que interferem no consumo de matéria seca de animais sob pastejo devem ser entendidos. Assim, conhecendo-se o consumo de matéria seca e como

manipular as principais características das pastagens é possível definir melhor o balanceamento de dietas, uma vez que a definição do consumo por animais em pastejo permite: formular rações, prever o desempenho animal e estimar a demanda de alimentos ou exigências (Mertens, 1994).

O teor de FDN está correlacionado o com consumo máximo de matéria seca. Mertens (1994) coloca que a máxima ingestão de MS se dá quando o consumo de FDN atinge 1,25 +/- 0,10 \% do peso animal/dia, apesar do consumo de MS não estar relacionado com teor de FDN, pois essa correlação apresenta baixo coeficiente $(-0,12)$. Além disso, Mertens (1994), indica que não seria possível consumos de FDN acima de $1,25 \%$ do peso animal/dia, pois, acima desse ponto o consumo estaria limitado pelo aspecto físico. 
No entanto, Ruiz et al. (1995), obtiveram aumento linear de consumo de FDN de 1,15 para $1,32 \%$ do peso animal/dia, quando se passou de uma dieta de 31 para $39 \%$ de FDN na MS, onde a base de volumosos era silagens de capins tropicais.

Em pastagens de Capim-elefante (Pennisetum purpureum Schum.) com teores de FDN entre 63 e 67\% MS, os consumos de FDN para vacas em lactação foram entre 1,28 e $1,58 \%$ do peso animal/dia (Balsalobre, 1996).

A quantidade de resíduo pós-pastejo interfere no consumo de matéria seca de animais sob pastejo. Trabalhos em pastagens de clima temperado mostram consumos crescentes até aproximadamente $2000 \mathrm{~kg}$ MS/ha de resíduo pós-pastejo (Holmes\& Wilson, 1984). Da mesma forma, em condições tropicais, Almeida et al. (2000), indicam que com Capim-elefante anão a disponibilidade de forragem deve estar compreendida entre 10,5 e $14,7 \mathrm{~kg}$ de MS de lâminas de folhas verdes para cada $100 \mathrm{~kg}$ de peso animal/dia para garantir perenidade da planta forrageira. Esses valores de oferta de forragem correspondem aproximadamente a 2000 e $2500 \mathrm{~kg}$ de lâmina verde de resíduo pós-pastejo.

A relação assintótica entre consumo de forragem e resíduo pós-pastejo, permite inferir sobre a possibilidade de se planejar sistemas de pastejo mais eficientes, tanto na utilização da forragem disponível, como no desempenho animal. Resíduos póspastejo maiores promovem maiores desempenhos individuais, enquanto que resíduos menores limitam o consumo de forragem pelos animais, o que proporciona menores desempenhos individuais. No entanto, em resíduos menores haverá capacidade para maiores lotações, o que poderá levar a um maior grau de eficiência de utilização da forragem pelos animais.

Combellas \& Hodgson (1979) indicam que para pressões de pastejo de 3; 6 e $9 \%$, onde obviamente os resíduos foram maiores quanto menor a pressão de pastejo, a eficiência no consumo da forragem disponível foi de 85\%; $49 \%$ e 33\%, respectivamente.

Considerando que o tempo de pastejo dos animais durante o dia é limitado em, no máximo, 9 horas e que dificilmente um animal consegue dar mais que 4000 bocados por hora (Stobbs, 1973), o tamanho de cada bocado é que pode definir o consumo de forragem por um animal. 
O tamanho de cada bocado parece estar relacionado mais com a profundidade de cada bocado no dossel do que com a área do bocado (Burlison et al., 1991). Segundo Hodgson et al. (1994), a profundidade do bocado é proporcional à altura da pastagem. No entanto, Laca et al. (1993) encontraram uma resposta de acréscimos decrescentes de consumo relacionado à altura da forragem.

Costa et al. (2001) não encontraram diferenças na taxa de bocados quando pastagens de Tanzânia foram pastejadas em três alturas: 52,85; 68,36; 74,71 cm (média de três dias de pastejo). No entanto, para o tratamento de menor altura de pastejo o tempo de pastejo foi maior, provavelmente uma forma dos animais compensarem o menor tamanho de bocado em pastagens mais baixas.

Carvalho et al. (2001), mostram que plantas altas podem promover redução no consumo de forragem por ovelhas devido a redução na velocidade de ingestão de cada bocado. Pastagens de Tanzânia manejadas em três resíduos: baixo $(15 \mathrm{~cm})$, médio (24 $\mathrm{cm})$ e alto $(60 \mathrm{~cm})$, que representaram, respectivamente, massa de forragem de 2673, 2981 e $4255 \mathrm{~kg} \mathrm{MS} / \mathrm{ha}$, mostraram um aumento no tempo de cada bocado de 1,85 s, para o resíduo baixo para 2,55 s, para o mais alto. Carvalho et al. (2001) ressaltam que mesmo o tamanho do bocado sendo maior para as maiores alturas de resíduo, a menor taxa de ingestão pode levar a menores consumos em maiores disponibilidades de forragem.

A influência da altura da pastagem, analisada nos três dias de pastejo de uma mesma área de capim Tanzânia, mostra maior tempo de pastejo para o primeiro dia de ocupação (10,08 horas para uma altura de $83,50 \mathrm{~cm}$ ), comparado ao terceiro dia de pastejo (8,57 horas para 46,05 $\mathrm{cm}$ de altura). Além disso, observa-se menor taxa de bocados para o terceiro dia de pastejo (1263 bocados/hora), comparado ao primeiro dia (1546 bocados/hora) (Costa et al., 2001).

Esse trabalho tem por objetivo avaliar o consumo de forragem em pastagem de capim Tanzânia (Panicum maximum Jacq.) irrigado em três estações do ano (verão, outono e primavera) e sob três níveis de resíduo pós-pastejo (Baixo, Médio e Alto). Este estudo também procurou fazer uma avaliação do programa de Cornell para predição do consumo, desempenho animal e simulação de suplementação concentrada. 


\subsection{Material e Métodos}

O experimento foi conduzido na Fazenda Areão da Escola Superior de Agricultura "Luiz de Queiroz" da Universidade de São Paulo, em Piracicaba, São Paulo ( $22^{0} 42^{\prime} 30^{\prime \prime}$ lat. S; 47 38'00" long. W; 546 m altitude). A forragem utilizada foi o capim Tanzânia (Panicum maximum Jacq.) estabelecido em área irrigada através de pivô central. A pastagem foi manejada através de pastejo rotacionado com 33 dias de descanso e três dias de ocupação. Os tratamentos, com quatro repetições, foram constituídos de três níveis de resíduo pós-pastejo, a saber: T1 - Baixo, T2 - Médio e T3 - Alto. Os valores de resíduo pós-pastejo ao longo do ano constam da Tabela 1. Para cada tratamento havia 12 parcelas de $1330 \mathrm{~m}^{2}$ distribuídos em quatro blocos, sendo cada parcela subdividida em três piquetes para facilitar o manejo.

Tabela1. Resíduo pós-pastejo em kg de MS verde/ha em quatro épocas do ano para pastagens de capim Tanzânia (Panicum maximum Jacq.) sob três níveis de resíduo pós-pastejo (T1- Baixo, T2- Médio e T3- Alto) em área irrigada.

\begin{tabular}{lllll}
\hline Tratamento & Época 1 & Época 2 & Época 3 & Época 4 \\
\hline T1 & $1277^{\mathrm{Aab}}$ & $1763^{\mathrm{Aab}}$ & $816^{\mathrm{Ab}}$ & $1210^{\mathrm{Aba}}$ \\
$\mathrm{T} 2$ & $2459^{\mathrm{Ba}}$ & $3346^{\mathrm{Bb}}$ & $2548^{\mathrm{Bab}}$ & $3306^{\mathrm{Bb}}$ \\
$\mathrm{T} 3$ & $3106^{\mathrm{Ca}}$ & $5335^{\mathrm{Cb}}$ & $3113^{\mathrm{Ca}}$ & $5471^{\mathrm{Cb}}$ \\
\hline
\end{tabular}

Época 1 - 29/10/1999 a 14/02/2000

Época 2 - 15/02/2000 a 02/06/2000

Época 3 - 03/06/2000 a 13/08/2000

Época 4 - 18/09/2000 a 29/11/2000

Médias seguidas da mesma letra maiúscula na coluna ou minúscula na linha não diferem significativamente $(\mathrm{P}>0,05)$.

O solo foi corrigido para garantir os seguintes níveis de fertilidade: saturação por bases, $80 \%$; fósforo, $30 \mathrm{mg} / \mathrm{dm}^{3}$; potássio, $5 \%$ da CTC. Imediatamente após cada 
pastejo os piquetes foram adubados com $80 \mathrm{~kg} / \mathrm{ha}$ de $\mathrm{N}$ e $80 \mathrm{~kg} / \mathrm{ha}$ de $\mathrm{K}_{2} \mathrm{O}$ em todos os ciclos de pastejo ao longo de 1 ano.

A composição nutricional da forragem para as diferentes estações do ano consta da Tabela 2. Como não houve diferenças entre os tratamentos, os valores expressam as médias dos três tratamentos em cada estação do ano.

Tabela 2. Composição nutricional de amostras do pastejo simulado de capim Tanzânia (Panicum maximum Jacq.) sob três níveis de resíduo pós-pastejo (T1- Baixo, T2- Médio e T3- Alto) e em três estações do ano (verão, outono e primavera).

\begin{tabular}{lccc}
\hline & Verão & Outono & Primavera \\
\hline & Componentes da parede celular & \\
FDN \% MS & 66,15 & 65,60 & 64,52 \\
FDA \% MS & 33,18 & 34,31 & 34,63 \\
Lignina \% MS & $3,34^{\mathrm{b}}$ & $3,87^{\mathrm{a}}$ & $3,85^{\mathrm{a}}$ \\
Fração B2 \% CT & $70,35^{\mathrm{a}}$ & $67,53^{\mathrm{ab}}$ & $65,14^{\mathrm{b}}$ \\
Fração C \% CT & 16,00 & 18,43 & 18,96 \\
& Componentes protéicos & \\
PB \% MS & $11,77^{\mathrm{b}}$ & $11,41^{\mathrm{b}}$ & $14,61^{\mathrm{a}}$ \\
Nsol \% PB & $26,75^{\mathrm{b}}$ & $26,70^{\mathrm{b}}$ & $35,97^{\mathrm{a}}$ \\
NnP \% PB & $21,84^{\mathrm{b}}$ & $22,26^{\mathrm{ab}}$ & $28,77^{\mathrm{a}}$ \\
nFDN \% PB & 49,10 & 52,43 & 49,07 \\
nFDA \% PB & $10,70^{\mathrm{a}}$ & $8,94^{\mathrm{b}}$ & $6,48^{\mathrm{b}}$ \\
Fração B2 \% PB & $24,14^{\mathrm{a}}$ & $20,87^{\mathrm{a}}$ & $14,96^{\mathrm{b}}$ \\
\hline NDT \% MS & 57,49 & 57,28 & 59,31 \\
MM \% MS & $10,51^{\mathrm{a}}$ & $9,75^{\mathrm{a}}$ & $7,87^{\mathrm{b}}$ \\
\hline
\end{tabular}

1- Médias seguidas da mesma letra na linha não diferem significativamente pelo teste de Tukey $(\mathrm{P}>0,05)$.

\section{Consumo de forragem}

O consumo de forragem foi avaliado em três épocas do ano: verão, outono e primavera. As datas de cada período de avaliação constam da Tabela 3.

Foram usados 4 bovinos castrados, em crescimento, da raça Nelore para cada parcela. O delineamento foi em blocos ao acaso com 4 repetições. Assim, durante os três períodos foi avaliado o consumo de 144 animais. 
Tabela 3. Datas de avaliação do consumo de forragem de cada período.

\begin{tabular}{lcc}
\hline Período & Início do período & Término do período \\
\hline Verão & $09 / 01 / 2000$ & $14 / 02 / 2000$ \\
Outono & $21 / 03 / 2000$ & $26 / 04 / 2000$ \\
Primavera & $18 / 09 / 2000$ & $24 / 10 / 2000$ \\
\hline
\end{tabular}

Para estimativa da produção de fezes foi usado como marcador externo o óxido de cromo $\left(\mathrm{Cr}_{2} \mathrm{O}_{3}\right)$. Esse foi fornecido na forma de cápsulas intra-ruminal de liberação controlada $\left(65 \% \mathrm{Cr}_{2} \mathrm{O}_{3}\right.$ matrix, Mark II wing desing, CAPTEC New Zealand Ltd).

As cápsulas foram administradas via oral e, após nove dias foi iniciada a coleta das amostras de fezes que prosseguiu por seis dias. As fezes eram coletadas na parte da manhã $(8: 00 \mathrm{~h})$ e durante a tarde $(18: 00 \mathrm{~h})$. Os animais eram levados para o curral e as fezes retiradas diretamente do reto. A escolha de seis dias foi feita em virtude do ciclo de pastejo, onde o período de ocupação de três dias permitia a avaliação do consumo em dois piquetes.

As fezes que foram coletadas durante os seis dias, no final do período foram misturadas e uma sub-amostra foi retirada para a secagem, moagem e determinação da concentração de cromo.

A secagem foi realizada em estufa de ventilação forçada à temperatura de $55^{\circ} \mathrm{C}$ por 72 horas, homogeneizadas e moídas em moinho Wiley em peneira de $1 \mathrm{~mm}$.

A determinação do cromo foi realizada através da técnica de fluorescência de raios $\mathrm{X}$ com dispersão de energia (ED-XRF) conforme a metodologia adotada por Korndörfer (1999).

Em cada período de coleta de fezes alguns animais foram colocados como "branco" para coleta e posterior determinação de cromo, sem que houvesse recebido as 
cápsulas de cromo. Posteriormente as concentrações de cromo foram corrigidas com base na concentração de cromo dos brancos.

Também foi realizado um ensaio de coleta total de fezes com o objetivo de se calcular a recuperação do cromo nas fezes. Foram utilizados dois animais recebendo silagem de "capim", o fornecimento de cromo e dosagem seguiram os mesmos procedimentos já descritos. A recuperação do cromo foi de $96,70 \%$ do total consumido, considerando-se que as cápsulas de cromo liberavam cerca de 1,72 g de $\mathrm{Cr}_{2} \mathrm{O}_{3}$ por dia (segundo o fabricante). Posteriormente as concentrações de cromo foram corrigidas com base em sua taxa de recuperação.

\section{Digestibilidade}

Para a determinação da digestibilidade foi usado a FDN indigestível (FDNi) após 144 horas do material incubado in vitro. As amostras de forragem incubadas foram aquelas representativas de cada tratamento para cada bloco e para cada período, desse modo, foram incubadas 144 amostras de fezes e 36 amostras de forragem. A incubação e posterior determinação da FDNi seguiu a metodologia de Berchieri et al. (2001).

Para o cálculo da produção de fezes e do consumo de MS da forragem, utilizou-se as seguintes fórmulas (Le Du \& Penning, 1982):

$$
\begin{aligned}
& \text { Peso de } \mathrm{Cr}_{2} \mathrm{O}_{3} \text { fornecido (g/dia) } \\
& \begin{array}{l}
\text { Fezes produzidas } \\
(\text { gramas MS/dia) }
\end{array}=\frac{}{\text { Concentração de } \mathrm{Cr}_{2} \mathrm{O}_{3} \text { nas fezes (g/g MS). }} \\
& \text { Ingestão }(\text { gramas MO })=\frac{\text { Peso das fezes }(\text { g MO/dia }) \text { x } 100}{100-\text { digestibilidade MO }}
\end{aligned}
$$

\section{Avaliação dos parâmetros físicos da forragem e manejo da lotação}


Durante 10 ciclos de pastejo, em cada bloco, portanto a cada 9 dias (os blocos eram pastejados em sequência), eram determinados alguns parâmetros relacionados às características físicas da pastagem. Eram levantados a disponibilidade de forragem, o resíduo pós-pastejo e as perdas de forragem durante o pastejo. A forragem disponível foi amostrada e separada em folha, haste, parte morta e parte verde. O mesmo foi feito com o material colhido do resíduo pós-pastejo. Com isso, foi possível o cálculo das diferentes formas de disponibilidade de forragem por área e por animal/dia (Penati $\left.{ }^{4}\right)$.

Diariamente era realizada a medida de altura da forragem nos piquetes que estavam sendo pastejados. A altura da planta foi correlacionada com a oferta de forragem e, a associação altura/oferta de forragem possibilitou determinar a densidade da forragem em $\mathrm{kg} \mathrm{MS} / \mathrm{ha}_{\mathrm{cm}} \mathrm{cm}^{-1}$. A oferta de forragem e o resíduo esperado em cada tratamento eram usados, diariamente, para o cálculo da taxa de lotação animal em cada piquete $\left(\right.$ Penati $\left.^{4}\right)$.

Com a variação da carga animal nos tratamentos foi possível o cálculo da lotação instantânea diária de cada tratamento, bem como a lotação média de cada ciclo de pastejo.

\section{Análise estatística}

Foi realizada análise comparativa entre as médias de consumo de forragem pelos animais, sendo que as diferenças foram testadas através do teste de Tukey ao nível de $5 \%$ de significância.

Posteriormente foi realizada análise de regressão das medidas de consumo com algumas variáveis físicas e nutricionais da forragem. Inicialmente foi feito análise de covariância para cada estação do ano segundo o modelo:

$$
\begin{aligned}
& Y_{i j}=\mu+\beta_{1} I_{i j 1}+\beta_{2} I_{i j 2}+\beta_{3} I_{i j 3}+l_{1} I_{i j 4}+l_{2} I_{i j 5}+\Upsilon\left(X_{i j}-X m e ́ d i a\right)+E_{i j} \text {, onde: } \\
& \left.Y_{i j}=\text { consumo (variável resposta }\right) . \\
& I_{i j}=\text { variáveis indicadoras representando os efeitos de bloco e tratamento. } \\
& X_{i j}-\text { Xmédia = covariável centrada na média. Representa cada uma das }
\end{aligned}
$$
variáveis consideradas como independentes do modelo. 
Este modelo foi analisado separadamente para cada uma das covariáveis. As análises foram realizadas usando-se o pacote estatístico Genstat 5 (Genstat, 1999).

As variáveis que foram usadas nas regressões constam da Tabela 4, além do resíduo pós-pastejo de MS verde (RMV) que consta da Tabela 1. Outras variáveis foram testadas; densidade da forragem, densidade do resíduo, oferta de MS de forragem, teor de lignina/FDN e teor de FDN, porém, como essas não entraram nos melhores modelos, seus valores não são apresentados.

Tabela 4. Média da altura do resíduo pós-pastejo (Alt), oferta de folhas (F), MS digestível (MSD) e FDN digestível (FDND) do capim Tanzânia (Panicum maximum Jacq.) irrigado em três estações do ano (verão, outono e primavera) e sob três resíduos pós-pastejo (T1- Baixo, T2- Médio e T3- Alto).

\begin{tabular}{ccccc}
\hline Estação do ano & T1 & T2 & T3 & Média \\
\hline & & Alt $(\mathrm{cm})$ & \\
Verão & $13,46^{\mathrm{c}}$ & $20,42^{\mathrm{b}}$ & $29,45^{\mathrm{a}}$ & $21,11^{\mathrm{A}}$ \\
Outono & $17,70^{\mathrm{c}}$ & $34,03^{\mathrm{b}}$ & $44,87^{\mathrm{a}}$ & $32,20^{\mathrm{C}}$ \\
Primavera & $17,55^{\mathrm{c}}$ & $27,30^{\mathrm{b}}$ & $39,35^{\mathrm{a}}$ & $28,00^{\mathrm{B}}$ \\
& & $\mathrm{F}\left(\mathrm{kg} \mathrm{MS} / \mathrm{UA} \cdot \mathrm{dia}^{-1}\right)$ & & \\
Verão & $10,66^{\mathrm{c}}$ & $17,20^{\mathrm{b}}$ & $22,81^{\mathrm{a}}$ & 16,89 \\
Outono & $11,59^{\mathrm{c}}$ & $15,41^{\mathrm{b}}$ & $18,71^{\mathrm{a}}$ & 15,24 \\
Primavera & $13,59^{\mathrm{c}}$ & $16,42^{\mathrm{b}}$ & $27,61^{\mathrm{a}}$ & 19,21 \\
& & $\mathrm{MSD}(\% \mathrm{MS})$ & & \\
Verão & $58,72^{\mathrm{a}}$ & $58,81^{\mathrm{a}}$ & $54,72^{\mathrm{a}}$ & $57,42^{\mathrm{A}}$ \\
Outono & $60,10^{\mathrm{a}}$ & $55,48^{\mathrm{b}}$ & $52,34^{\mathrm{b}}$ & $55,97^{\mathrm{AB}}$ \\
Primavera & $54,90^{\mathrm{b}}$ & $52,70^{\mathrm{b}}$ & $52,67^{\mathrm{b}}$ & $53,42^{\mathrm{B}}$ \\
& & FDND $(\% \mathrm{FDN})$ & & \\
Verão & $52,22^{\mathrm{a}}$ & $48,24^{\mathrm{b}}$ & $55,09^{\mathrm{a}}$ & $51,85^{\mathrm{A}}$ \\
Outono & $50,36^{\mathrm{a}}$ & $45,55^{\mathrm{b}}$ & $41,21^{\mathrm{b}}$ & $49,04^{\mathrm{A}}$ \\
Primavera & $47,94^{\mathrm{a}}$ & $42,68^{\mathrm{b}}$ & $38,09^{\mathrm{b}}$ & $42,90^{\mathrm{B}}$ \\
\hline
\end{tabular}

Médias seguidas da mesma letra minúscula na linha ou maiúscula na coluna não diferem significativamente pelo teste de Tukey $(\mathrm{P}>0,05)$.

1- altura considerando os valores zero (quando não havia forragem na tomada das avaliações de produção). 


\subsection{Resultados e Discussão}

A avaliação do consumo de capim Tanzânia não mostrou interação entre tratamento e período. Entretanto, o consumo médio para o tratamento de menor resíduo pós-pastejo (T1) foi menor em comparação aos de maior oferta de forragem (T2 e T3) (Tabela 5). Em média o T1 apresentou consumo de 65,80 g MO/kgPM (g de matéria orgânica por kg de peso metabólico) para os três períodos avaliados (verão, outono e primavera), enquanto que, o consumo em g MO/kgPM para os tratamentos 2 e 3 foi, respectivamente, de 73,61 e 74,20 (Tabela 5).

O consumo de forragem foi menor para a estação da primavera quando comparado aos consumos de verão e outono. Em média, durante a primavera o consumo de capim Tanzânia foi de 61,31 g MO/kgPM, enquanto que, para o período de verão e outono foi, respectivamente, de 77,10 e 75,20 g MO/kgPM (Figura 5).

Tabela 5. Consumo de capim Tanzânia irrigado em g MO.kgPM ${ }^{-1}$ para animais Nelore em crescimento em três estações do ano (verão, outono e primavera) e sob três níveis de resíduo pós-pastejo (T1-Baixo, T2- Médio e T3- Alto).

\begin{tabular}{lcccc}
\hline Período & T1 & T2 & T3 & Média \\
\hline Verão & 68,01 & 80,72 & 80,42 & $77,10^{\mathrm{A}}$ \\
Outono & 71,48 & 78,46 & 76,70 & $75,20^{\mathrm{A}}$ \\
Primavera & 59,38 & 61,02 & 63,28 & $61,31^{\mathrm{B}}$ \\
Média & $65,80^{\mathrm{b}}$ & $73,61^{\mathrm{a}}$ & $74,20^{\mathrm{a}}$ & \\
\hline
\end{tabular}

Médias seguidas da mesma letra maiúscula na coluna ou minúscula na linha não diferem significativamente pelo teste de Tukey $(\mathrm{P}>0,05)$.

Considerando-se os teores de FDN (Tabela 2) e as digestibilidades desse componente da matéria seca do capim Tanzânia (Tabela 4), verifica-se que nessas dietas o consumo de FDN foi entre 1,14 e 1,43\% do peso, seguindo as mesmas tendências apresentadas para o consumo de MO de forragem. Os menores consumos de FDN foram para o tratamento de menor resíduo pós-pastejo e para a primavera. (Tabela 6). 
Tabela 6. Consumo de FDN, de capim Tanzânia irrigado em \% do peso para animais Nelore em crescimento em três estações do ano (verão, outono e primavera) e sob três níveis de resíduo pós-pastejo (T1-Baixo, T2- Médio e T3- Alto).

\begin{tabular}{lcccc}
\hline Estação do ano & T1 & T2 & T3 & Média \\
\hline Verão & 1,21 & 1,43 & 1,43 & $1,36^{\mathrm{A}}$ \\
Outono & 1,22 & 1,45 & 1,45 & $1,37^{\mathrm{A}}$ \\
Primavera & 1,14 & 1,35 & 1,34 & $1,28^{\mathrm{B}}$ \\
Média & $1,19^{\mathrm{b}}$ & $1,41^{\mathrm{a}}$ & $1,41^{\mathrm{a}}$ & 1,34 \\
\hline
\end{tabular}

Médias seguidas da mesma letra maiúscula na coluna ou minúscula na linha não diferem significativamente pelo teste de Tukey $(\mathrm{P}>0,05)$.

Os resultados indicam que o consumo diário de FDN atingiu 1,34 \% do peso animal, sendo superior aos valores de 1,2 \% do peso animal apresentado por Mertens (1994). Os trabalhos de Ruiz et al. (1995) e de Balsalobre (1996) determinaram, para forrageiras tropicais, valores de consumo diário de FDN semelhantes aos obtidos nesta pesquisa para capim Tanzânia irrigado.

A associação do teor de parede celular com o consumo de pastagem tropicais pode não estar correto, pois nesse caso, outras variáveis parecem ser mais importantes na determinação do consumo que o enchimento de rúmen. A correlação do consumo de forragem com parâmetros físicas (oferta de folhas, resíduo pós-pastejo e altura) e nutricionais (digestibilidade da MS e digestibilidade da FDN) da planta, indicam que não foi possível isolar variáveis que pudessem explicar satisfatoriamente o consumo de capim Tanzânia irrigado sob pastejo. Isso mostra que, para a determinação do consumo de plantas forrageiras, outras variáveis não estudadas podem ser tão ou mais importantes quanto os componentes estudados. Entre essas variáveis que influenciam o consumo pode-se citar o efeito das condições climáticas (temperatura, precipitação pluvial, insolação etc.) como decisivos na definição do consumo de forragem.

Para o período de verão foi possível encontrar associações de alguns parâmetros com o consumo de forragem, no entanto, a análise de regressão isolada para as estações do ano, mostram que para o outono e para a primavera o consumo de forragem não pode ser bem explicado por nenhum parâmetro físico ou nutricional. 
O que melhor explicou o consumo de forragem no verão foi a altura do resíduo pós-pastejo (equação 1), seguido pela oferta de forragem em $\mathrm{kg}$ de MS de folhas/UA.dia ${ }^{-1}$ (equação 2) e resíduo de matéria seca verde (equação 3). No entanto, quando se usou o procedimento de regressão múltipla, equação 4 , em que se associa consumo de forragem com altura do resíduo e FDN digestível, o r-quadrado foi maior $(63,33 \%)$.

Em média para as três estações do ano, a altura do resíduo, a oferta de folhas e a MS digestível foram suficientes para explicar cerca de 50\% do consumo de forragem pelos animais (equação 5). Os r-quadrados parciais da equação 5 indicam que a oferta de folhas explica 19,41\% do consumo, a altura do resíduo, 16,07\%, enquanto que a MSD explica $15,02 \%$ do consumo.

$$
\begin{aligned}
& \mathrm{IMO}(\mathrm{g} \mathrm{MO} / \mathrm{kg} \mathrm{PM})=-0,028 * \mathrm{Alt}^{2}+2,19 * \mathrm{Alt}+44,99 \\
& \mathrm{R}^{2}=53,96 \\
& \mathrm{IMO}(\mathrm{g} \mathrm{MO} / \mathrm{kg} \mathrm{PM})=-0,008 * \mathrm{~F}^{2}+1,07 * \mathrm{~F}+53,80 \\
& \mathrm{R}^{2}=42,51 \\
& \mathrm{IMO}(\mathrm{g} \mathrm{MO} / \mathrm{kg} \mathrm{PM})=-0,000006 * \mathrm{RMV}^{2}+0,034 * \mathrm{RMV}+34,81 \quad \text { (equação 5.3) } \\
& \mathrm{R}^{2}=33,51 \\
& \mathrm{IMO}(\mathrm{g} \mathrm{MO} / \mathrm{kg} \mathrm{PM})=149,73+1,10 * \text { Alt }-1,89 \text { FDND } \\
& R^{2}=63,33 \\
& \mathrm{R}^{2}=50,50
\end{aligned}
$$

Onde: Alt - altura do resíduo pós-pastejo em $\mathrm{cm}$ medido com a trena. F - oferta de folhas em kg MS/UA.dia ${ }^{-1}$. MSD - teor de matéria seca digestível em \% da MS. FDND - FDN digestível em \% da FDN. 
RMV - resíduo pós-pastejo em $\mathrm{kg} \mathrm{MSV/ha.}$

MSV - matéria seca verde

Os parâmetros físicos da planta (oferta de folhas, resíduo pós-pastejo e altura do resíduo) parecem causar maior interferência no consumo de animais sob pastejo que os aspectos de qualidade da forragem (FDND e MSD) (equações 5.1, 5.2, 5.3, 5.4 5.5). Por outro lado, como já comentado anteriormente, os parâmetros físicos não foram suficientes para explicar satisfatoriamente o consumo de forragem. Diante disso, tem-se a necessidade de estudos mais detalhados dos aspectos de consumo de animais sob pastejo, onde provavelmente os estudos de comportamento animal poderão auxiliar no seu entendimento, como indicam os trabalhos de Carvalho et al. (2001) e de Costa et al. (2001).

As Figuras 1 e 2 mostram que o consumo de forragem aumenta conforme aumenta a altura do resíduo pós-pastejo e a oferta de folhas/UA. Em relação à massa de resíduo pós-pastejo (Figura 3), o consumo também é maior para os maiores valores, no entanto é possível indicar que a partir de $2833 \mathrm{~kg}$ de MS verde/ha não há mais aumento de consumo de forragem, nesse ponto o consumo seria de 82,98 g/kgPM.

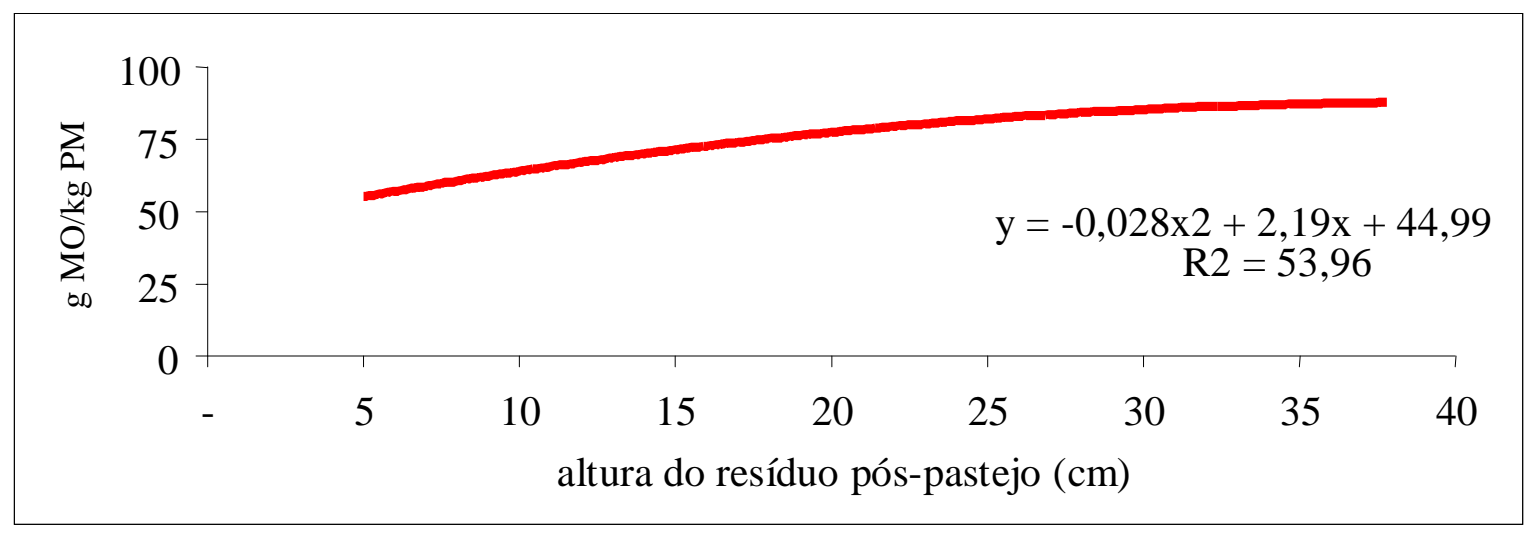

Figura 1 - Consumo de capim Tanzânia (Panicum maximum Jacq.) irrigado no período de verão sob três níveis de resíduo pós-pastejo (Baixo, Médio e Alto) em função da altura do resíduo pós-pastejo. 


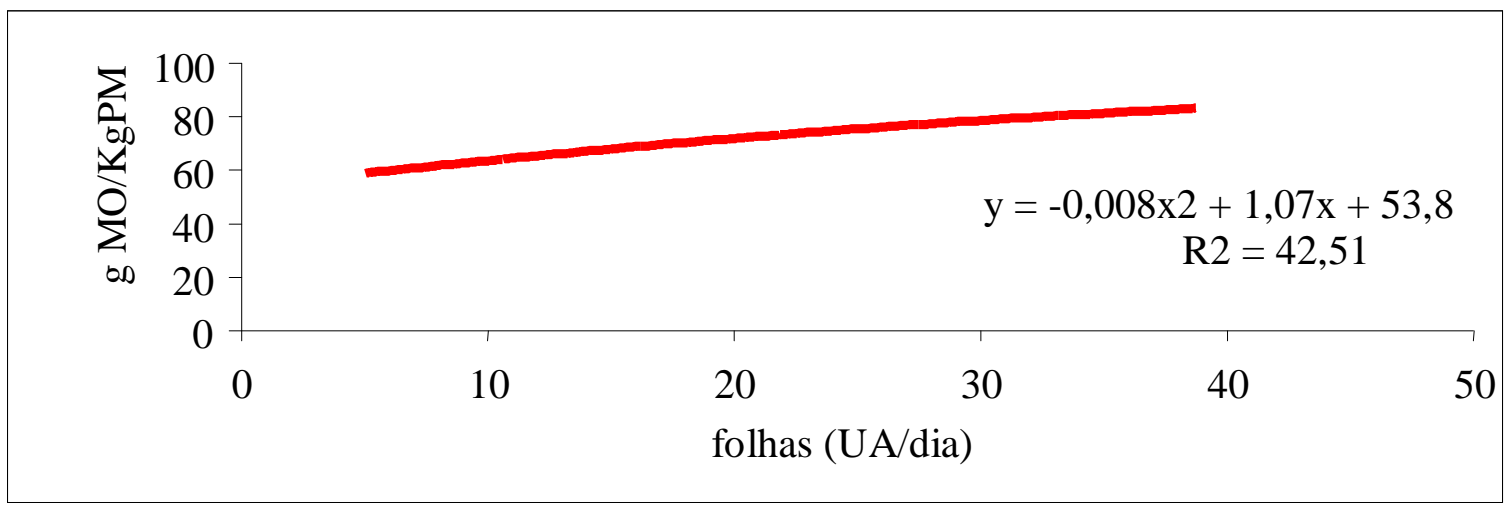

Figura 2 - Consumo do capim Tanzânia (Panicum maximum Jacq.) irrigado no período de verão sob três níveis de resíduo pós-pastejo (Baixo, Médio e Alto) em função da oferta de folhas.

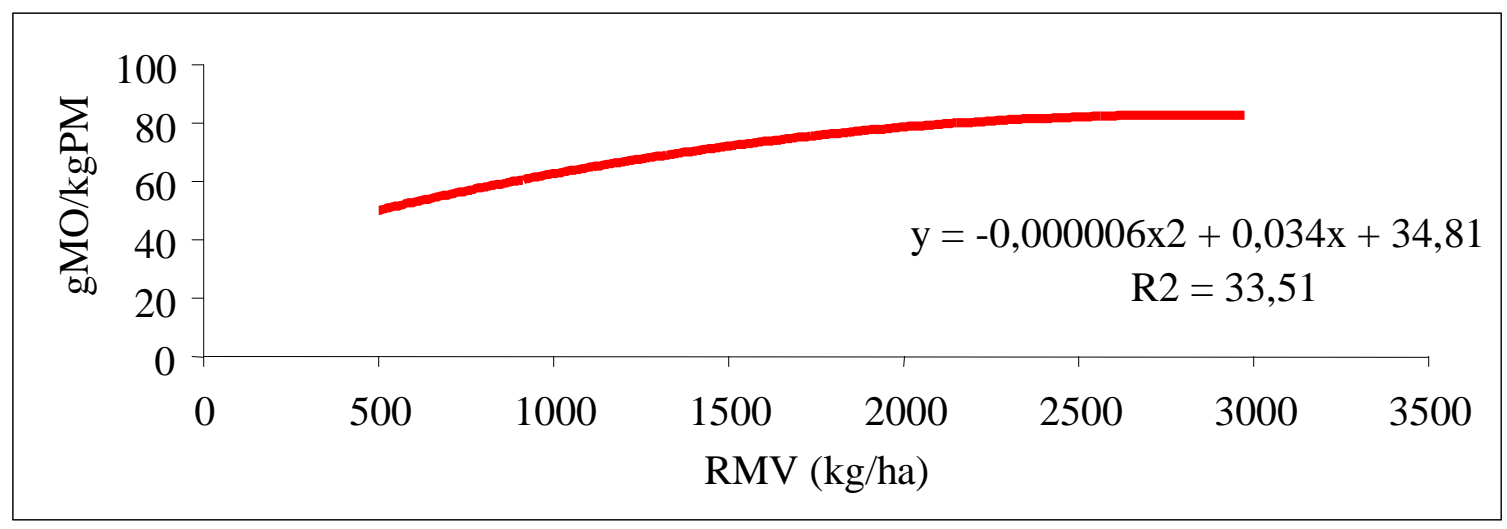

Figura 3 - Consumo do capim Tanzânia (Panicum maximum Jacq.) irrigado no período de verão sob três níveis de resíduo pós-pastejo (Baixo, Médio e Alto) em função do resíduo de matéria seca verde pós-pastejo (RMV).

A Tabela 7 apresenta o consumo de proteína degradável no rúmen (PDR) e o consumo de MO degradável no rúmen (MODR), assim como, a relação de PDR/MODR. Observa-se que o consumo de PDR está além do recomendado pela literatura em relação à MODR, a média da relação PDR/MODR encontrada nesse trabalho está ao redor de $16,8 \%$, onde o menor valor foi para o T1 no outono $(15,02 \%)$ e o maior para o T2 na primavera (19,18\%). Sendo o dado de literatura de 13\% de PDR/MODR (NRC, 1990; Poppi \& McLennan, 1995) para que se tenha a adequada sincronização de energia e 
proteína no rúmen, pode se dizer que mesmo a menor relação (T1, outono) está acima desse valor, o que pode significar excesso de PDR ou falta de energia no rúmen.

Tabela 7. Consumo de proteína degradável no rúmen (PDR) e matéria orgânica degradável no rúmen (MODR) e suas relações para as dietas correspondentes de capim Tanzânia irrigado sob três níveis de resíduo pós-pastejo (T1- Baixo; T2Médio; T3- Alto) em três estações do ano (verão, outono e primavera) considerando animais de $300 \mathrm{~kg}$.

\begin{tabular}{lccccccccc}
\hline Parâmetros & T1 & $\begin{array}{c}\text { T2 } \\
\text { Verão }\end{array}$ & T3 & T1 & T2 & T3 & T1 & T2 & T3 \\
& & & & Outono & & & Primavera \\
& & & & & & & & \\
\hline Consumo (kg MO) & 4,90 & 5,82 & 5,80 & 5,15 & 5,66 & 5,53 & 4,28 & 4,40 & 4,56 \\
PB (\% MO) & & 13,15 & & & 12,64 & & & 15,86 & \\
MOD (\% MO) & 65,62 & 60,74 & 61,15 & 61,10 & 57,65 & 57,99 & 59,85 & 56,20 & 57,17 \\
PDR (\% MO) & 11,00 & 10,18 & 10,37 & 9,18 & 9,12 & 9,36 & 10,51 & 10,78 & 9,99 \\
Consumo PDR (g) & 539 & 592 & 601 & 473 & 516 & 518 & 450 & 474 & 456 \\
Consumo MOD (kg) & 3217 & 3534 & 3545 & 3147 & 3263 & 3207 & 2560 & 2473 & 2607 \\
Relação PDR/MOD (\%) & 16,76 & 16,76 & 16,95 & 15,02 & 15,83 & 16,15 & 17,55 & 19,18 & 17,48 \\
\hline
\end{tabular}

O excesso de PDR nessas forragens é ratificado pela análise das dietas obtidas pelo uso do programa de Cornell. A Tabela 8 apresenta alguns parâmetros de desempenho animal associado à características das dietas obtidas a partir do consumo real de forragem avaliado neste trabalho.

Nota-se que há excedente de N ruminal entre 4 e $29 \%$, o que significa entre 3,60 e 22,40 g de $\mathrm{N}$ diário em excesso no rúmen. Esse excesso de $\mathrm{N}$ provoca um gasto de energia pelo organismo (custo uréia), que tem por objetivo metabolizar e excretar o $\mathrm{N}$ não utilizado no rúmen. No entanto, essa energia gasta é retirada da energia que seria usada para ganho de peso, como nesse caso o ganho de peso é limitado pela falta de energia metabólica (EM), o custo uréia provoca redução de ganho de peso. 
Tabela 8. Avaliação das dietas através do programa de Cornell considerando os resultados das amostras do pastejo simulado de capim Tanzânia (Panicum maximum Jacq.) irrigado em três níveis de resíduo pós-pastejo (T1- Baixo; T2- Médio; T3- Alto) e em três estações do ano (verão, outono e primavera).

\begin{tabular}{|c|c|c|c|c|c|c|c|c|c|}
\hline Parâmetros & $\mathrm{T} 1$ & $\begin{array}{c}\mathrm{T} 2 \\
\text { verão }\end{array}$ & T3 & $\mathrm{T} 1$ & $\begin{array}{c}\mathrm{T} 2 \\
\text { Outono }\end{array}$ & T3 & $\mathrm{T} 1$ & $\begin{array}{c}\mathrm{T} 2 \\
\text { rimave }\end{array}$ & T3 \\
\hline $\mathrm{GP}^{\mathrm{EM}}(\mathrm{kg})^{1}$ & 0,29 & 0,44 & 0,44 & 0,29 & 0,37 & 0,35 & 0,14 & 0,16 & 0,19 \\
\hline GP PM $(\mathrm{kg})^{2}$ & 0,50 & 0,64 & 0,64 & 0,57 & 0,65 & 0,63 & 0,43 & 0,45 & 0,48 \\
\hline $\begin{array}{l}\text { Custo uréia } \\
\text { (Mcal/dia) }\end{array}$ & 0,16 & 0,15 & 0,15 & 0,20 & 0,20 & 0,20 & 0,27 & 0,27 & 0,26 \\
\hline $\mathrm{N}$ ruminal (g/dia) & 7,60 & 9,60 & 9,50 & 3,60 & 4,20 & 4,10 & 21,10 & 21,60 & 22,40 \\
\hline $\begin{array}{l}\mathrm{N} \text { ruminal } \\
\text { (\% do adequado) }\end{array}$ & 108 & 109 & 104 & 104 & 104 & 104 & 129 & 129 & 129 \\
\hline NDT estimado & 57,40 & 56,60 & 56,60 & 56,00 & 55,60 & 55,70 & 57,60 & 57,50 & 57,30 \\
\hline $\begin{array}{l}\text { Consumo estimado } \\
(\% \text { PV MS) }\end{array}$ & 2,44 & 2,44 & 2,44 & 2,43 & 2,43 & 2,43 & 2,45 & 2,45 & 2,45 \\
\hline $\begin{array}{l}\text { Consumo real }^{4} \\
(\% \text { PV MS) }\end{array}$ & 1,97 & 2,34 & 2,35 & 2,06 & 2,18 & 2,09 & 1,58 & 1,60 & 1,69 \\
\hline $\begin{array}{l}\text { Consumo estimado } \\
\text { (\% do real) }\end{array}$ & 80,74 & 95,90 & 96,31 & 84,77 & 89,71 & 86,01 & 64,49 & 65,31 & 68,98 \\
\hline
\end{tabular}

Os dados obtidos no programa de Cornell são relativos à uma animal em crescimento de $300 \mathrm{~kg}$ da raça Nelore castrado, com escore de condição corporal 5, sem implante e sem ionóforo, atingindo peso de abate com $510 \mathrm{~kg}$ com $27 \%$ de gordura. As condições climáticas foram ajustadas para que não fossem limitantes para o desempenho animal.

${ }^{1-}$ Ganho de peso para a energia metabólica consumida

${ }^{2-}$ Ganho de peso para a proteína metabólica consumida.

${ }^{3-}$ Consumo estimado pelo programa de Cornell

${ }^{4-}$ Consumo avaliado no trabalho 
O consumo estimado pelo programa de Cornell não leva em consideração as características físicas da planta (oferta de forragem, resíduo pós-pastejo, altura etc.), isso faz com que determine consumos idênticos para os três tratamentos. A semelhança no consumo de forragem determinado pelo programa de Cornell se justifica pelo fato de considerar somente a qualidade da forragem como variável para determinar o consumo e, neste trabalho, não houve diferenças entre os tratamentos quanto a qualidade da forragem. Pode-se concluir que o programa de Cornell superestimou o consumo de forragem do capim Tanzânia entre 3,80 e 55\% do consumo real obtido.

Por outro lado Kolver et al. (1998) avaliaram 25 dietas de vacas em lactação sob pastejo em plantas forrageiras de clima temperado. Observaram que o programa de Cornell subestimou o consumo em 13\%, contrariando o que ocorreu no atual trabalho. No entanto, a equação de estimativa de consumo utilizada pelo programa não leva em consideração a cinética ruminal, assim, é de se esperar superestimativas de consumo em pastagens de menor taxa de degradação ruminal, uma vez que apresentam menor taxa de passagem pelo trato digestivo.

O ganho de peso observado na avaliação do programa de Cornell foi maior para a proteína metabólica (PM), sendo que a energia metabólica (EM) foi limitante no desempenho animal. Entretanto, os valores de ganho de peso estimados através da PM pelo programa, subestimaram os valores de ganho de peso de acordo com os ganhos obtidos por Penati ${ }^{4}$. Neste estudo Penati ${ }^{4}$ obteve para os tratamentos de menor resíduo pós-pastejo ganhos na ordem de 468, 552 e 352 g/animal.dia ${ }^{-1}$, respectivamente para verão, outono e inverno. No tratamento intermediário (T2), os ganhos observados para verão, outono e primavera foram, respectivamente de, 596, 627 e 343 g/animal.dia ${ }^{-1}$, os ganhos para o T3 foram de 692 para o verão, 708 para o outono e de 293 g/animal.dia ${ }^{-1}$ para a primavera.

Pode se concluir que o programa de Cornell estima de forma aceitável o NDT da forragem comparado a estimativa obtida através da equação de Weiss (1993). Em média a estimativa do programa de Cornell (Tabela 8) para o NDT foi de 56,87; 55,77 e 57,46 respectivamente para o verão, outono e primavera, valores esses 0,$62 ; 1,51$ e 1,85 pontos percentuais acima do estimado pela equação de Weiss (1993). 
Com a avaliação das dietas pelo programa de Cornell é possível simular o efeito da suplementação concentrada para cada dieta. Assim foram adotas três suplementações: $70 \mathrm{~g}$ de uréia/animal.dia ${ }^{-1} ; 500 \mathrm{~g}$ de milho/animal.dia ${ }^{-1}$ ou $300 \mathrm{~g}$ de farelo de algodão/animal.dia ${ }^{-1}$. Os mesmos animais Nelore em crescimento de $300 \mathrm{~kg}$ de peso foram adotados, assim como e as condições climáticas as mesmas da simulação anterior.

Na Tabela 9 é possível observar que nessa situação a suplementação com uréia não deve ser adotada pois, já existe $\mathrm{N}$ ruminal em excesso, que determina redução de desempenho animal devido ao aumento do custo uréia. Por outro lado, apesar de haver excesso de $\mathrm{N}$, a adição de uma fonte protéica de melhor qualidade como o farelo de algodão $38 \%$ promoverá aumento de desempenho tanto em relação à PM quanto em relação à EM.

Tabela 9. Efeito da suplementação com uréia, milho ou farelo de algodão $38 \%$ no desempenho de animais Nelore de $300 \mathrm{~kg}$ em crescimento através do programa de Cornell para as dietas representativas de capim Tanzânia (Panicum maximum Jacq.) irrigado sob três níveis de resíduo pós-pastejo (T1- Baixo; T2- Médio; T3- Alto) em três estações do ano (verão, outono e primavera).

\begin{tabular}{|c|c|c|c|c|c|c|c|c|c|}
\hline Parâmetros & $\mathrm{T} 1$ & $\begin{array}{c}\text { T2 } \\
\text { Verão }\end{array}$ & $\mathrm{T} 3$ & \multicolumn{3}{|c|}{ Outono } & \multicolumn{2}{|c|}{ Primavera } & T3 \\
\hline \multicolumn{10}{|c|}{ Uréia $\left(70 \mathrm{~g} /\right.$ cabeça.dia $\left.^{-1}\right)$} \\
\hline GP EM $(\mathrm{kg})^{1}$ & 0,28 & 0,43 & 0,43 & 0,28 & 0,36 & 0,34 & 0,14 & 0,16 & 0,19 \\
\hline $\operatorname{GP}$ PM $(\mathrm{kg})^{2}$ & 0,50 & 0,64 & 0,64 & 0,57 & 0,65 & 0,63 & 0,43 & 0,45 & 0,48 \\
\hline \multicolumn{10}{|c|}{ Milho (500 g/cabeça.dia $\left.{ }^{-1}\right)$} \\
\hline GP EM (kg) & 0,48 & 0,63 & 0,63 & 0,48 & 0,55 & 0,53 & 0,34 & 0,36 & 0,39 \\
\hline GP PM (kg) & 0,68 & 0,82 & 0,82 & 0,75 & 0,84 & 0,82 & 0,61 & 0,63 & 0,66 \\
\hline \multicolumn{10}{|c|}{ Farelo de algodão $38 \%$ (300 g/cabeça.dia ${ }^{-1}$ ) } \\
\hline GP EM (kg) & 0,37 & 0,52 & 0,52 & 0,37 & 0,44 & 0,42 & 0,23 & 0,25 & 0,28 \\
\hline GP PM (kg) & 0,64 & 0,79 & 0,78 & 0,71 & 0,80 & 0,77 & 0,56 & 0,58 & 0,61 \\
\hline
\end{tabular}


Entretanto, como a suplementação energética deverá promover melhor equilíbrio entre energia e proteína no rúmen, observa-se que as estimativas dos efeitos da suplementação dos animais em pastagens irrigadas de capim Tanzânia com a adição de $500 \mathrm{~g}$ de milho possibilitaria maiores aumentos no desempenho dos animais. Porém, os suplementos energéticos podem provocar efeito de substituição da forragem, que provoca redução de consumo e conseqüente alterações no desempenho animal. Por outro lado, o suplemento protéico (farelo de algodão), que resultou em ganhos menores do que a suplementação energética poderia aumentar o consumo de forragem. No entanto, os efeitos de substituição e adição não foram considerados para essa simulação.

\subsection{Conclusões}

Não houve interação entre estações do ano e as intensidades de pastejos, representados pelos diferentes resíduos pós-pastejo para a avaliação do consumo de MS. O tratamento de menor resíduo apresentou o menor consumo, assim como na primavera os consumos foram menores que para verão e outono.

Em média o consumo de FDN foi de $1,34 \%$ do peso animal.

Em média para as três estações do ano a altura do resíduo pós-pastejo, a oferta de folhas e a MSD explicaram 50\% do consumo de forragem.

No verão com resíduo de matéria seca verde de $2833 \mathrm{~kg} / \mathrm{ha}$ se atinge o consumo máximo de forragem.

Em média a PDR/MODR foi de $16,81 \%$ gerando um excesso de $\mathrm{N}$ ruminal entre 4 e $29 \%$.

O programa de Cornell superestimou o consumo de matéria seca entre 3,80 e 55\%. A melhor suplementação para as dietas de pastagens de capim Tanzânia irrigado ao longo do ano parece ser de $500 \mathrm{~g}$ de milho comparado à $70 \mathrm{~g}$ de uréia ou $300 \mathrm{~g}$ de farelo de algodão $38 \%$. 


\section{CONCLUSÕES}

Não houve diferenças de qualidade nutricional entre os tratamentos ao longo dos ciclos de pastejos para nenhum dos parâmetros avaliados.

As menores qualidades da forragem, evidenciadas pelos menores teores de NDT e maiores proporções da fração $\mathrm{C}$ dos carboidratos, foram verificadas nos ciclos de pastejos correspondentes aos meses de julho a setembro.

A menor qualidade nos meses de julho a setembro pode estar relacionado a menor renovação de tecidos durante o período de inverno e a um provável acúmulo de perfilhos florescidos desde o mês de abril.

Os teores de proteína podem ser considerados altos e tiveram tendência de aumento com o avanço dos ciclos de pastejos, isso pode ser justificado pelas adubações nitrogenadas nos pastejos de inverno, o que promoveu consumo de luxo de $\mathrm{N}$, havendo acumulo, principalmente na forma de $\mathrm{NnP}$.

A maior proporção do $\mathrm{N}$ se encontra na parede celular, aproximadamente $50 \%$, correspondendo à $40 \%$ da fração B3 da proteína. Isso indica que essa fração deve ter prioridade de estudos no tocante a cinética de degradação ruminal, para uma melhor caracterização da proteína das plantas do capim Tanzânia.

Em relação à degradação ruminal da MS, FDN e da proteína, o período de verão (dezembro e janeiro) apresentou a melhor qualidade da forragem quando comparada com as forragens amostradas em abril (outono) e outubro (primavera).

Houve tendências para o tratamento de menor resíduo pós-pastejo (T1) apresentar melhor qualidade no verão, no entanto do verão para a primavera foi o tratamento que apresentou maior redução de digestibilidade. 
Para o T3 a redução na digestibilidade da FDN, do verão para a primavera, foi em maior proporção que para a MS, quando comparada aos outros tratamentos (T1 e $\mathrm{T} 2$ ).

A fração prontamente solúvel da proteína pode ser maior que $40 \%$ da PDR. A PDR variou entre 76,36 e 62,05\% PB.

A fração C da FDN é maior que a fração C calculada pelo método adotado pelo programa de Cornell, indicando que o fator de multiplicação da FDN deve ser maior que 2,4, sugerindo que esse valor deveria estar entre 2,91 e 3,35.

A fração $\mathrm{C}$ do nFDN é maior que a calculada em laboratório como sendo nFDA, isso indica erros na determinação do nFDA.

Não há um parâmetro de qualidade nutricional que justifique adequadamente a cinética ruminal, tanto para MS, FDN, FDA, PB e nFDN. A degradação da proteína é bem explicada pelos teores de PB e de suas frações. Quanto maior o teor de PB e de nFDN, pior foi a digestibilidade da PB.

Não houve interação entre as estações do ano (verão, outono e primavera) e as intensidades de pastejos (representadas pelos diferentes resíduos pós-pastejo) para a avaliação do consumo de MS. O tratamento de menor resíduo apresentou o menor consumo, assim como na primavera os consumos foram menores que para verão e outono.

Em média o consumo de FDN foi de 1,34\% do peso animal.

Em média para as três estações do ano a altura do resíduo pós-pastejo, a oferta de folhas e a MSD explicaram 50\% do consumo de forragem. No período de verão, com o aumento da altura de pastejo e da oferta de folhas/UA, houve aumento no consumo de forragem. Para as estações de outono e primavera, não foi possível identificar um único parâmetro (físico ou químico) que pudesse explicar satisfatoriamente o consumo de forragem.

No verão com resíduo de matéria seca verde de $2833 \mathrm{~kg} / \mathrm{ha}$ se atinge o consumo máximo de forragem.

Em média a PDR/MODR foi de $16,81 \%$ gerando um excesso de $\mathrm{N}$ ruminal entre 4 e $29 \%$. 
O programa de Cornell superestimou o consumo de matéria seca entre 3,80 e 55\%. A melhor suplementação para as dietas de pastagens de capim Tanzânia irrigado ao longo do ano parece ser de $500 \mathrm{~g}$ de milho comparado à $70 \mathrm{~g}$ de uréia ou $300 \mathrm{~g}$ de farelo de algodão $38 \%$. 


\section{REFERÊNCIAS BIBLIOGRÁFICAS}

AGUIAR, S.V.H.; BALSALOBRE, M.A.A.; LABONIA, V.D. de; SANTOS, P.M.; CORSI, M. Proporção de partes morfológicas do capim Tanzânia (Panicum maximum Jacq.) em três intensidades de pastejo ao longo do ano. In: REUNIÃO ANUAL DA SOCIEDADE BRASILEIRA DE ZOOTECNIA, 38., Piracicaba, 2001. Anais. Piracicaba: SBZ, 2001. p.342-343.

ALMEIDA, E.X. de; MARASCHIN, G.E.; HARTHMANN, D.E.L.; RIBEIRO FILHO, H.M.N.; SETELICH, E.A. Oferta de forragem de capim-elefante anão 'Mott' e o rendimento animal. Revista da Sociedade Brasileira de Zootecnia, v.29, n.5, p.1288-1295, 2000.

AGRICULTURE AND FOOD RESEARCH COUNCIL. Technical committee on responses to nutrients: report number 9 , nutritive requerements of ruminant animals: protein. Nutrition Abstracts and Reviews (Series B), v.62, n.12, p.787 - 835, 1992.

AGRICULTURE RESEARCH COUCIL. The nutrient requerements of ruminant livestock, suplement 1 - protein. Slough: Commonwealth Agricultural Bureaux, England, 1985. 283p. 
BALSALOBRE, M.A.A. Desempenho de vacas em lactação sob pastejo rotacionado de Capim-elefante (Pennisetum purpureum Schum.). Piracicaba, 1996, 139p. Dissertação (Mestrado) - Escola Superior de Agricultura "Luiz de Queiroz", Universidade de São Paulo.

BARROS, C.O.; PINTO, J.C.; EVANGELISTA, A.R.; MUNIZ, J.A.; ANDRADE, I.F. de; SANTOS, I.P.A. dos. Rendimento e composição química do capim Tanzânia estabelecido com milheto, sob três doses de nitrogênio(compact disc). In: REUNIÃO ANUAL DA SOCIEDADE BRASILEIRA DE ZOOTECNIA, 37., Viçosa, 2000. Anais. Viçosa: SBZ, 2000.

BERCHIELlI, T.T.; SADER, A.P.O.; TONANI, F.L.; PAZIANI, S.F.; ANDRADE, P. Avaliação da determinação da fibra em detergente neutro e da fibra em detergente ácido pelo sistema ANKON. Revista Brasileira de Zootecnia, v.30, p.1572-1578, 2001.

BERZAGHI, P.; COZZI, G.; ANDRIGHETTO, I. The use of near infrared analysis for in situ studies. Journal of Dairy Science, v.80, p.3263 - 3270, 1997.

BRIEN, C. Sets of latin squares. In: BRIEN C. The design \& mixed-model analysis of experiments. http://linus.levels.unisa.edu.au/ matcjb/research/dammnotes.html, (20 Nov. 2001).

BURLISON, A. J.; HODGSON, J.; ILLIUS, A. W. Sward canopy structure and the bite dimension and bite weight of grazing sheep. Grass and Forage Science, v.46, p.2938, 1991.

CABAllERO, R.; ALZUETA, C.; ORTIZ, L.T.; RODRÍGUEZ, M.L.; BARRO, C.; REBOLÉ, A. Carbohydrate and protein fractions of fresh and dried Common Vetch at three maturity stages. Agronomy Journal, v.93, p.1006-1013, 2001. 
CARNEVALLI, R.A.; SILVA, S.C. da; PEDREIRA, C.G.S.; FAGUNDES, J.L.; CARVALHO, C.A.B. de; SBIRISSIA, A.F.; PINTO, L.F.M.; UEBELE, M.C.; PASSANEZI, M.M. Pasture and animal responses of Tifton-85 swards grazed by sheep under continuous stocking. In: SIMPÓSIO INTERNACIONAL "GRASSLAND ECOPHYSIOLOGY AND GRAZING ECOLOGY", 1., Curitiba, 1999, Anais. Curitiba: UFPR, 1999. p.357-361.

CARVALHO, P.C.F.; RIBEIRO, H.M.N.F., POLI, C.H.E.; DELAGARDE, R. Importância da estrutura da pastagem na ingestão e seleção de dietas pelo animal em pastejo. In: REUNIÃO ANUAL DA SOCIEDADE BRASILEIRA DE ZOOTECNIA, 38., Piracicaba, 2001. Anais. Piracicaba:SBZ, 2001. p.853-871.

CILLIERS, J.W.; VAN BILJON, P.L.; TOLMAY, E.; COERTZE, C. Effects of different levels of fertilizer apllication to veld on growth of steers and chemical composition of the herbage. Grass and Forage Science, v.52, n.3, p.242 - 248, 1997.

CLARK, J.H.; KLUSMEYER, T.H.; CAMERON, M.R. Microbial protein synthesis and flows of nitrogen fractions to the duodenum of dairy cows. Jounal of Dairy Science, v.75, p.2304 - 2320, 1992.

COMBELLAS, J.; HODGSON, J. Herbage intake and milk production by grazing dairy cows 1 . The effect of variation in herbage mass and daily herbage allowance in a short - term trial. Grass and Forage Science, v.34, p.209-214, 1979. 
COSTA, R.Z.M. da; YABUTA, F.H.; BALSALOBRE, M.A.A.; SANTOS, P.M.; CORSI, M. Comportamento ingestivo de maCTs castrados da raça neloreutilizados em pastagem irrigada de Panicum maximum cv. Tanzânia sob pastejo rotacionado com diferentes níveis de resíduo pós-pastejo. In: REUNIÃO ANUAL DA SOCIEDADE BRASILEIRA DE ZOOTECNIA, 38., Piracicaba, 2001. Anais. Piracicaba:SBZ, 2001. p.228-230.

COZZOLINO, D.; ACOSTA, Y.; GARCIA, J. Application of near infrared reflectance spectroscopy (NIRS) to forage evaluation in Uruguay. In: INTERNATIONAL GRASSLAND CONGRESS, 19., São Pedro, 2001. Proceedings, Piracicaba: FEALQ, 2001. p.370.

DECHAMPS, F.C. Implicações do período de crescimento na composição química e digestão dos tecidos de cultivares de capim elefante. Revista Brasileira de Zootecnia, v.28, n.6, p.1178-1189, 1999.

FELIPPE, G.M. Effects of photoperiod, $\mathrm{GA}_{3}$ and $\mathrm{CCC}$ on flowering of Panicum maximum. Hoehnea, v.7, p.11-16, 1978.

FOX, D.G.; SNIFFEN, C.J.; O’CONNOR, J.D.; RUSSEL, J.B.; VAN SOEST, P.J. A net carbohydrate and protein system for evaluating cattle diets: III. Cattle requirements and diet adequacy. Journal of Animal Science, v.70, p.3578 - 3596, 1992.

FRITZ, J.O.; MOORE, K.J.; JASTER, E.H. Digestion kinetics and cell wall composition of Brown Midrib Sorghum x Sudan grass morphological components. Crop Science, v.30, p.213-219, 1990.

GENSTAT 5 Release 4.1 Reference Manual: Genstat 5 Committee. Harpender: Numerical Algoritms Group, 1999. 782p. 
GLENN, B.P.; ELY, D.G.; GLENN, S.; DOUGLASS, L.W.; BULL, L.S.; BUSH, L.P. Effects of ammonium nitrate and potassium sulfate fertilization on rates of ruminal in situ disappearance of Tall Fescue and Orchardgrass nitrogen and sulfur. Canadian Journal of Animal Science, v.65, p.631 - 645, 1985.

GOERING, H.K.; VAN SOEST, P.J. Forage fiber analyses (apparatus, reagents, procedures, and some applications). Washington: ARS-USDA, 1970. 19p. (Agricultural Handbook, 379).

GRANT, R.J. e MERTENS, D.R. Influence of buffer $\mathrm{pH}$ and raw corn starch addition on in vitro fiber digestion kinetics. Journal of Dairy Science, v.75, p.2762 - 2768, 1992.

HALIM, R.A.; BUXTON, D.R.; HATTENDORF, M.J.; CARLSON, R.E. Water stress effects on alfalfa forage quality after adjustment for maturity differences. Agronomy Journal, v.81, p.189 - 194, 1989.

HILLENSHEIM, A. Fatores que afetam o consumo e perdas de capim elefante (Pennisetum purpureum, Schum.) sob pastejo. Piracicaba, 1988. 94p. Dissertação (Mestrado) - Escola Superior de Agricultura “Luiz de Queiroz”, Universidade de São Paulo.

HELDT, J.S.; COCHRAN, R.C.; MATHIS, C.P.; WOODS, B.C.; OLSON, K.C.; TITGEMEYER, E.C.; NAGARAJA, T.G.; VAZANTI, E.S.; JOHNSON, D.E. Effects of level and source of carbohydrate and level of degradable intake protein on intake and digestion of low-quality tallgrass-prairie hay by beefs steers. Journal of Animal Science, v.77, p.2846-2854, 1999. 
HODGSON, J.; CLARK, D.A.; MITCHELL, R.J. Foraging behavior in grazing animals and its impact on plant communities. In: FAHEY, G.C. JR.; COLLINS, M.; MERTENS, D.R.; MOSER, L.E. (Ed.) Forage quality, evaluation and utilization. Madison: ASA; CSSA; SSSA, 1994. cap.19, p.796 - 827.

HOLMES, C.W.; WILSON, G.F. Milk production from pasture. New Zeland: Butterworths, 1984. 319p.

HOPKINS, W.G. Introduction to plant physiology. New York: John Wiley, 1995. 464p.

HOPKINSON, J.M.; ENGLISH, B.H. Spikelet population dynamics in seed crops of Panicum maximum 'Gatton'. Seed Science and Technology, v.10, p.379-403, 1982.

KOLVER E.S.; MULLER, L.D.; BARRY, M.C.; PENNO, J.W. Evoluation and application of the Cornell Net Carbohydrate and Protein System for dairy cows fed diets based on pasture. Journal of Dairy Science., v.81, p.2029-2039, 1998.

KORNDÖRFER, C.M. Eficiência de utilização do feno de Brachiaria decumbens na alimentação de ovinos Santa Inês. Piracicaba, 1999. 110p. Tese (Doutorado) Escola Superio de Agricultura "Luiz de Queiroz”, Universidade de São Paulo.

KRISHNAMOORTHY, U.C.; MUSCATO, T.V.; SNIFFEN, C.J.; VAN SOEST, P.J. Nitrogen fractions in selected feedstuffs. Journal of Dairy Science, v.65, p.217, 1982.

LACA, E.A.; DEMMENT, M.W.; DISTEL, R.A.; GRIGGS, T.C. A conceptual model to explain variation in ingestive behaviour within a feeding patch. In: INTERNATIONAL GRASSLAND CONGRESS, 17., Queensland, 1993. Proceedings. Queensland: Massey University, 1993. p.710 - 712. 
LANNA, D.P.D.; FOX, D.G.; BALSALOBRE, M.A.A.; CORSI, M.; TRAXLER, M. Utilização da metodologia de análises de alimentos do CNCPS e do sistema de produção de gas in vitro na estimativa do valor nutricional do capim elefante. In: REUNIÃO ANUAL DA SOCIEDADE BRASILEIRA DE ZOOTECNIA, 34., Fortaleza, 1996. Anais. Fortaleza: SBZ, 1996. p.289- 291.

LE DU, Y.L.P.; PENNING, P.D. Animal based techniques for estimating herbage intake. In: LEAVER, J.D. (Ed.). Herbage intake handbook. Berkshire: British Grassland Society, 1982. cap.3, p.37-76.

LICITRA, G.; HERNANDEZ, T.M.; VAN SOEST, P.J. Standardization of procedures for nitrogen fractionation of ruminant feeds. Animal Feed Science Technology, v.57, p.347 - 358, 1996.

LIMA, G.F.C.; SOLLENBERGER, L.E.; MOORE, J.E.; KUNKLE, W.E. Concentração e fracionamento do nitrogênio em gramíneas forrageiras tropicais e subtropicais (compact disc). In: REUNIÃO ANUAL DA SOCIEDADE BRASILEIRA DE ZOOTECNIA, 36., Porto Alegre, 1999. Anais. Porto Alegre:SBZ, 1999.

MALAFAIA, P.A.M.; VALADARES FILHO, S.C.; VIEIRA, R.A.M.; COELHO DA SILVA, J.F.; PEREIRA, J.C. Determinação da cinética ruminal das frações protéicas de alguns alimentos para ruminantes. Revista Brasileira de Zootecnia, v.26, n.6, p.1243 - 1251, 1997.

McDONALD, I. A revised model for the estimation of protein degradability in the rumen. Journal Agricultural Science, v.96, n.1, p.251-252, 1981. 
MEHREZ, A.Z.; ORSKOV, E.R. A study of the artificial fiber bag technique for determining the digestibility of feeds in the rumen. Journal Agricultural Science, v.88, p.645 - 650, 1977.

MERCHEN, N.R.; BOURQUIN, L.D. Processes of digestion and factors influencing digestion of forage-based diets by ruminants. In: FAHEY, G. C. JR.; COLLINS, M.; MERTENS, D.R.; MOSER, L.E. (Ed.). Forage quality, evaluation and utilization. Madison: ASA; CSSA; SSSA, 1994. cap.14, p.564 - 612.

MERTENS, D.R.; ELY, L.O. Relationship of rate and extent of digestion to forage utilisation- a dynamic model evaluation. Journal of Animal Science, v.54, p.895905, 1982.

MERTENS, D.R. NDF:Fiber composition and value of forages with different NDF concentrations. In: SOUTHWEST NUTRITIONAL ECOLOGY MAGENAMENT. Poenix: Arizona State University, 1998. p.85-99.

MERTENS, D.R. Regulation of forage intake. In: FAHEY, G.C.JR.; COLLINS, M.; MERTENS, D.R.; MOSER, L.E. (Ed). Forage quality, evaluation and utilization. Madison: ASA; CSSA; SSSA, 1994, cap.11, p.450 - 493.

MESSMAN, M.A.; WEISS, W.P.; ERICKSON, D.O. Effects of nitogen fertilization and maturity of bromegrass on in situ ruminal digestion kinetics of fiber. Journal of Animal Science, v.69, p.1151 - 1161, 1991.

MITCHELL, R.J.; HODGSON, J.; CLARK, D.A. The independence effects of sward height and bulk density on the bite parameters of Romney ewes and red deer hinds. In: INTERNATIONAL GRASSLAND CONGRESS, 17., Queensland, 1993. Proceedings. Queensland: Massey University, 1993. p.704 - 706. 
MOLAN, L.K.; ROSSETO, F.A.A.; NUSSIO, L.G.; SILVA, S.C.; PEDREIRA, C.G.S. Avaliação do valor nutritivo em diferentes estratos de plantas de capim-elefante (Pennisetum purpureum Schum.) e capim Tanzânia (Panicum maximum Jacq.) sob pastejo. In: SIMPÓSIO DE INICIAÇÃO CIENTÍFICA DA UNIVERSIDADE DE SÃO PAULO, 7., São Paulo, 1999. Resumos. São Paulo: USP, 1999. v.1, p.378.

NATIONAL RESEARCH COUNSIL. Nutrient requirements of domestics animals: nutrient requirements of dairy cattle. Washington: National Academy Science. 1990. $157 \mathrm{p}$.

NATIONAL RESEARCH COUNSIL. Nutrient requirements of domestics animals: nutrient requirements of beef cattle. Washington: National Academy Science. 1996. $245 p$.

NOCEK, J.F. Evaluation of specific variables affecting in situ estimates of ruminal dry matter and protein digestion. Journal of Animal Science, v.60, p.1347 - 1358, 1988.

ORSKOV, E.R.; McDONALD, I. The estimation of protein degradability in the rumen from incubation measurements weighted according to rate of passage. Journal of Agricultural Science, v.92, p.499 - 503, 1979.

OWENS, F.N.; ZINN, R. Protein metabolism of ruminant animals. In: CHURCH, D.C. (Ed.). The ruminant animal, digestive physiology and nutrition. Englewood Cliffs: Prentice-Hall, 1988. cap.12, p.227-249.

PACIULLO, D.S.C.; MATTOS, J.L.S.; GOMIDE, J.A.; QUEIROZ, D.S.; SILVA, E.A.M. da. Proporção de tecidos espessura da parede celular em espécies de braquiária, cultivadas sob diferentes níveis de umidade do solo (compact disc). In: REUNIÃO ANUAL DA SOCIEDADE BRASILEIRA DE ZOOTECNIA, 37., Porto Alegre, 1999. Anais. Porto Alegre: SBZ, 1999. 
PARSONS, A.J.; JOHNSON, J.R.; HARVEY, A. Use of a model to optimize the interaction between frequency and severity of intermittent defoliation and to provide a fundamental comparison of the continuous and intermittent defoliation of grass. Grass and Forage Science, v.43, p.49-59, 1988.

PATERSON, J.A.; BELYEA, R.L.; BOWMAN, J.P.; KERLEY, M.S.; WILLIAMS, J.E.. In: FAHEY, G.C. JR.; COLLINS, M.; MERTENS, D.R.; MOSER, L.E. (Ed.). Forage quality, evaluation and utilization. Madison: ASA; CSSA; SSSA, 1994. cap. 2, p.59- 113.

PEDREIRA, C.G.S.; MELLO, A.C.L. de. Cynodon spp. In: SIMPÓSIO SOBRE MANEJO DA PASTAGEM, 17., Piracicaba, 2000. A planta forrageira no sistema de produção. Piracicaba: FEALQ, 2000. p.109 - 134.

POPPI, D.P.; McLENNAN, S.R. Protein and energy utilization by ruminants at pasture. Journal of Animal Science, v.73, p.278-290, 1995.

POPPI, D.P.; CRUICKSHANK, G.J.; SYKES, A.R. Fish meal and amino acid supplementation of early weaned lambs grazing Roa tall fescue or Huia white clover. Animal Production, v.46, p.491, 1988.

REGO, F.C.A.; CECATO, U.; CANTO, M.W.; MARTINS, E.N.; MIRA, R.; SANTOS, G.T.; CANO, C.P. Qualidade do capim tanzânia (Panicum maximum Jacq. cv. Tanzânia-1) manejado em diferentes alturas, sob pastejo. In: REUNIÃO ANUAL DA SOCIEDADE BRASILEIRA DE ZOOTECNIA, 38., Piracicaba, 2001. Anais. Piracicaba: SBZ, 2001. p.117-118. 
RIBEIRO, G.K.; PEREIRA, O.G.; VALADARES FILHO, S.C.; GARCIA， R.; CABRAL, L.S. Caracterização das frações que constituem as proteínas e os carboidratos, e respectivas taxas de digestão, do feno de Capim-Tifton 85 de diferentes idades de rebrota. Revista Brasileira de Zootecnia, v.30, n.2, p.589 595, 2001.

RUIZ, T.M.; BERNAL, E.; STAPLES, C.R.; SOLLENBERGER, L.E.; GALLAHER, R.N. Effect of dairy neutral detergent fiber concentration and forage source on performance of lactating cows. Journal of Animal Science, v.70, p.305 - 319, 1995.

RUSSEL, J.B.; O'CONNOR, J.D.; FOX, D.G.; VAN SOEST, P.J.; SNIFFEN, C.J. A net carbohydrate and protein system for evaluating cattle diets: I. Ruminal fermentation. Journal of Animal Science, v.70, p.3551-3561, 1992.

SANTOS, P.M. Estudo de algumas características agronômicas de Panicum maximum (Jacq.) cvs. Tanzânia e Mombaça para estabelecer seu manejo. Piracicaba, 1997. 62p. Dissertação (Mestrado) - Escola Superior de Agricultura "Luiz de Queiroz", Universidade de São Paulo.

SANTOS, P.M.; BALSALOBRE, M.A.A.; CORSI, M. Efeito da freqüência de pastejo e da época do ano sobre a produção e a qualidade em Panicum maximum cvs. Tanzânia e Mombaça. Revista Brasileira de Zootecnia, v.28, p.244-249, 1999.

SANTOS, P.M.; BALSALOBRE, M.A.A.; CORSI, M. Participação de gerações de perfilhos na produção do capim Tanzânia. In: REUNIÃO ANUAL DA SOCIEDADE BRASILEIRA DE ZOOTECNIA, 38., Piracicaba, 2001. Anais. Piracicaba: SBZ, 2001. p.123 - 124 .

S.A.S. INSTITUTE. SAS User's guide : statistics. Cary: SAS Institute, 1990. 956p. 
SHENK, J.S.; WESTERHOUS, M.O. Population definition, sample selection, and calibration procedures for near infrared reflectance spectroscopy. Crop Science, v.31, p.469-474, 1991.

SILVA, D.S. da. Efeito da Pressão de pastejo sobre a estrutura, a produtividade e persistência do capim elefante anão (Pennisetum purpureum Schum, cv. Mott). Viçosa, 1993. 88p. Tese (Doutorado) -Universidade Federal de Viçosa.

SNNIFEN, C.J.; O'CONNOR, J.D.; VAN SOEST, P.J.; FOX, D.G.; RUSSELL, J.B. A net carbohydrate and protein system for evaluating cattle diets: II. Carbohydrate and protein availability. Journal of Animal Science, v.70, p.3562 - 3577, 1992.

STOBBS, T.H. The effect of plant structure on the intake of tropical pastures. Variation in the bite size of grazing cattle. Australian Journal of Agriculture Research, v.24, p.809 - 819, 1973.

TAIZ, L.; ZEIGER, E. Plant physiology. Redwood: The Benjamin/Cummings, 1991. $565 \mathrm{p}$.

THIAGO, L.R.L.S.; GILL, M. Consumo voluntário de forragem por ruminantes: mecanismo físico ou fisiológico? In: REUNIÃO ANUAL DA SOCIEDADE BRASILEIRA DE ZOOTECNIA, 38., Campinas, 1990. Anais. Campinas:SBZ, 1990. p. $853-871$.

TRAXLER, M.J.; FOX, D.G.;VAN SOEST, P.J.; PELL, A.N.; LASCANO, C.E.; LANNA, D.P.D.; MOORE, J.E.; LANA, R.P.; VÉLESZ, M.; FLORES, A. Predicting forage indigestible NDF from lignina concentration. Journal of Animal Science, v.76, p.1469 - 1480, 1998. 
TWIDWELL, E.K.; JOHNSON, K.D.; CHERNEY, J.H.; VOLENEC, J.J. Forage quality and digestion kinetics of Switchgrass herbage and morphological components. Crop Science, v.28, p.778 - 782, 1988.

VAN SOEST, P.J. Nutritional ecology of the ruminant. Ithaca: Cornell University press, 1982. 374p.

VAN SOEST, P.J.; ROBERTSON, J.B.; LEWIS, B.A. Methods for dietary fiber, neutral detergent fiber and nostarch polysaccharides in relation to animal nutrition. Journal of Dairy Science, v.74, p.3583 - 3597, 1991.

VIEIRA, R.A.M.; PEREIRA, J.C.; MALAFAIA, P.A.M. Fracionamento e cinética de degradação in vitro dos compostos nitrogenados da extrusa de bovinos a pasto. Revista Brasileira de Zootecnia, v.29, n.3, p.880 - 888, 2000a.

VIEIRA, R.A.M.; PEREIRA, J.C.; MALAFAIA, P.A.M. Fracionamento dos carboidratos e cinética de degradação in vitro da fibra em detergente neutro da extrusa de bovinos a pasto. Revista Brasileira de Zootecnia, v.29, n.3, p.889 - 897, $2000 b$.

VIEIRA, R.A.M.; PEREIRA, J.C.; MALAFAIA, P.A.M.; QUEIROZ, A.C de. Application of non-linear models in the description of in situ degradation profiles of the elephant grass (Pennisetm purpureum Schum., Mineiro variety). Animal Feed Science and Technology, v.66, p.197 - 210, 1997.

VOUGH, L.R.; MARTEN, G.C. Influence of soil moisture and and ambient temperature on yield and quality of alfalfa forage. Agronomy Journal, v.63, p.40 42, 1971. 
WEISS, W.P. Predicting energy values of feeds. Journal of Dairy Science, v.76, p.1802 - 1811, 1993.

WILSON, J.R.; MERTENS, D.R. Cell wall accessibility and cell structure limitations to microbial digestion of forage. Crop Science, v.35, n.1, p.251 - 259, 1995. 